I N T ER N ATIONAL MONETARY FUND

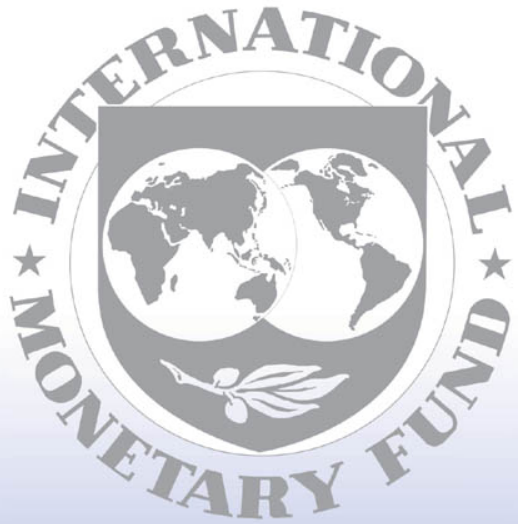

Staff

Country

Reports 


\title{
New Zealand: 2010 Article IV Consultation-Staff Report; and Public Information Notice on the Executive Board Discussion
}

Under Article IV of the IMF's Articles of Agreement, the IMF holds bilateral discussions with members, usually every year. In the context of the 2010 Article IV consultation with New Zealand, the following documents have been released and are included in this package:

- The staff report for the 2010 Article IV consultation, prepared by a staff team of the IMF, following discussions that ended on March 29, 2010, with the officials of New Zealand on economic developments and policies. Based on information available at the time of these discussions, the staff report was completed on April 27, 2010. The views expressed in the staff report are those of the staff team and do not necessarily reflect the views of the Executive Board of the IMF.

- $\quad$ A Public Information Notice (PIN) summarizing the views of the Executive Board as expressed during its May 12, 2010 discussion of the staff report that concluded the Article IV consultation.

The document listed below has been or will be separately released.

\section{Selected Issues Paper}

The policy of publication of staff reports and other documents allows for the deletion of market-sensitive information.

\author{
Copies of this report are available to the public from \\ International Monetary Fund $\bullet$ Publication Services \\ $70019^{\text {th }}$ Street, N.W. • Washington, D.C. 20431 \\ Telephone: (202) 623-7430 • Telefax: (202) 623-7201 \\ E-mail: publications@imf.org Internet: http://www.imf.org
}

\section{International Monetary Fund Washington, D.C.}




\title{
INTERNATIONAL MONETARY FUND
}

\author{
NEW ZEALAND
}

\section{Staff Report for the 2010 Article IV Consultation}

Prepared by the Staff Representatives for the 2010 Consultation with New Zealand (In consultation with other departments)

Approved by Mahmood Pradhan and Martin Mühleisen

April 27, 2010

- Discussions: March 19-29, 2010, with Minister of Finance Bill English, Governor of the Reserve Bank Alan Bollard, Treasury Secretary John Whitehead, and other senior officials and representatives of the private sector and trade unions.

- Team: Mr. Brooks (head), Mr. Schule, Mr. Jang, and Ms. Sun (all APD). Mr. di Maio (OED) also participated in the meetings.

- Focus: The macroeconomic policy mix to secure the recovery, reduce vulnerabilities, and preserve financial stability.

- Past Fund Advice: For a description of policy issues discussed in the 2009 Article IV consultation, see http://www.imf.org/external/pubs/cat/longres.cfm?sk=22933.0 and Appendix I.

- Exchange System: New Zealand has accepted the obligations of Article VIII, Sections 2,3 , and 4 . The exchange rate is free of restrictions on the making of payments and transfers for current international transactions other than restrictions notified to the Fund in accordance with Decision No. 144-(52/51). The de facto exchange rate arrangement is free floating.

- Official Development Assistance: 0.3 percent of national income for ODA in 2009/10, focused on the Pacific. 
Executive Summary

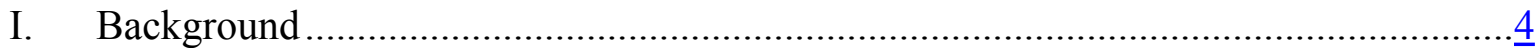

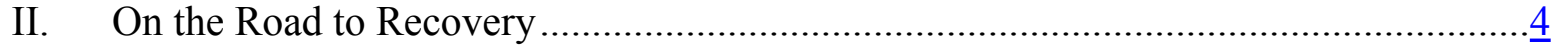

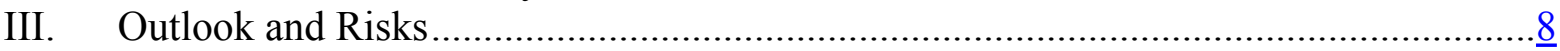

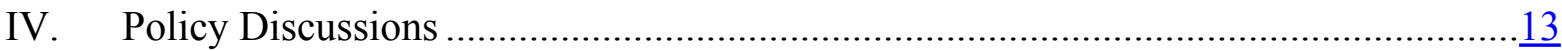

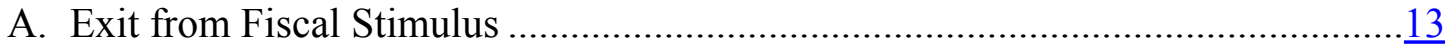

B. Exit from Monetary Stimulus ........................................................................

C. Maintaining Financial Sector Stability .......................................................

D. Addressing External Vulnerability and Increasing Saving ...................................21

E. Authorities' Views on Staff Advice..................................................................

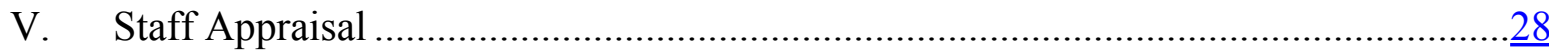

Boxes

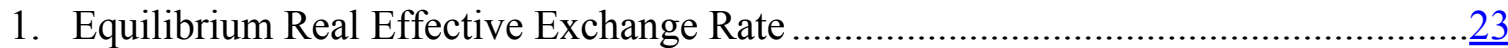

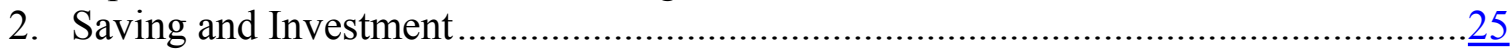

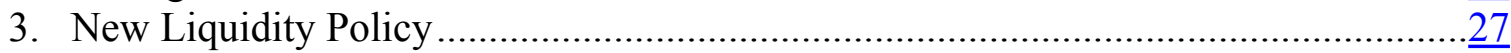

Figures

1. Recovery from Recession .................................................................................

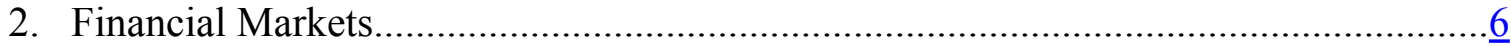

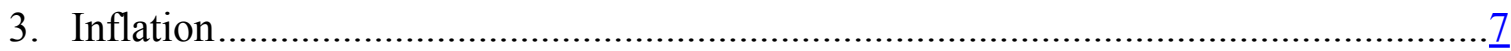

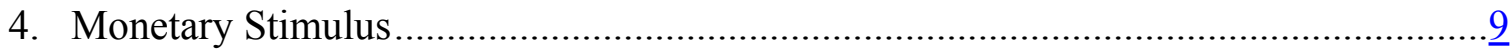

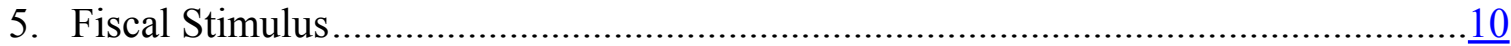

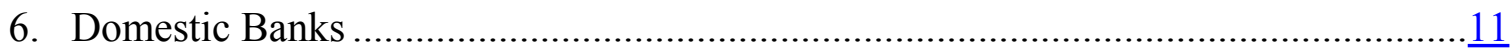

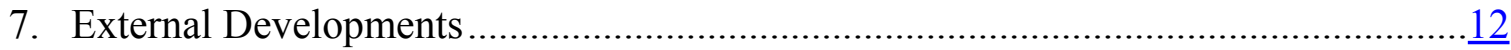

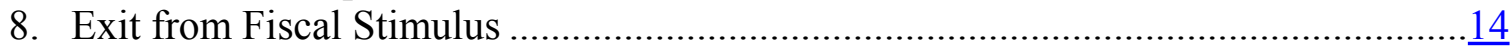

9. Comparison of Fiscal Outlook .......................................................................

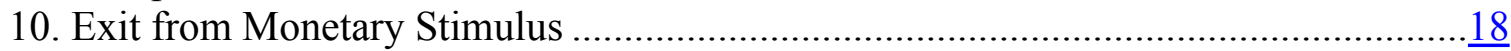

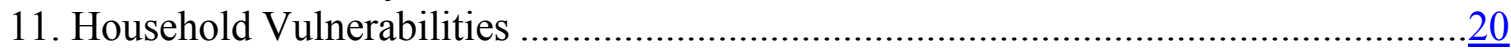

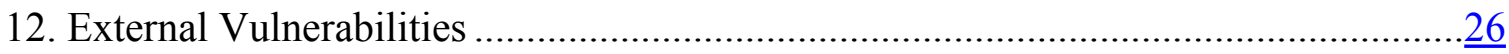

Tables

1. Selected Economic and Financial Indicators, 2005-11 ….........................................

2. Summary of Central Government Budget, 2006/07-2010/11 ..................................31

3. Balance of Payments and External Debt, 2004-10 ...................................................

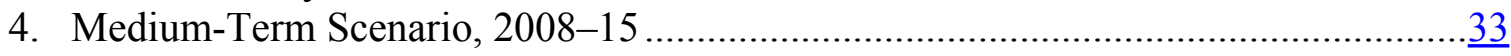

5. Unwinding Crisis-Related Monetary Policy Measures.................................................

Appendices

I. Main Recommendations of the 2009 Article IV Consultation ...................................

II. External Debt Sustainability: Bound Tests .............................................................. 


\section{EXECUTIVE SUMMARY}

New Zealand rode out the crisis better than most advanced economies and a gradual economic recovery is underway. The outlook, however, is subject to a number of downside risks mainly related to the pace of the global recovery. The authorities are more optimistic than staff concerning the near-term outlook, given the economy's growing links to Asia and Australia. Two key macro-financial vulnerabilities persist - high household debt and high external debt. The impairment of credit markets created some difficulties in rolling over shortterm external debt during the crisis.

The strong fiscal position prior to the global crisis enabled the authorities to deliver a sizable fiscal easing that helped cushion the impact of the crisis. However, the mediumterm fiscal outlook has worsened because income tax cuts and many of the spending initiatives were permanent and revenue projections have been revised down.

Staff welcomed the government's commitment to limit the increase in public debt, but advised faster consolidation. A shift in the macroeconomic policy mix toward faster fiscal consolidation would relieve pressure on monetary policy and thereby the exchange rate, and limit the increase in the current account deficit. Faster consolidation would also create fiscal space to deal with future shocks, and reduce the likelihood of an increase in the risk premium related to New Zealand's high external debt. The authorities had considered the merits of faster fiscal consolidation, but decided that their planned pace of consolidation was appropriate.

Staff noted that the current accommodative monetary stance is appropriate and the RBNZ should gradually return to a neutral stance once the recovery is well established. The inflation-targeting framework served New Zealand well during the global crisis and there are no clear net benefits to increasing the inflation target.

Banks remain sound, but staff advised continued vigilance as banks are exposed to households and house prices appear overvalued. Staff welcomed closer collaboration with Australian authorities on crisis management and stress tests, and recommended that banks' capital and provisioning be strengthened if these tests suggest the need for additional buffers.

While uncertain, staff estimates suggest that the exchange rate is overvalued by 10 25 percent. If this overvaluation proves to be temporary, it may limit the expected widening of the current account deficit. But even if the current account returns to the estimated norm of almost 5 percent of GDP, net foreign liabilities would remain high at 90 percent of GDP.

\section{Staff supported prudential and structural reforms that would help reduce external} vulnerability. The introduction of the prudential liquidity policy, including a core funding ratio, should reduce banks' reliance on short-term external funding. The core funding ratio could be raised further than planned if needed to help reduce short-term external debt. Structural reforms to raise productivity and labor force participation, including tax and benefit reforms, would lift potential growth and export capacity. 


\section{BACKGROUND}

1. New Zealand experienced a relatively shallow recession during 2008-09. The end of a housing boom in response to tight monetary policy slowed domestic demand, which combined with a drought pushed the economy into a recession in early 2008, ahead of many other countries. Subsequently, the downturn was exacerbated by the global financial crisis. Real GDP contracted by about $1 \frac{1}{2}$ percent in 2009, compared to an average contraction of 3 percent for other advanced economies.

\section{The global crisis has not hit New Zealand as hard as many other advanced} countries. This was because of demand from fast-growing Asian markets and the robust Australian economy, a flexible exchange rate, and the absence of a banking crisis (Figure 1). In addition, a sound macroeconomic framework and a strong pre-crisis fiscal position allowed significant monetary and fiscal policy easing that cushioned the blow from the global crisis. Nevertheless, the crisis highlighted long-standing vulnerabilities due to high household and high external debt.

\section{ON THE ROAD TO RECOVERY}

3. The economy emerged from the recession in mid-2009. Domestic demand is driving the recovery, supported by fiscal stimulus, low mortgage rates, and improved world commodity prices (Table 1). The unemployment rate (7.3 percent at end-2009) has not risen as sharply as elsewhere, which has helped underpin confidence.

\section{Financial markets have regained some lost ground, as global sentiment} improved and credit strains eased. Money market spreads and bank CDS spreads have declined sharply from crisis highs, but the stock market is still about 25 percent below the 2007 peak (Figure 2). Sovereign bond spreads remain about 70-80 basis points above the average of the past 15 years.

\section{The exchange rate depreciated sharply at the onset of the crisis, but has} appreciated since early 2009. In the year to February 2009, the nominal effective exchange rate depreciated by 30 percent, as the Reserve Bank of New Zealand (RBNZ) eased monetary policy and the global crisis hit commodity prices and heightened risk aversion. Since then, the nominal effective exchange rate has appreciated by about 20 percent, reflecting a recovery in commodity prices and global risk appetite, and a widening of interest rate differentials.

\section{Rising unemployment and a widening output gap contained growth in labor} costs and eased inflationary pressures (Figure 3 ). Headline and nontradables CPI inflation fell to about 2 percent $y / y$ in March 2010, consistent with the inflation target of 1-3 percent and well below the peaks of $4-5$ percent in 2008 . 
Figure 1. New Zealand: Recovery from Recession

The economy began to emerge from recession in 2009 Q2...

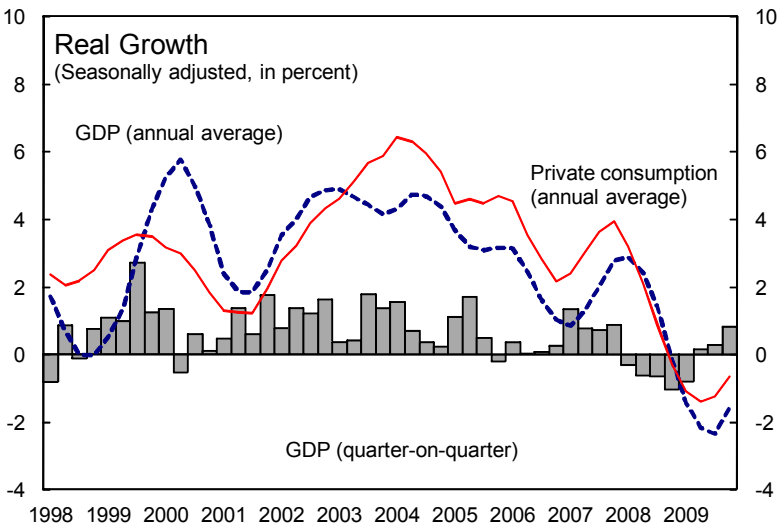

...and a relatively low share of high-tech manufacturing in GDP.

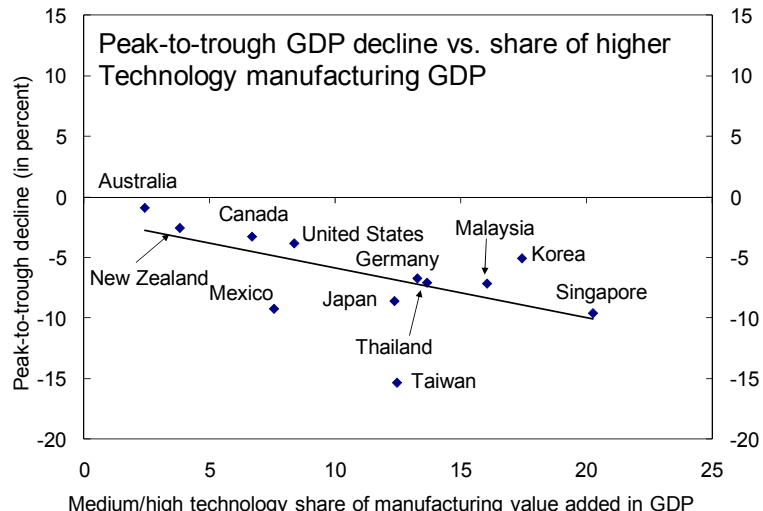

The recovery has been subdued so far, but near-term prospects are improving in line with global developments...

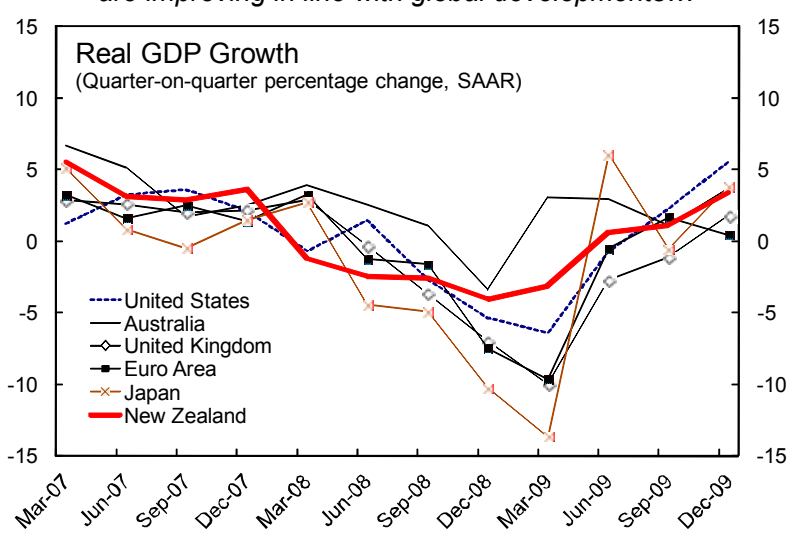

...helped by increasing ties with Australia and faster growing countries such as China...

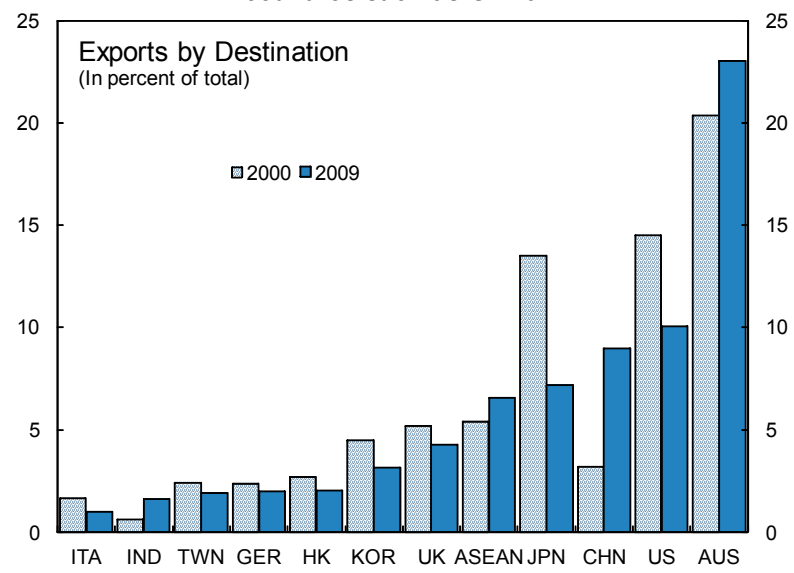

Consequently, the recession was not as severe as in many other countries.
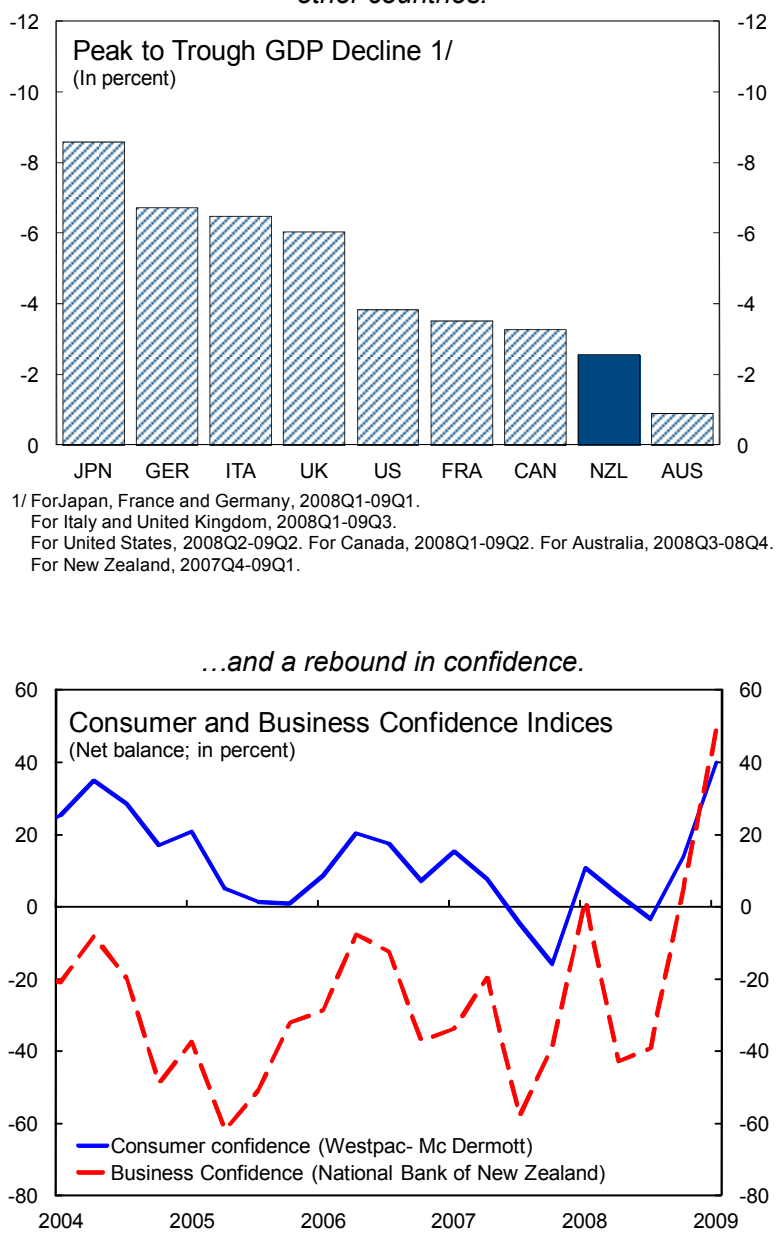

Sources: Statistics New Zealand; Reserve Bank of New Zealand; UNIDO database; Haver Analytics database; World Economic Outlook; and Fund staff estimates. 
Figure 2. New Zealand: Financial Markets

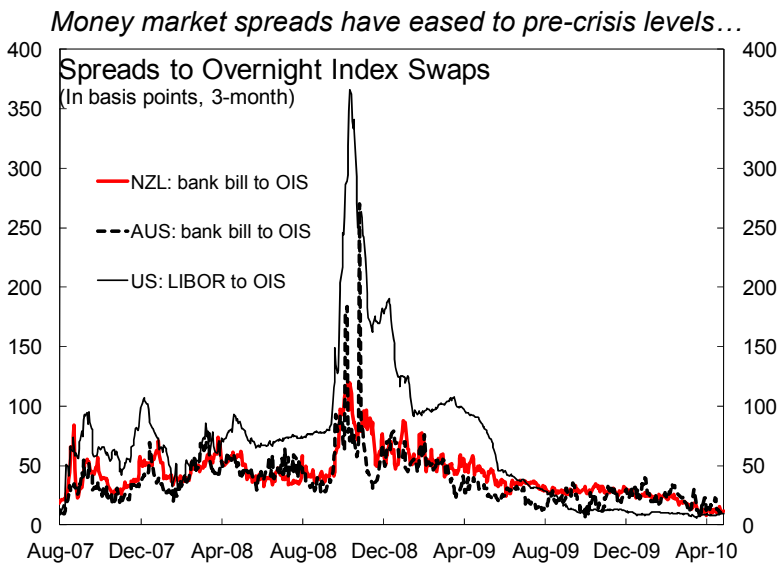

The exchange rate appreciated in the past year with the rise of commodity prices, widening interest differentials, ...

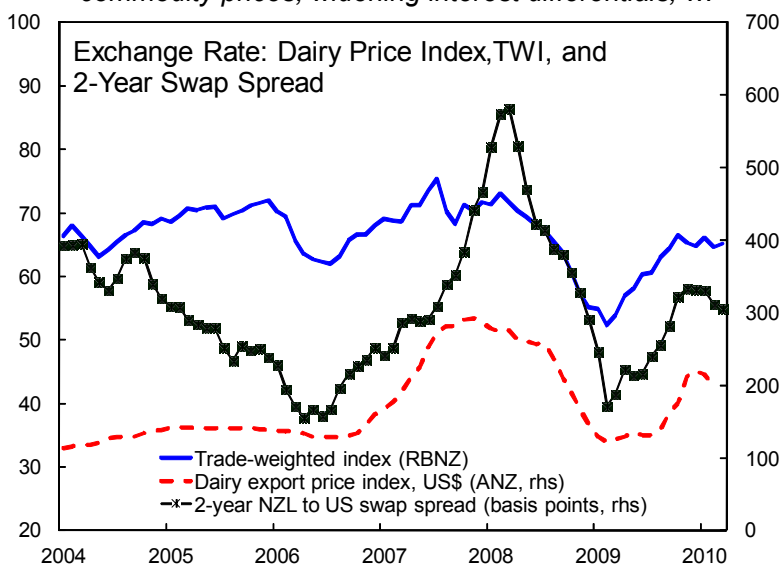

Spreads of government bonds eased somewhat, but remain

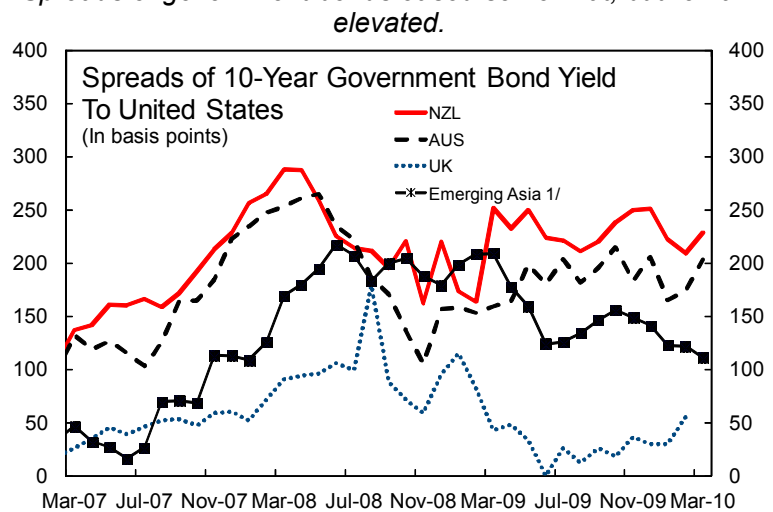

1/ Average for China,Hong Kong SAR, India, Indonesia, Korea, Malaysia, Philippines, Singapore,Taiwan Province of China, and Thailand.

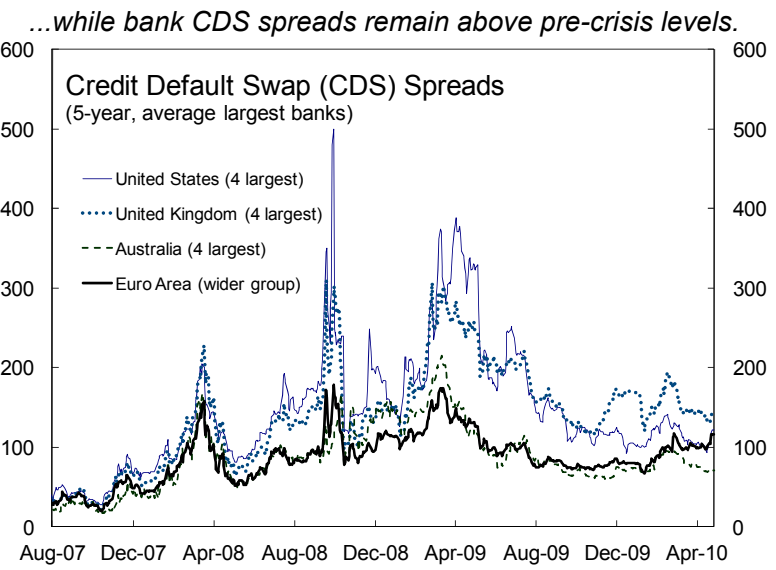

...and the return of risk appetite.

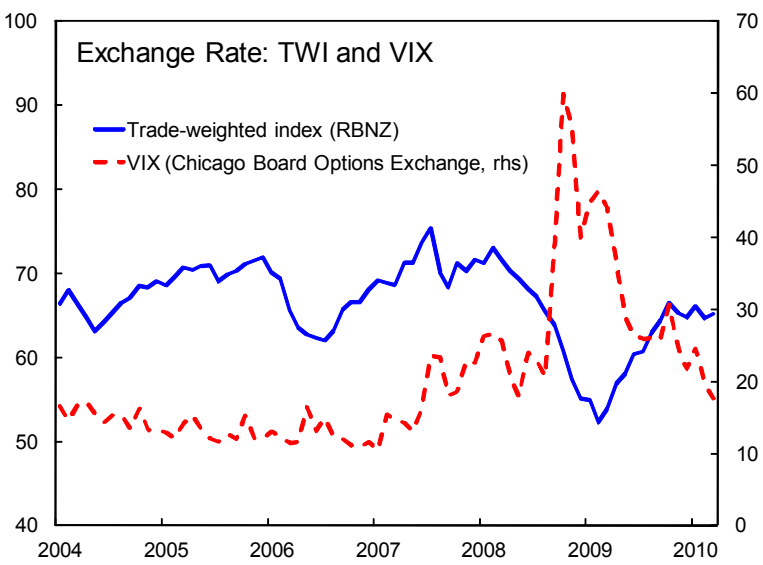

The stock market has recovered some lost ground.

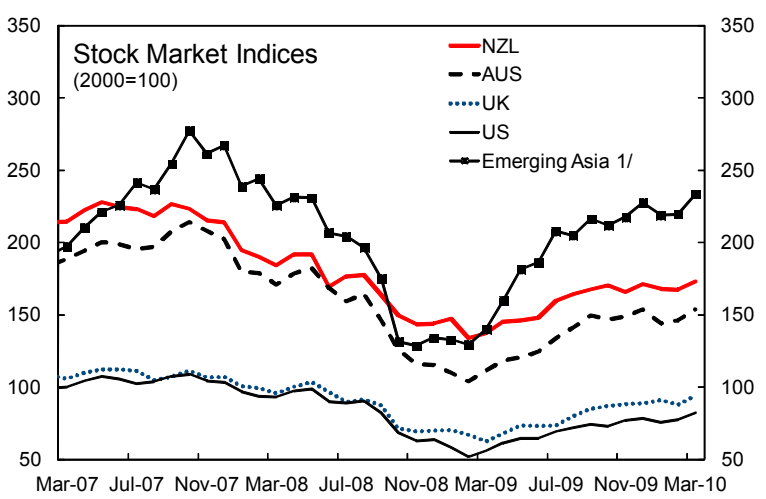

1/ Average for China,Hong Kong SAR, India, Indonesia, Korea, Malaysia, Philippines, Singapore, Taiwan Province of China, and Thailand.

Sources: Bloomberg; Haver Analytics database; International Financial Statistics database; APDCORE database; and Fund staff estimates. 
Figure 3. New Zealand: Inflation
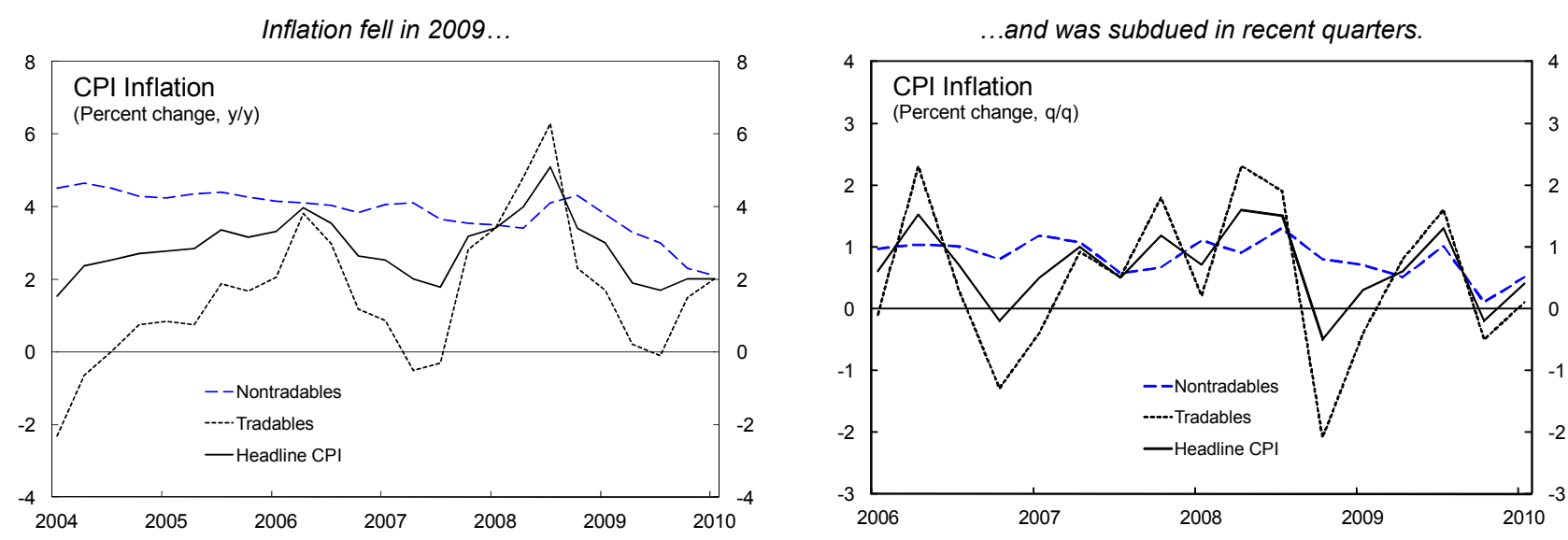

Rising unemployment and spare capacity...
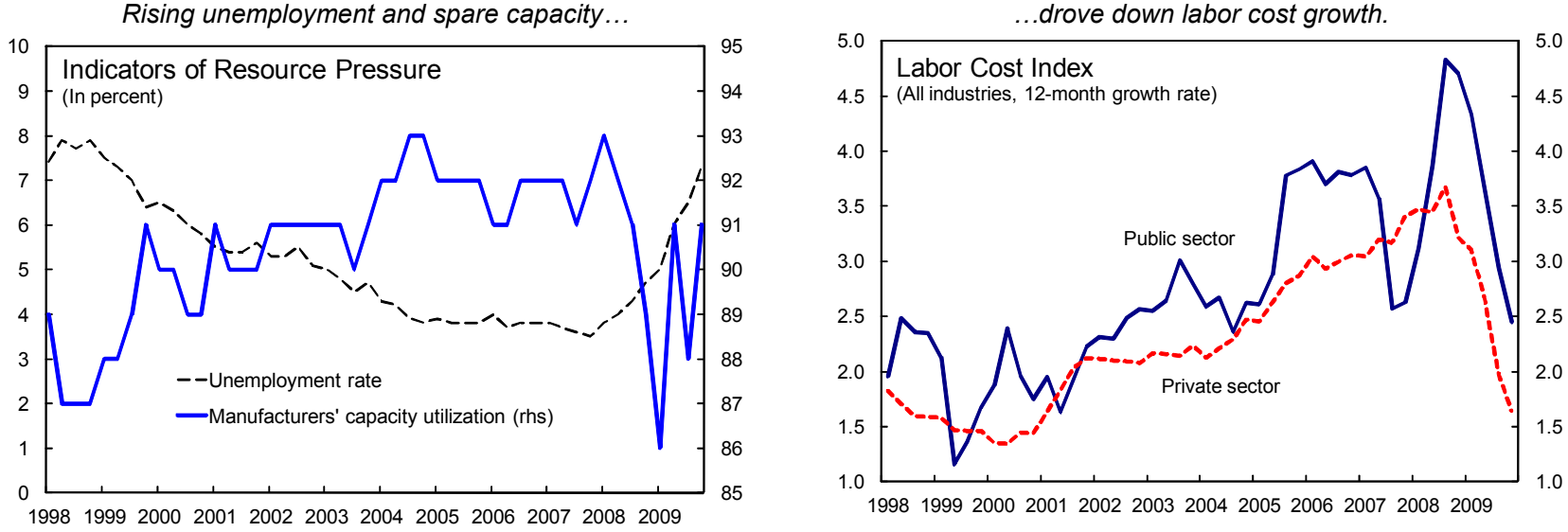

Economic slack remains significant.

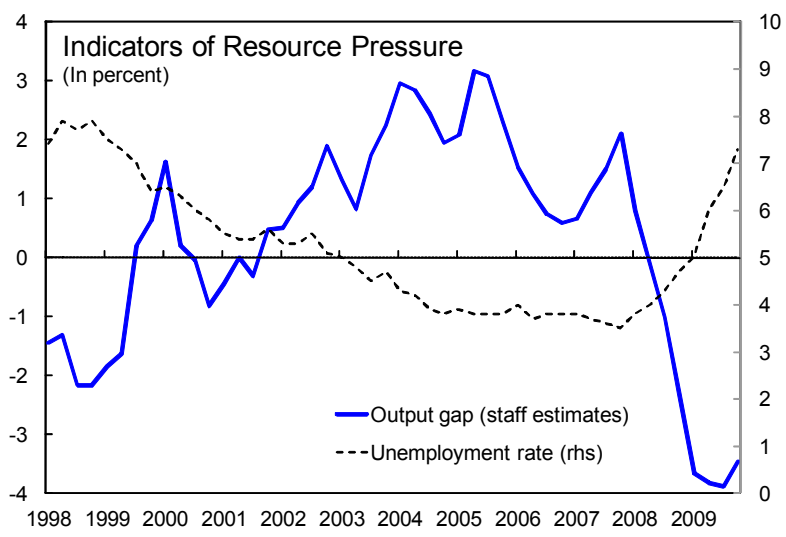

Inflation expectations are within the 1-3 percent inflation target band.

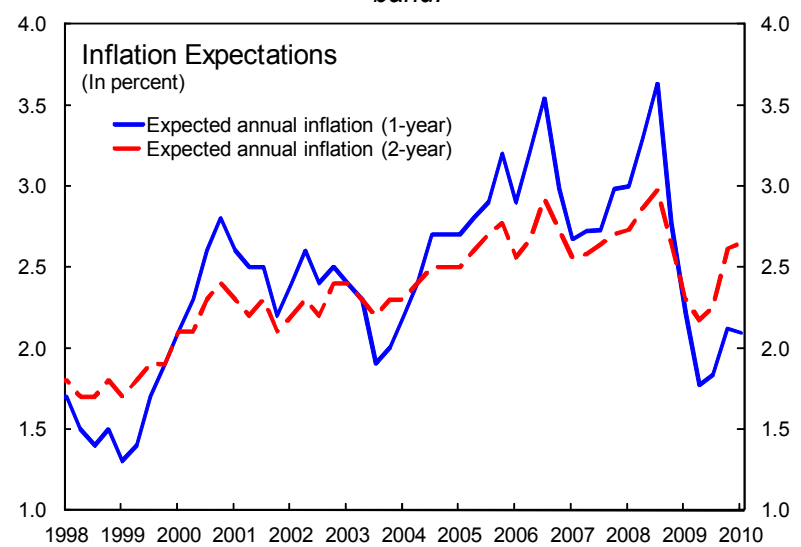

Sources: Reserve Bank of New Zealand; Statistics New Zealand; New Zealand Institute of Economic Research; Bloomberg; International Financial Statistics database. 
7. As the economic outlook weakened, the RBNZ cut its policy rate by 575 basis points from mid-2008 to early 2009 and then kept it at a historical low of $2 \frac{1}{2}$ percent (Figure 4). Unlike some other advanced economies, the transmission of monetary policy remained effective, and the aggressive cuts in the policy rate were largely, but not fully, reflected in lower lending rates, which supported domestic demand.

8. A sizable easing of fiscal policy also helped support activity. The fiscal position was strong before the crisis hit, with a string of surpluses reducing net public debt to 6 percent of GDP by mid-2008 (Table 2). This enabled the authotities to deliver a large fiscal stimulus, equivalent to almost 6 percent of GDP spread over the two years to June 2010 (Figure 5).

9. Banks remain sound but faced some funding difficulties during the crisis. Four large Australian-owned banks dominate the financial sector and suffered an increase in nonperforming loans to $1 \frac{1}{2}$ percent of total loans, though still low by advanced country standards (Figure 6). They increased provisioning and raised additional capital from their parents and through retained earnings. New Zealand subsidiaries faced more difficulties rolling over their sizable short-term funding than their Australian parents when international wholesale markets were severely impaired after the collapse of Lehmann Brothers. In response, the government introduced a wholesale funding guarantee that helped banks obtain term funding of about $\$ \mathrm{NZ} 10$ billion until they were able to access the market directly late last year.

10. The current account deficit narrowed sharply in 2009 to 3 percent of GDP, as both trade and income balances improved (Figure 7, Table 3). While imports dropped sharply due to the recession, primary exports benefited from fast growing Asia markets and manufacturing and service receipts were helped by robust Australian demand and a depreciation of the $\$ N Z / \$ A$ rate. In addition, lower interest and profit payments reduced the income deficit.

\section{OUTLOOK AND RISKS}

11. In the near-term, a gradual economic recovery is expected. Accommodative fiscal and monetary policies continue to support domestic demand and real GDP is projected to expand by about 3 percent in 2010 and 2011 . The unemployment rate is forecast to lag the recovery and peak at $71 / 2$ percent in 2010 .

\section{Over the medium term, growth is projected to fall back to staff's estimate of} potential of $2 \frac{1}{3}$ percent (Table 4 ). High household debt and an expected increase in the cost of capital as a result of the global crisis are likely to weigh on the growth of private consumption and investment. Under the baseline assumption of a constant real effective exchange rate (REER), the contribution of net exports to growth will remain muted. The income deficit is expected to worsen as interest rates and profits rise, leading to a widening of the current account deficit. 
Figure 4. New Zealand: Monetary Stimulus

The policy rate was cut aggressively...

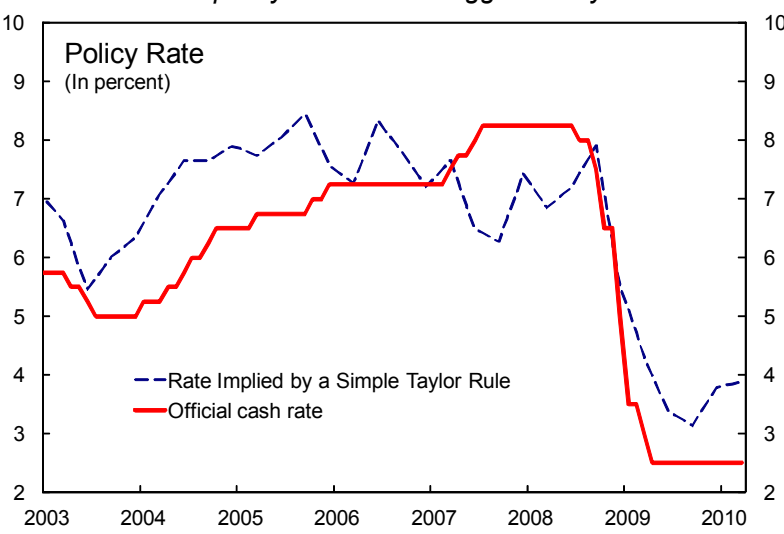

...more so than in the United States.

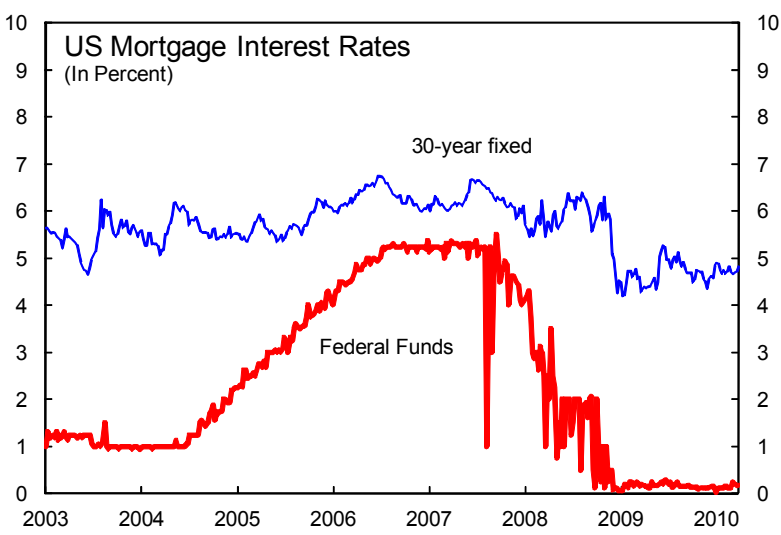

....and the spread between the OCR and banks' floating mortgage rates increased because of competition for deposits...

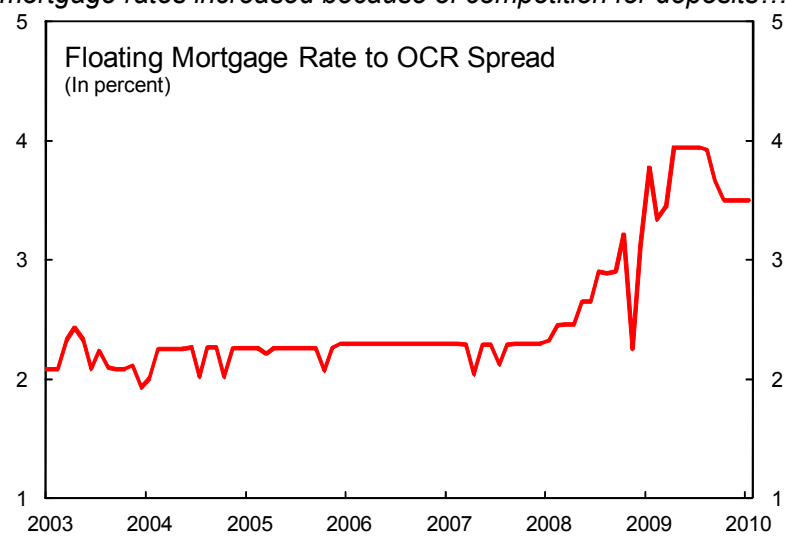

...and mortgage rates declined...

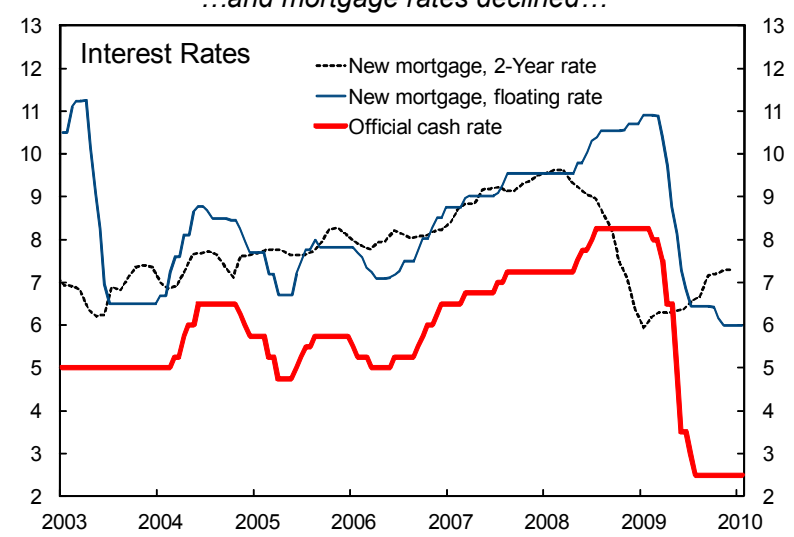

Effective lending rates fell, but not as much as the policy rate and the bank bill rate...

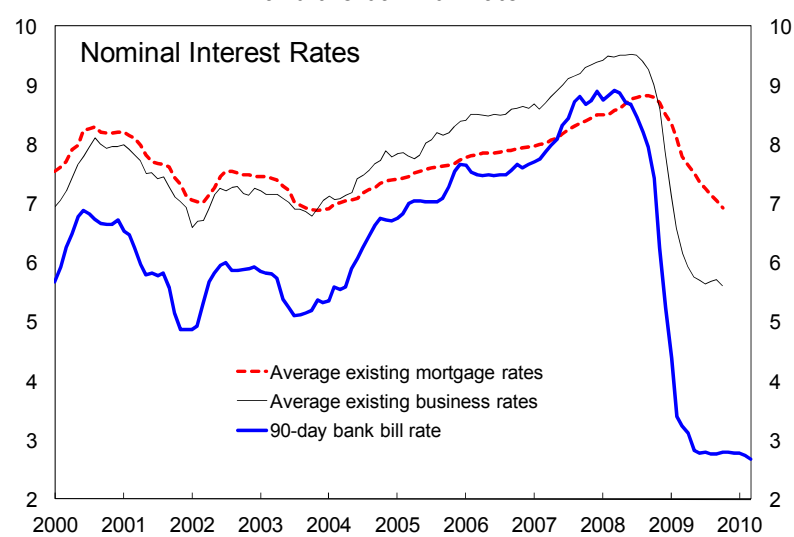

...and falling inflation kept real effective lending rates at a relatively high level.

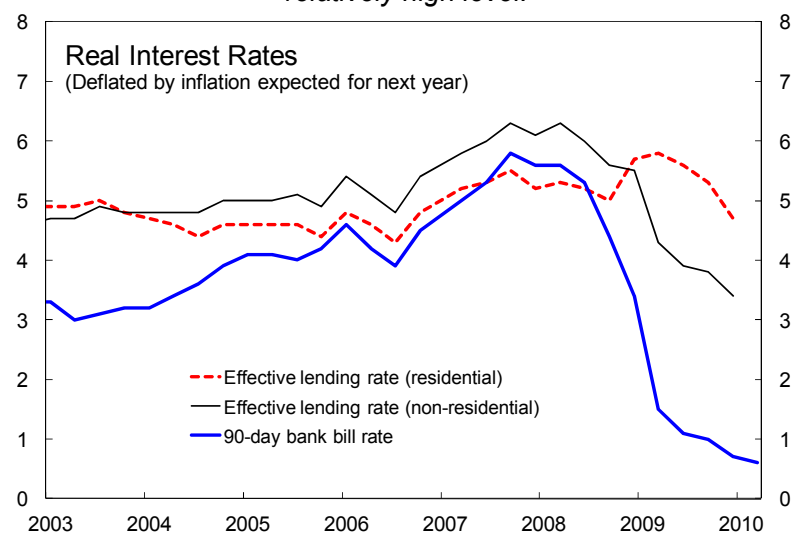

Sources: Reserve Bank of New Zealand; Statistics New Zealand; Bloomberg; International Financial Statistics database. 
Figure 5. New Zealand: Fiscal Stimulus

A sizable fiscal stimulus was delivered..

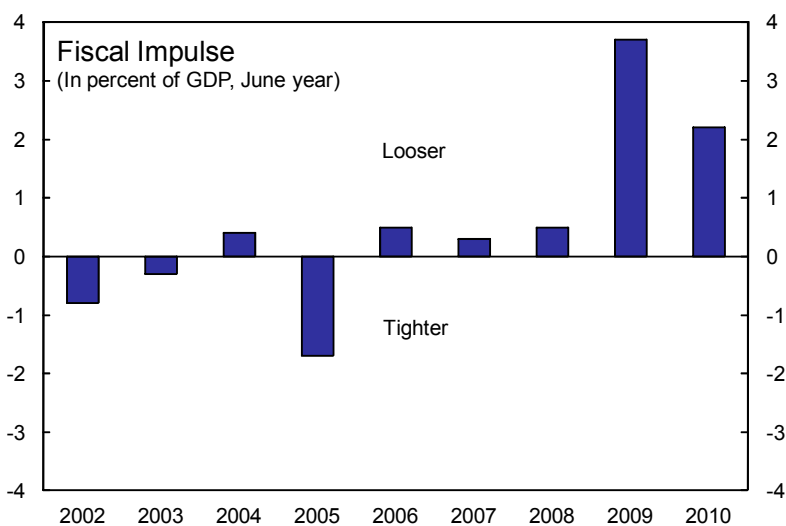

But tax receipts from individuals and corporates were also hit by the recession.

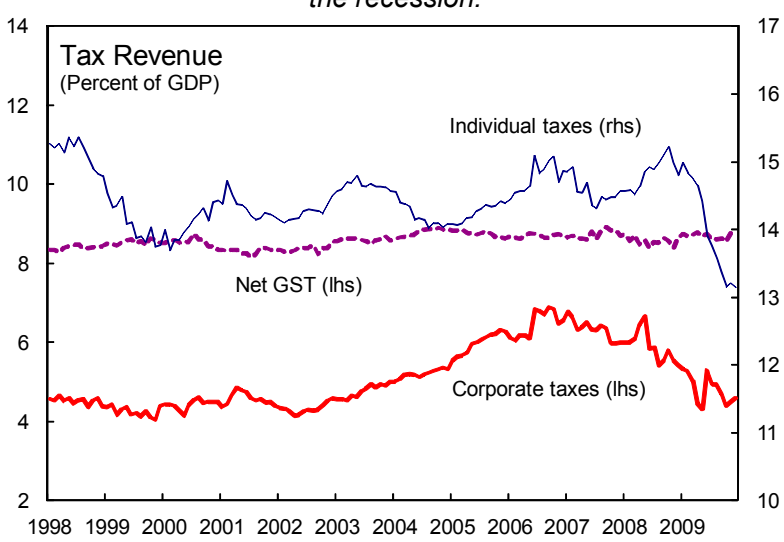

Low public debt allowed space for stimulus...

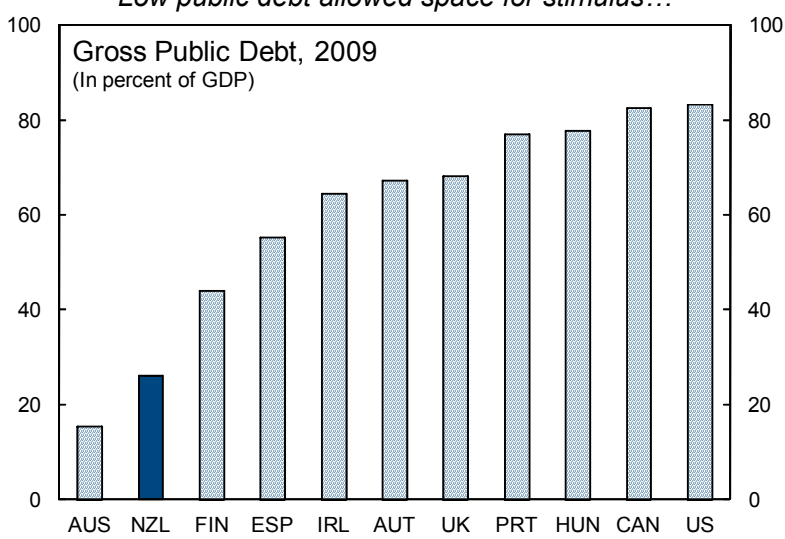

...through tax cuts and higher spending.

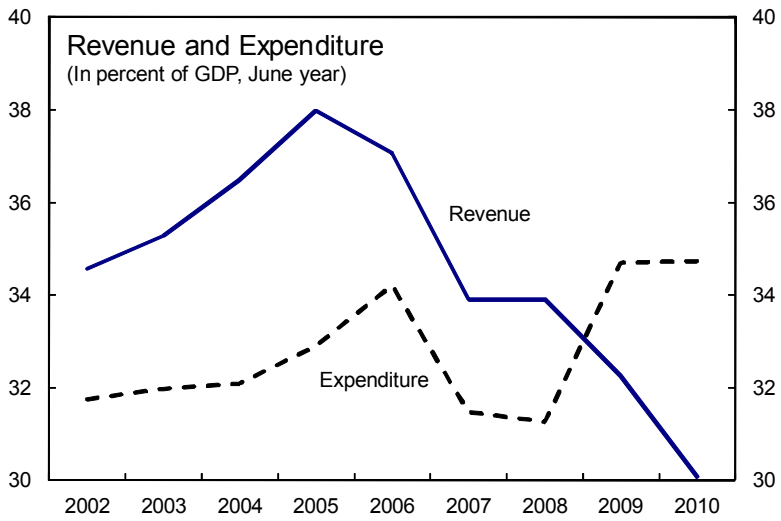

Fiscal deficits emerged, but are smaller than in many countries.
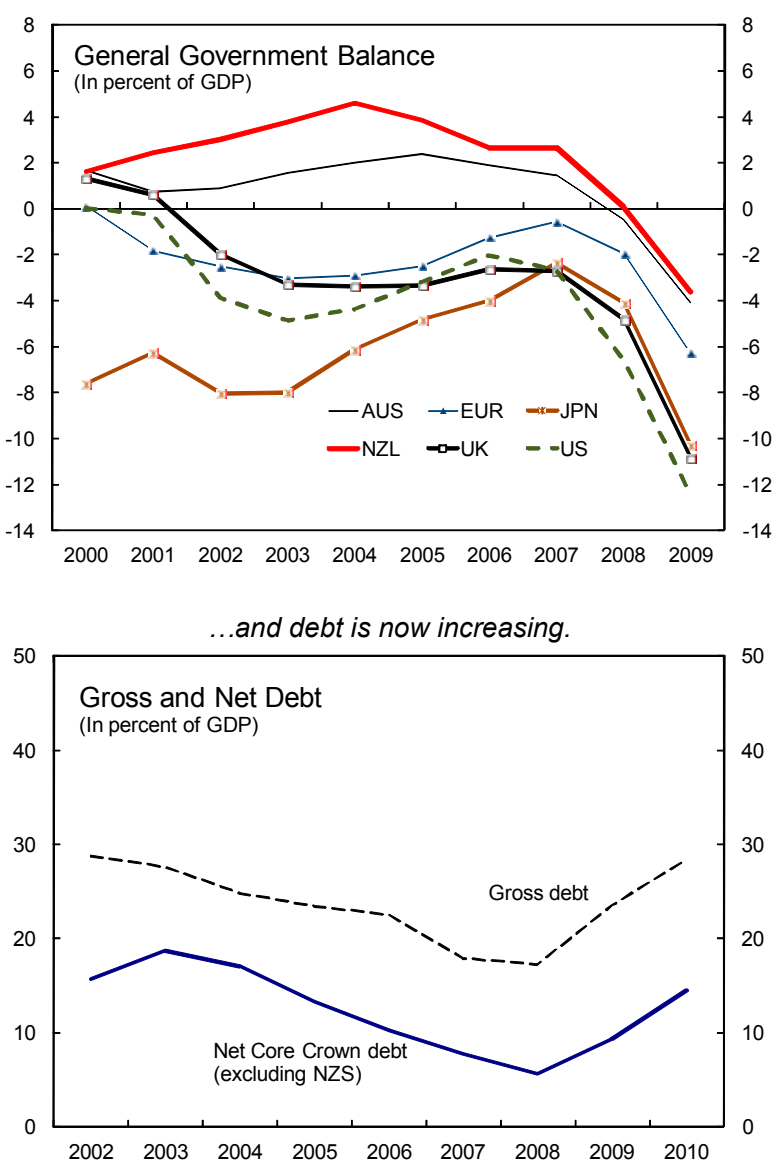

Note: Fiscal years ending June 30 .

Sources: The New Zealand Treasury; SNZ; World Economic Outlook; and Fund staff calculations and projections. 
Figure 6. New Zealand: Domestic Banks

Bank capital remains healthy...

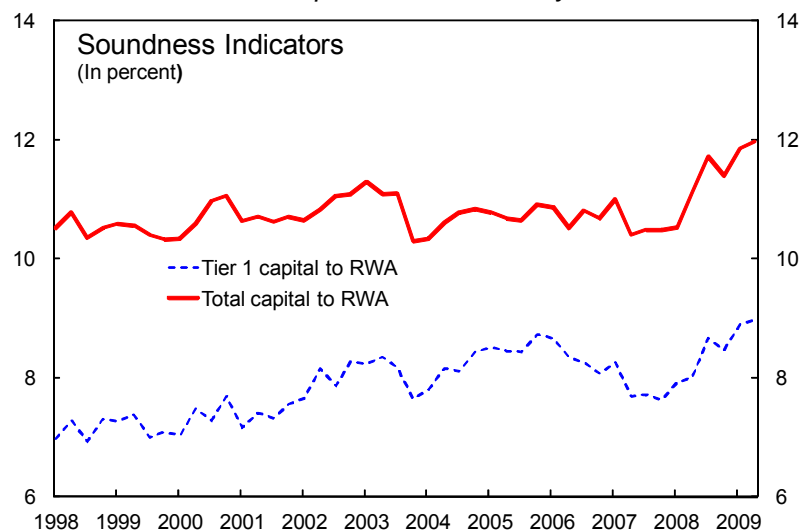

...although impaired loans are low by advanced economy standards.

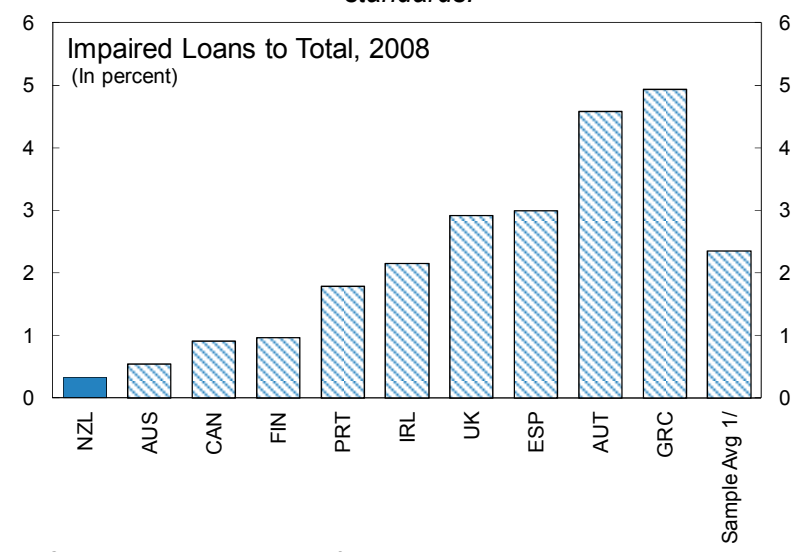

1/ Simple (unweighted) average of comparator countries, excluding New Zealand.

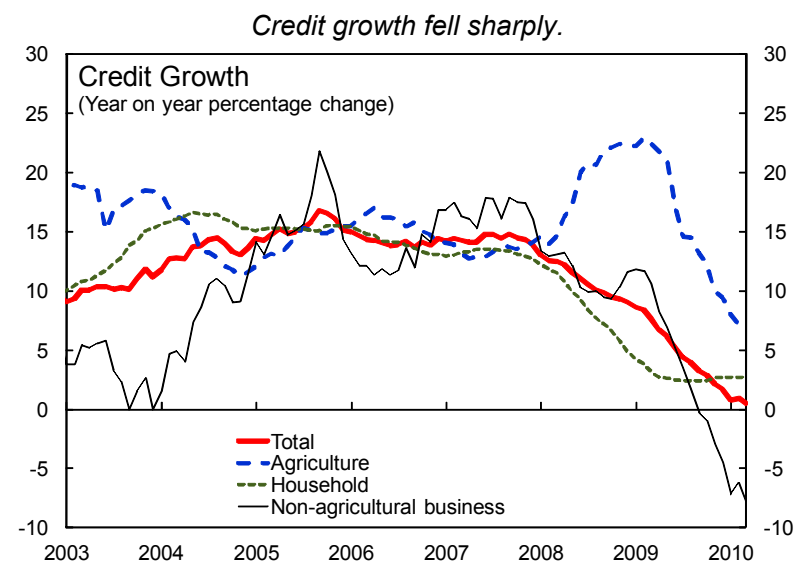

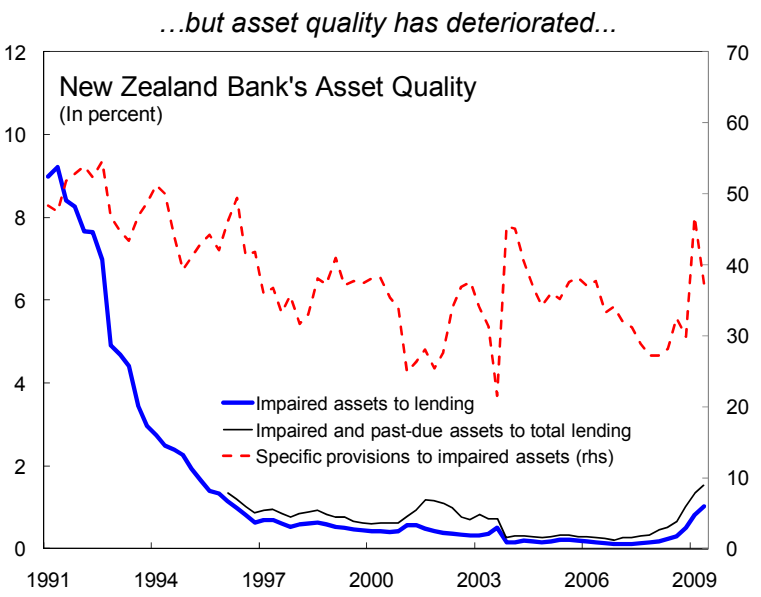

Bank share prices fell less than in some other countries.
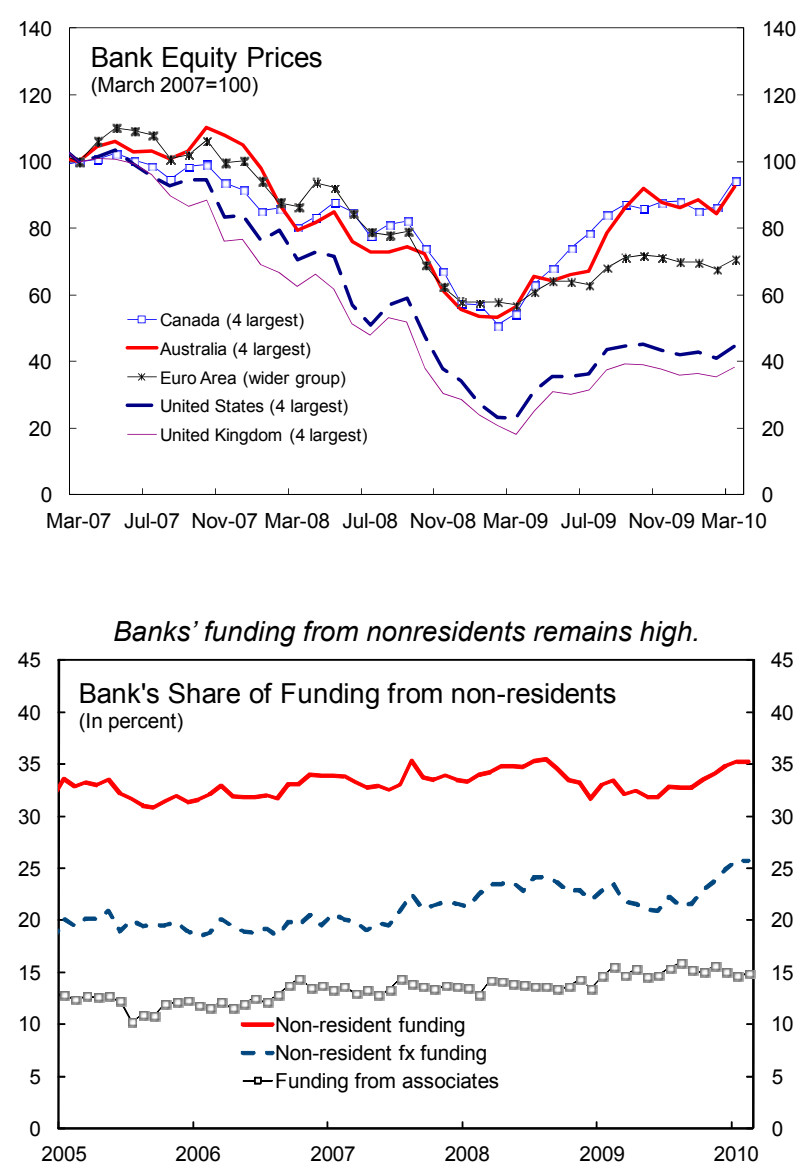

Sources: Reserve Bank of New Zealand; Bankscope; APRA; Haver Analytics database; and Fund staff estimates. 
Figure 7. New Zealand: External Developments

The current account deficit narrowed considerably in $2009 .$.

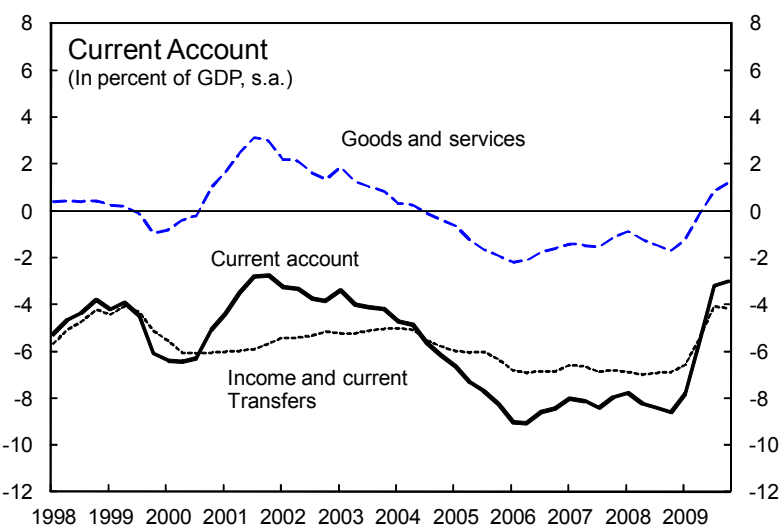

Export volumes held up relatively well....

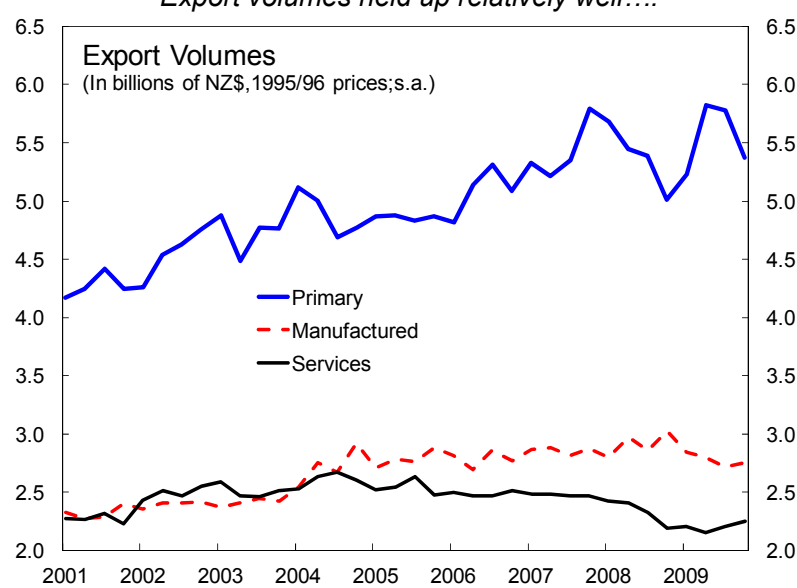

Debt inflows fell sharply while equity inflows improved...

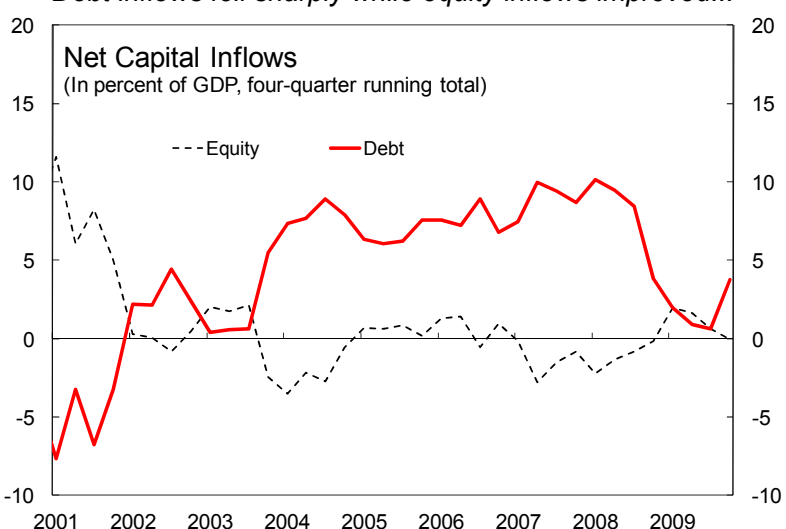

... with the trade balance shifting to surplus and income payments shrinking.

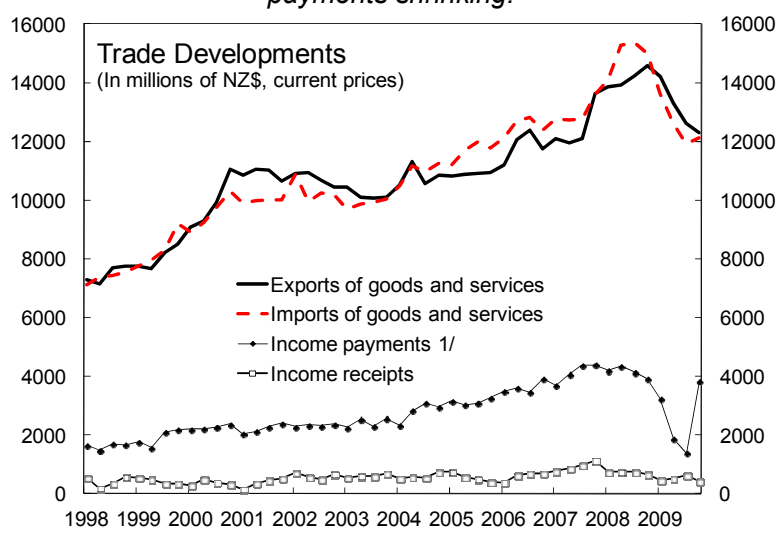

$1 /$ Including one-off tax transactions deduction of 2 billion (NZ\$) in 2009.
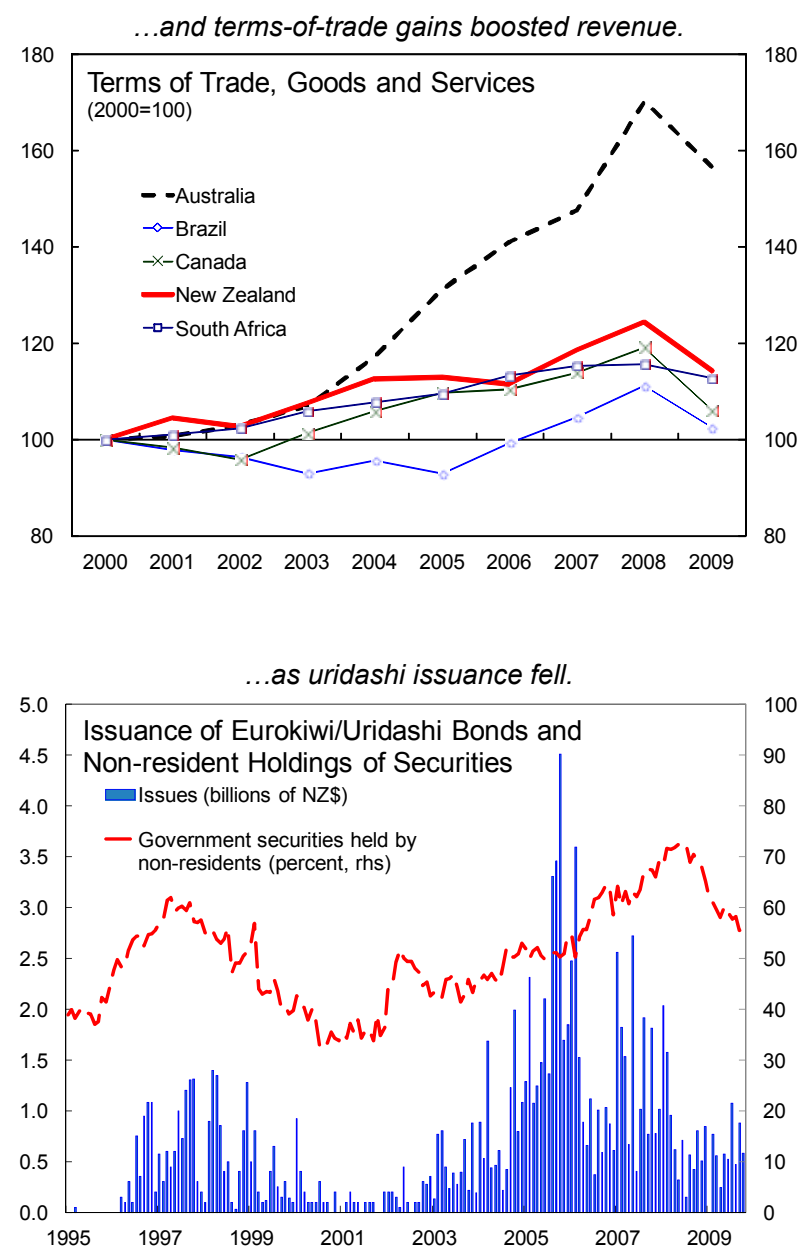

Sources: Reserve Bank of New Zealand; SNZ; Haver Analytics database; World Economic Outlook; International Financial Statistics database; and Fund staff estimates. 
13. On the external front, risks are tilted to the downside as global activity remains dependent on highly accommodative macroeconomic policies. The global recovery could stall and Chinese demand drop sharply, with negative spillovers for commodity prices. In addition, risk premiums could rise further for countries with high external debt, such as New Zealand, thereby constraining growth. However, an increase in global risk appetite is also possible, which may lead to a further appreciation of the exchange rate, making it difficult to rebalance growth toward the tradables sector.

14. On the domestic front, a stronger-than-expected recovery may force an earlier tightening in monetary policy, putting upward pressure on the exchange rate. However, faster-than-expected deleveraging by households and businesses may slow the recovery.

\section{Policy Discussions}

15. Discussions focused on the macroeconomic policy mix needed to rebalance the economy toward the tradable sector and increase saving to address the vulnerabilities associated with high household and external debt.

\section{A. Exit from Fiscal Stimulus}

16. The sizable fiscal easing in the past two years helped cushion the impact of the crisis, but worsened the medium-term fiscal outlook. Income tax cuts and many of the spending initiatives, taken before the crisis hit, were permanent and revenue projections have been revised down. As a result, budget deficits of about 2-4 percent of GDP on an accrual basis (operating balance before gains and losses) and 3-6 percent of GDP on a cash basis are projected over the next 4-5 years. ${ }^{1}$

\section{Staff supported the fiscal stimulus through June 2010 and the government's} long-term net public debt target of 20 percent of GDP. The large stimulus helped buffer the economy from the impact of the crisis while the commitment to contain the long-term increase in debt should ensure fiscal sustainability.

18. The government plans to reduce budget deficits gradually through expenditure restraint and fiscal drag, with a return to balance by 2016. A fiscal impulse of more than 2 percent of GDP is being implemented for 2009/10, with a further small impulse of $1 / 2$ percent of GDP planned for 2010/11 (Figure 8). On this basis, the authorities expect that net core crown debt would peak at 30 percent of GDP by 2016 and fall below 20 percent of GDP by 2024. While the stimulus was larger than in most advanced economies, the increase in public debt is expected to be smaller than average, as New Zealand had budget surpluses prior to the crisis (Figure 9).

\footnotetext{
${ }^{1}$ Cash deficits are larger partly because of a planned increase in capital spending, that is greater than depreciation included in the accrual measure of the deficit.
} 
Figure 8. New Zealand: Exit from Fiscal Stimulus

The fiscal impulse dissipates by $2011 \ldots$

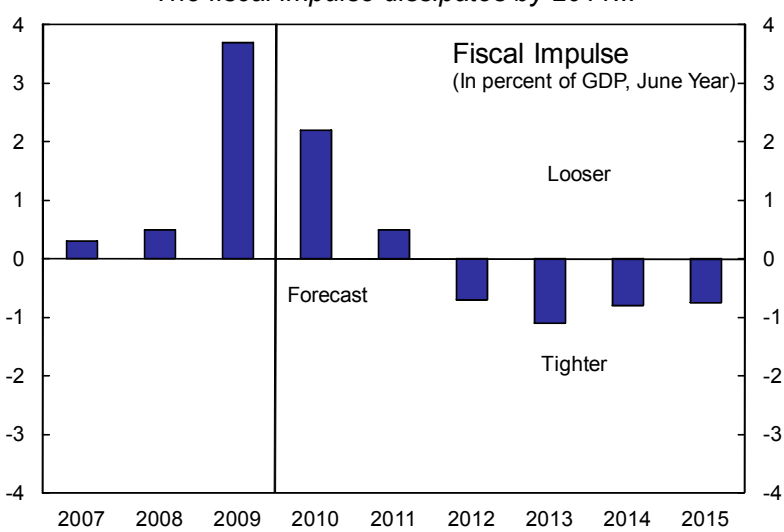

...mainly through control of spending and fiscal drag.

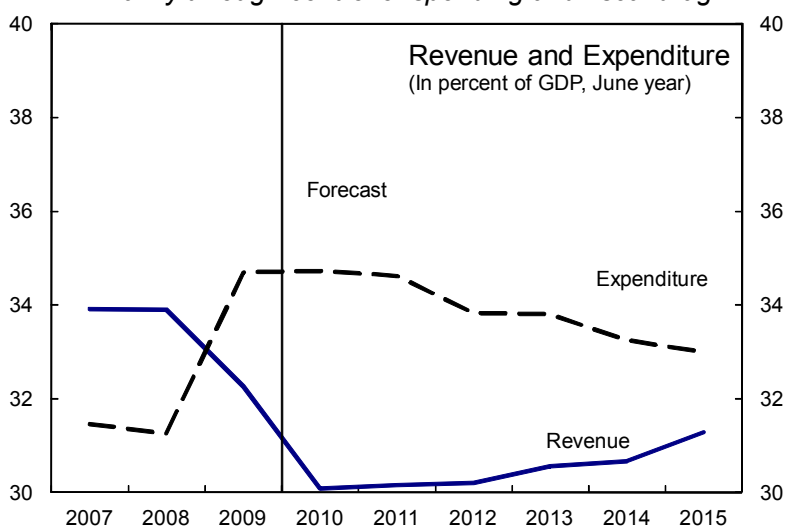

Net debt peaks in FY2016 and the budget balance moves back to balance in FY 2016.

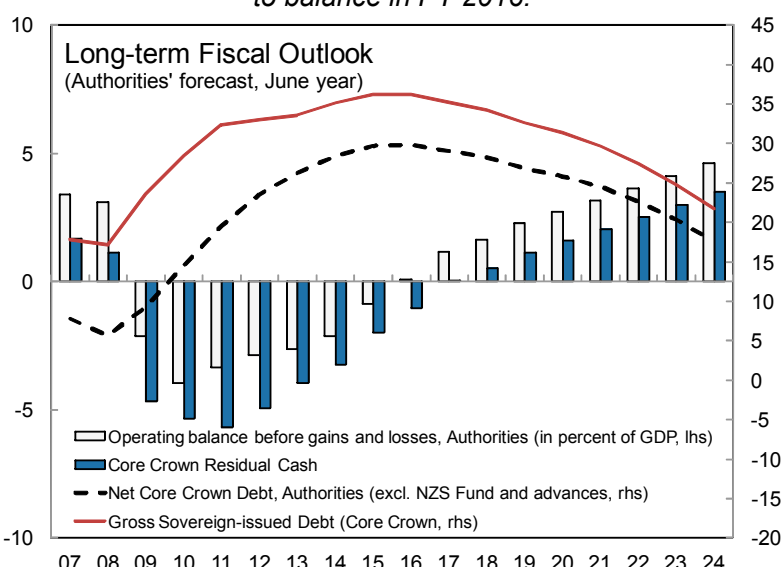

...as the authorities gradually reduce the deficit...
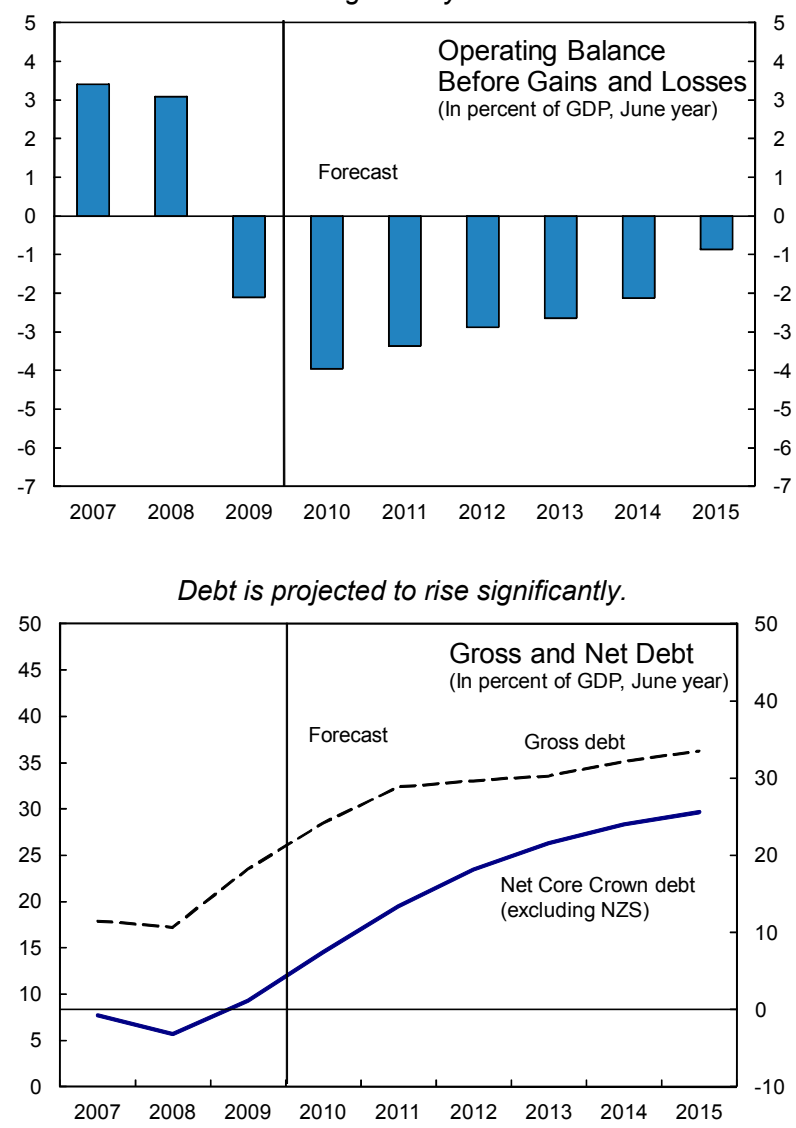

Staff's suggested front-loaded fiscal adjustment would see an earlier return to surpluses and a lower peak in net debt.

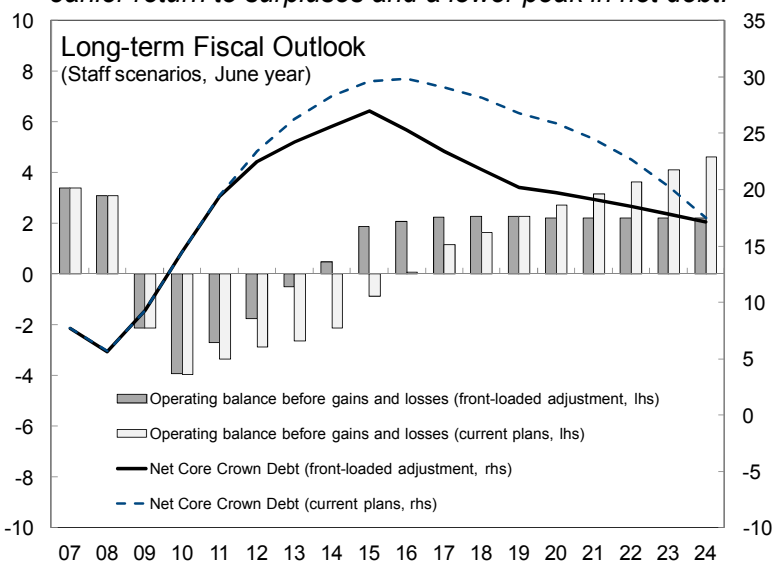

Note: Fiscal years ending June 30.

Sources: The New Zealand Treasury; Statistics New Zealand; and Fund staff calculations and projections. 
Figure 9. New Zealand: Comparison of Fiscal Outlook

The change in the budget balance was larger than for most advanced economies..

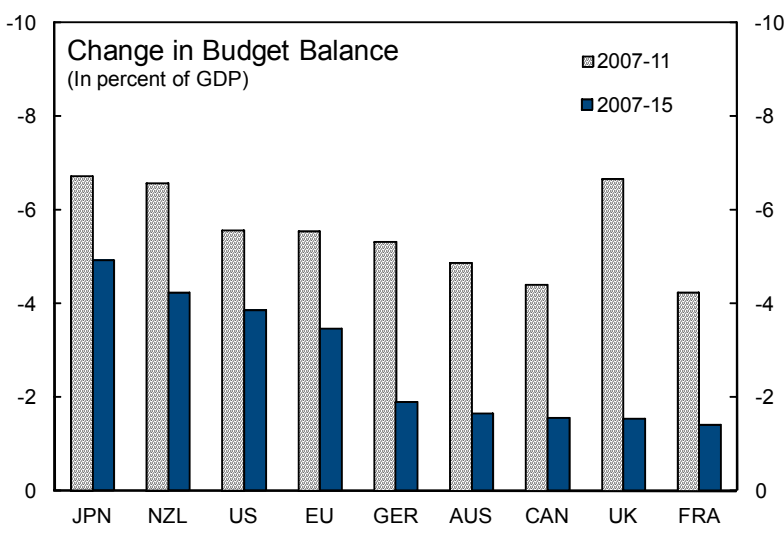

...as was the fiscal impulse.

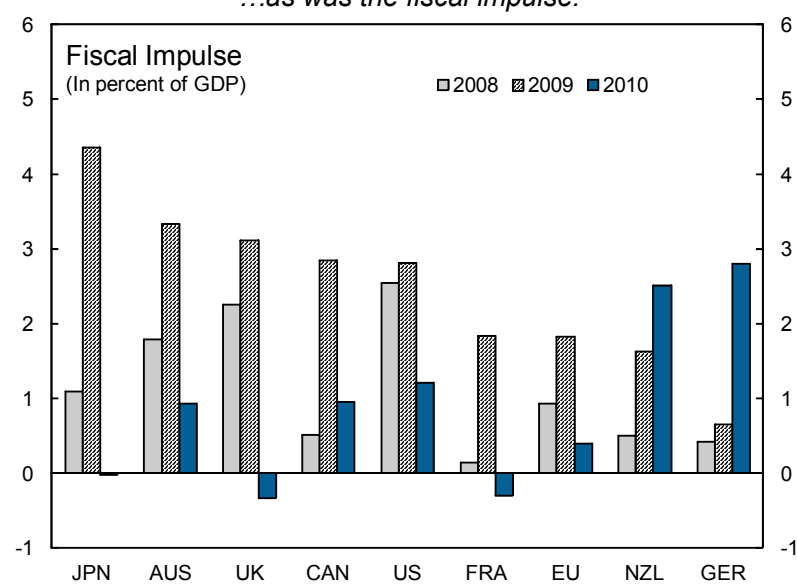

...the increase in gross debt is expected to be smaller than average....

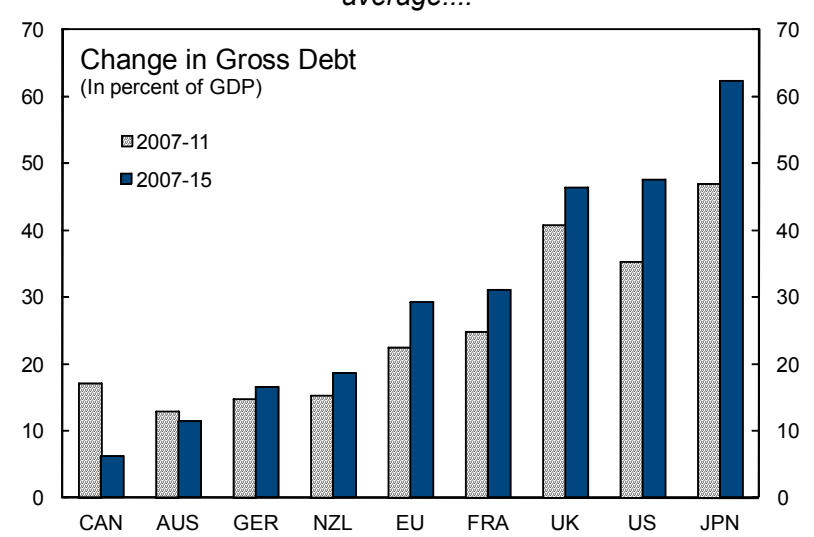

...as the fiscal stimulus was larger than average...

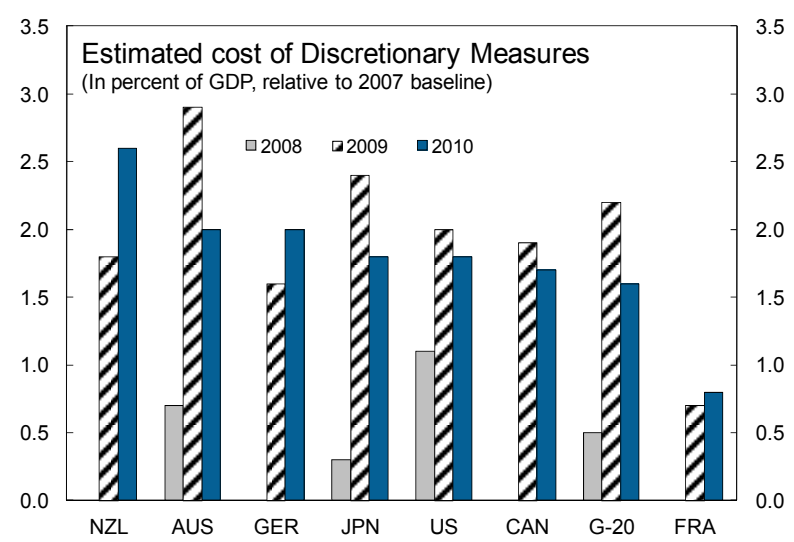

But as New Zealand started with a surplus...

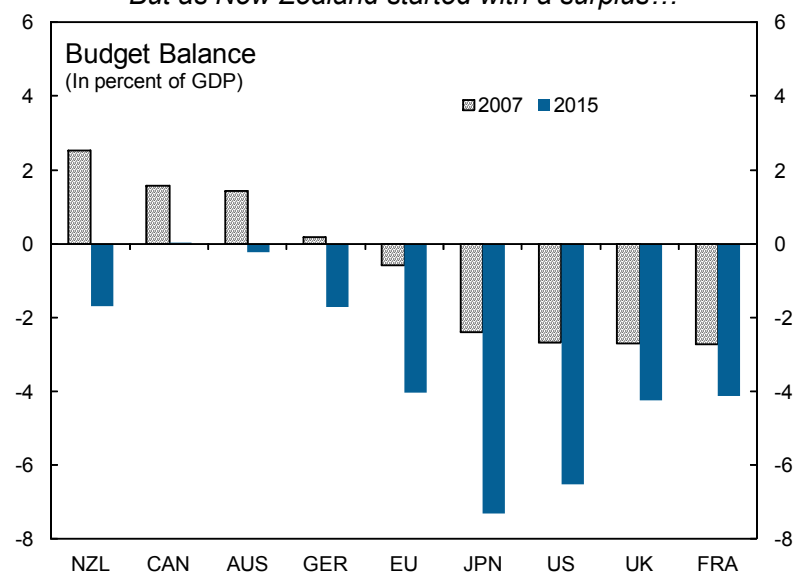

...and gross debt is projected to remain low by advanced economy standards.

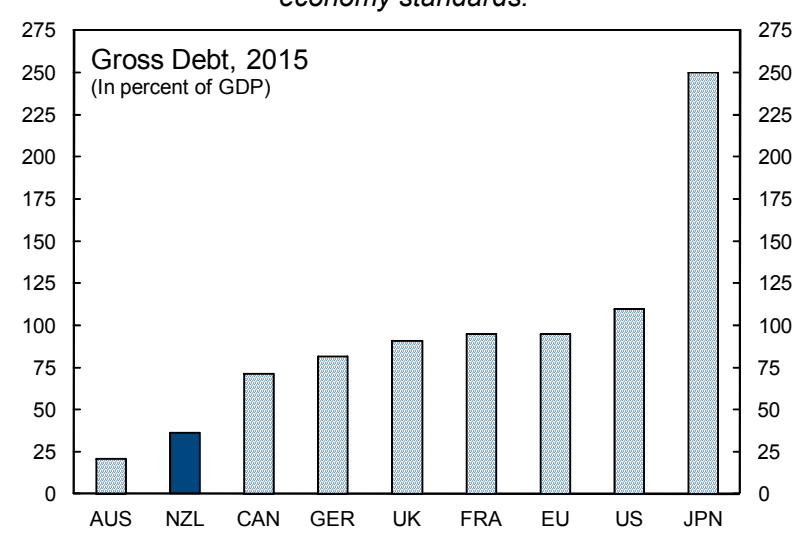

Note: Fiscal years ending June 30.

Sources: The New Zealand Treasury; SNZ; World Economic Outlook; and Fund staff calculations and projections. 
19. Nevertheless, staff advised further spending restraint to return to surpluses earlier than planned. Faster consolidation over the next 3-4 years would take pressure off monetary policy and the exchange rate, thereby helping rebalance the economy toward the tradables sector and contain the current account deficit. The mission recommended returning the budget to surplus by 2014, unless the downside risks to growth materialize, based on the following:

- Upfront adjustment would create fiscal space as insurance against future shocks that may arise in coming years. A key lesson from the global financial crises is the desirability of fiscal space to run larger deficits when needed without raising market concerns about fiscal sustainability.

- Although public debt is projected to remain low by advanced country standards, New Zealand's large gross external debt (130 percent of GDP) calls for greater fiscal prudence. If global interest rates rise because of large sovereign and bank borrowing in advanced countries, low public debt would help contain the rise in New Zealand's cost of capital (see forthcoming working paper).

- $\quad$ Staff analysis with the Global Integrated Monetary and Fiscal (GIMF) model shows that faster fiscal consolidation would lead to a depreciation of the exchange rate, a smaller sovereign risk premium, and a lower current account deficit (see selected issues paper).

- While the probability is extremely low, the government may need to take on more external debt should the banks once again have difficulties in global markets. This limits the extent to which public debt can be increased without hurting investor confidence.

- Finally, reaching a lower level of debt earlier than planned would put the budget in a stronger position to deal with the fiscal costs of ageing.

20. Staff recommended that concrete measures to control spending be introduced and that any positive revenue surprises be saved. Expenditure is projected to remain high at 33 percent of GDP by 2015 compared with 31 percent of GDP in 2008, mainly because of higher social spending. The staff noted scope to better target transfers to households, improve the efficiency of public service provision, and rationalize capital spending, which is high by advanced economy standards. The introduction of spending caps may also provide useful discipline.

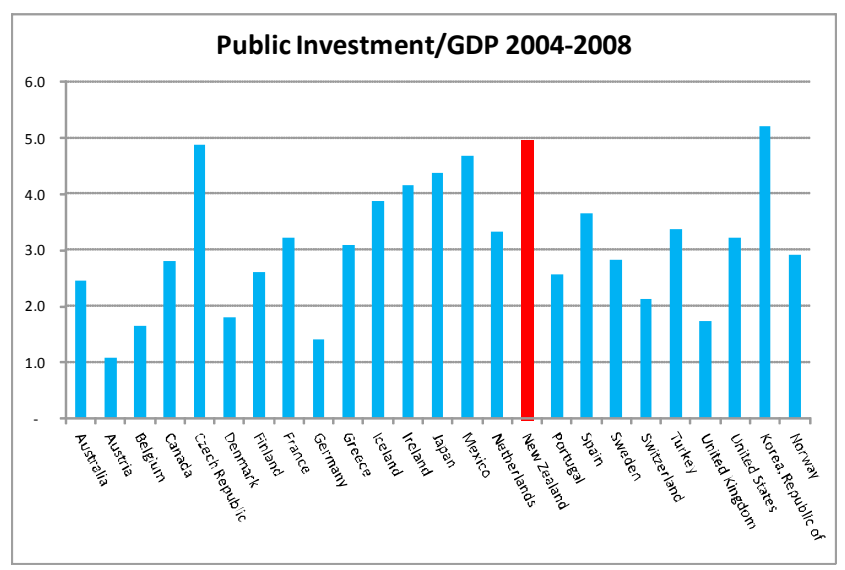




\begin{tabular}{|lcrr|}
\hline \multicolumn{4}{|c|}{$\begin{array}{c}\text { Government Transfers to Households } \\
\text { (In percent of GDP) }\end{array}$} \\
\hline \multicolumn{4}{|c}{} \\
\hline NZ Superannuation & 2005 & 2009 & 2014 \\
Unemployment benefit & 4.0 & 4.3 & 4.7 \\
Family and in-work tax credit & 0.5 & 0.3 & 0.4 \\
Other benefits & 0.6 & 1.5 & 1.3 \\
Total benefit expenses & 3.4 & 3.3 & 3.4 \\
Student loans & 8.8 & 9.6 & 10.0 \\
Kiwi Saver subsidy & 0.3 & 0.7 & 0.4 \\
Total transfers to households & 0.0 & 0.7 & 0.5 \\
\hline Source: New Zealand Treasury, HYEFU December 2009. & 10.9 \\
\hline
\end{tabular}

21. Tax reforms could help raise potential growth. Shifting the tax burden from income to consumption - as suggested by the Tax Working Group established by government-would raise incentives to work and invest. In addition, reducing tax incentives to invest in rental properties may help improve the allocation of capital. Staff analysis, suggests that a 1 percent of GDP shift of taxes from capital and labor to the goods and services tax could raise the level of real GDP by almost 1 percent after 5-6 years.

22. To address longer-term pressures on the budget, the mission advised early steps to contain growth in health care and pensions costs. Measures could include improving the efficiency of health care spending, raising the pension eligibility age, and linking it to life expectancy.

\section{B. Exit from Monetary Stimulus}

23. The RBNZ announced last year that it would keep the policy rate on hold until mid-2010 and thereafter gradually return to a neutral rate. Markets have priced in rate hikes of 150 basis points over the coming year. The authorities have started to unwind crisis-related measures by scaling back extraordinary liquidity support (Figure 10, Table 5).

\section{Staff supported the current accommodative monetary policy stance and the} RBNZ's intention to gradually return to neutral rates once the recovery is well established. Over the next few years, inflation is likely to stay within the RBNZ's 13 percent target, albeit toward the upper end of that range. Staff estimates that the output gap will not close before 2013. Inflation is also being limited by a tightening in monetary conditions over the past year with the appreciation of the currency, higher medium-term interest rates, and an increase in funding costs of banks, as they compete for retail deposits.

25. The rising wedge between the policy rate and bank funding costs suggests that the neutral policy rate is likely to be lower than in the past. Moreover, when the RBNZ begins to tighten, the transmission of the policy rate to mortgage rates should be relatively fast, as many households have refinanced mortgages at variable rates. 
Figure 10. Financial Sector: Exit from Monetary Stimulus

Financial conditions have tightened slightly in recent quarters...

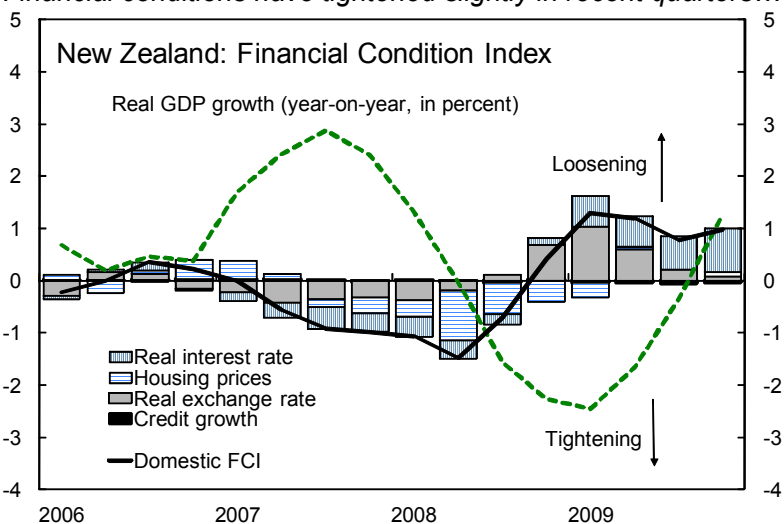

...and improved market conditions allowed banks to issue nonguaranteed bonds.

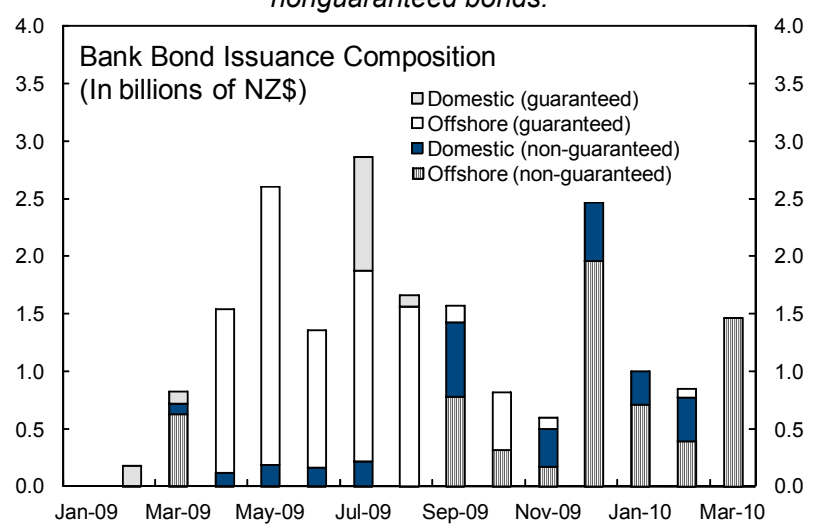

Financial markets are pricing in an increase in the official cash rate,...

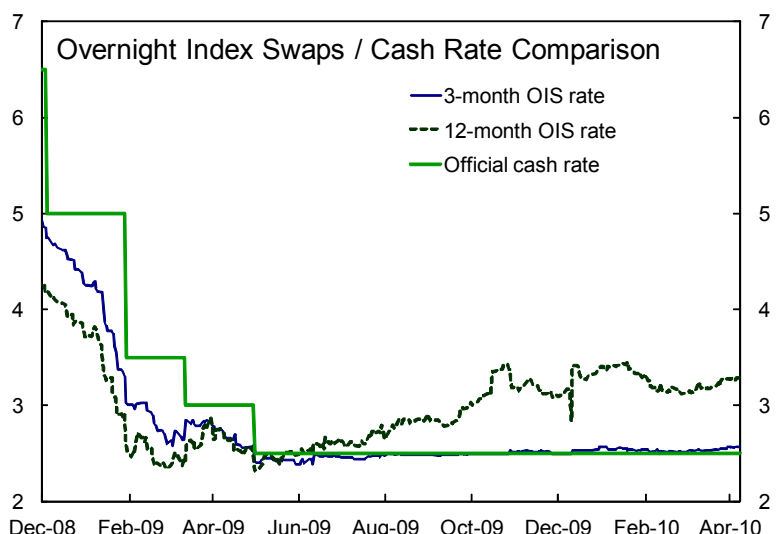

...and the Reserve Bank began to exit from liquidity support...

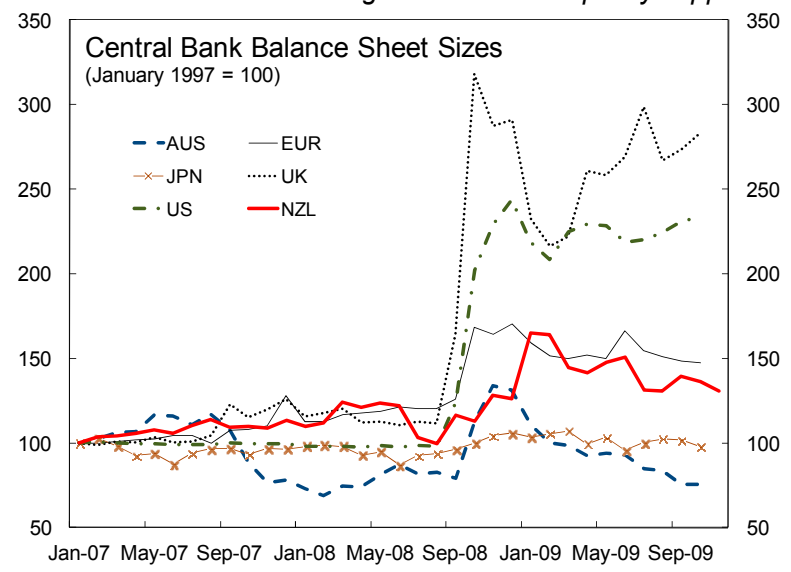

Appropriate pricing contained the size of debt guarantees.

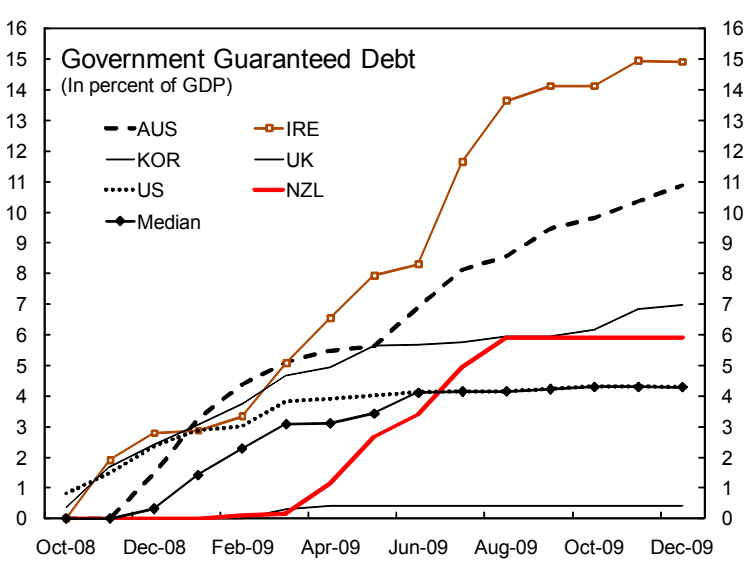

...which is also reflected in the yield curve.

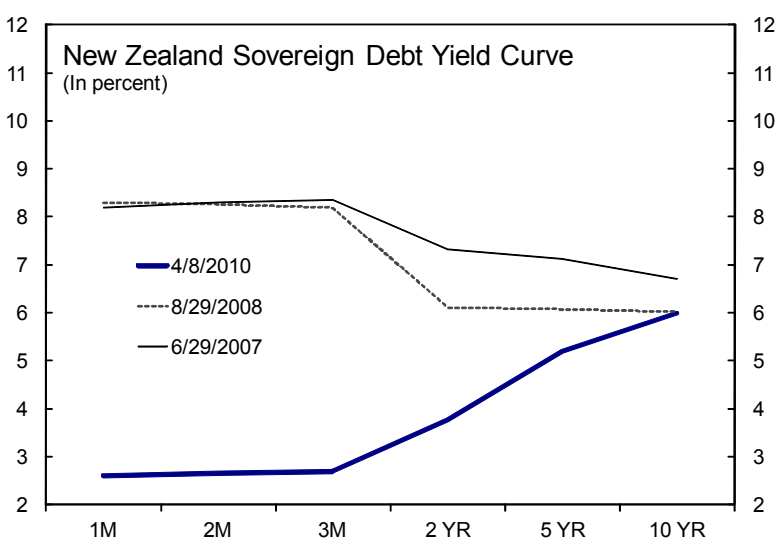

Sources: Reserve Bank of New Zealand; Haver Analytics database; Bloomberg; World Economic Outlook. 
26. In a downside scenario, monetary policy still has room to be loosened. Weakerthan-expected global growth and higher risk premia on New Zealand assets would spill over to the domestic economy through weaker commodity prices, growth, and inflation. In this scenario, the policy interest rate could be cut and any consequent weakening of the currency would ease financial conditions and cushion the impact on New Zealand.

\section{The inflation-targeting framework served New Zealand well during the global} financial crisis. The official cash rate (OCR) was high before the crisis, at $81 / 4$ percent, because of monetary tightening in response to inflationary pressures in 2007/08 stemming from the housing boom. While the RBNZ does not directly target house prices, it takes account of the impact of changes in house prices on consumer spending. The framework was flexible enough to allow a substantial cut in the OCR to $2 \frac{1}{2}$ percent by early 2009 . Importantly, the inflation target effectively anchored medium-term inflation expectations and was helpful in reducing the likelihood of deflation in the midst of the recession.

\section{Staff noted that the inflation target of " $1-3$ percent on average over the medium} term" is appropriate and consistent with international best practice. The government is not planning a revision to the target but there has been some debate in New Zealand recently on whether to raise the inflation target. In the staff's view, increasing the inflation target would provide no clear benefits and may entail a number of costs, including greater inflation uncertainty and reduced credibility of the authorities' commitment to price stability. In turn, this could lead to a higher cost of capital and lower potential growth given New Zealand's reliance on international capital markets to fund current account deficits and rollover sizable external debt.

\section{Maintaining Financial Sector Stability}

\section{The key domestic vulnerability is banks' exposure to household debt of just} over 150 percent of disposable income (Figure 11). However, this exposure proved to be relatively low risk in the recent recession. Factors mitigating the mortgage risks include the fall in mortgage rates, the absence of a sharp rise in unemployment, and only a 4 percent fall in house prices from the peak in 2007. Moreover, household debt has fallen from a peak of about 160 percent of disposable income in 2008. Nonetheless, risks remain. House prices are high relative to historical price-to-income ratios and debt-service burdens will rise with a return to neutral policy rates. In a downside scenario, a sharp decline in house prices and a jump in unemployment could lead to further deleveraging by households and an increase in banks' impaired assets. However, the risk to banks is mitigated by their limited exposure to high risk mortgages. ${ }^{2}$ Other vulnerabilities include banks' substantial exposure to dairy farming (where world market prices are volatile), commercial property, and small and medium-sized enterprises.

\footnotetext{
${ }^{2}$ Less than 5 percent of owner-occupied mortgages had loan-to-value rates greater than 80 percent and debt service ratios greater than 30 percent. Moreover, previous staff analysis (WP/09/224) suggests that bank capital would be resilient to a sharp increase in mortgage defaults.
} 
Figure 11. New Zealand: Household Vulnerabilities

Household debt is relatively high.

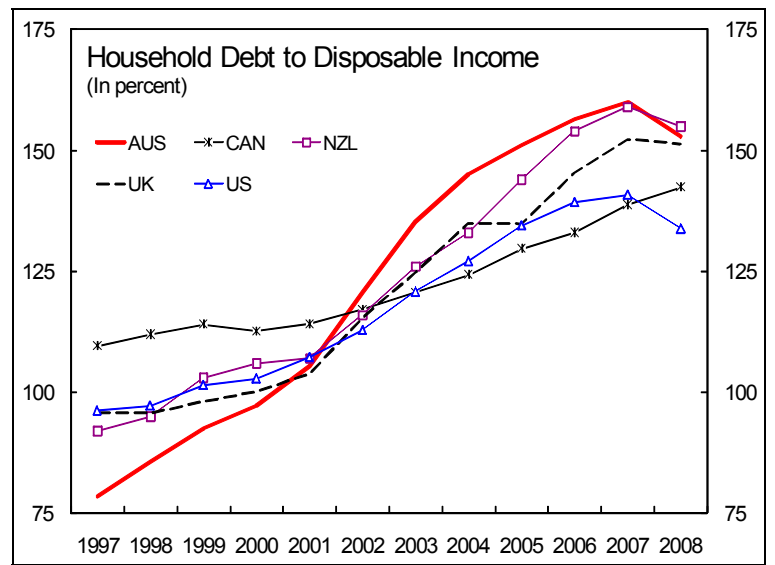

Banks are exposed to households.

Bank Assets Composition, 2009

(In billions of NZ\$)

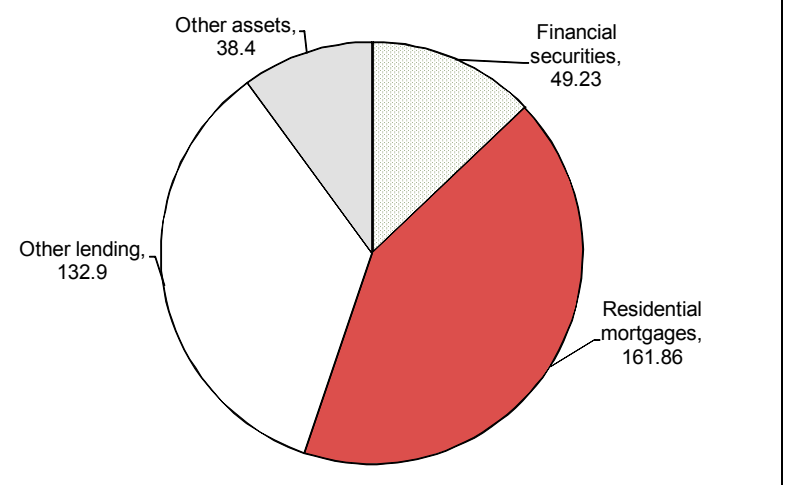

House prices remain high relative to income....

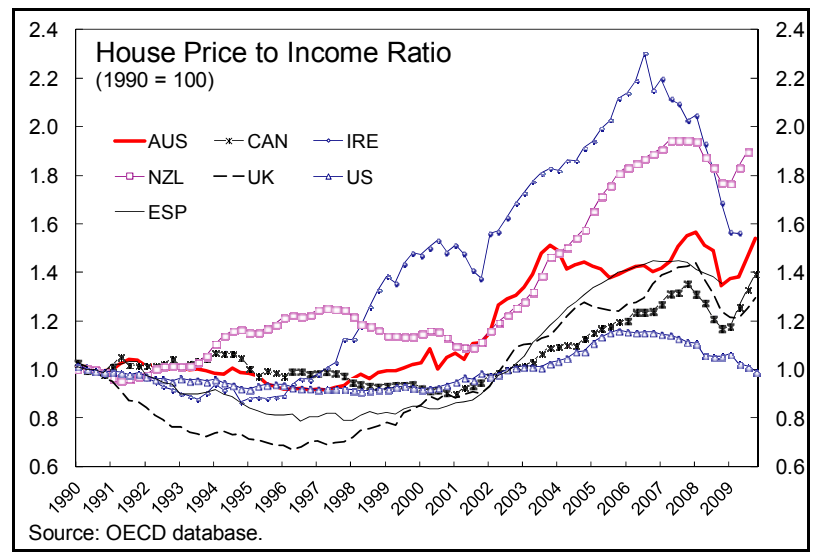

The debt servicing burden rose sharply since 2002, but eased in 2009 .

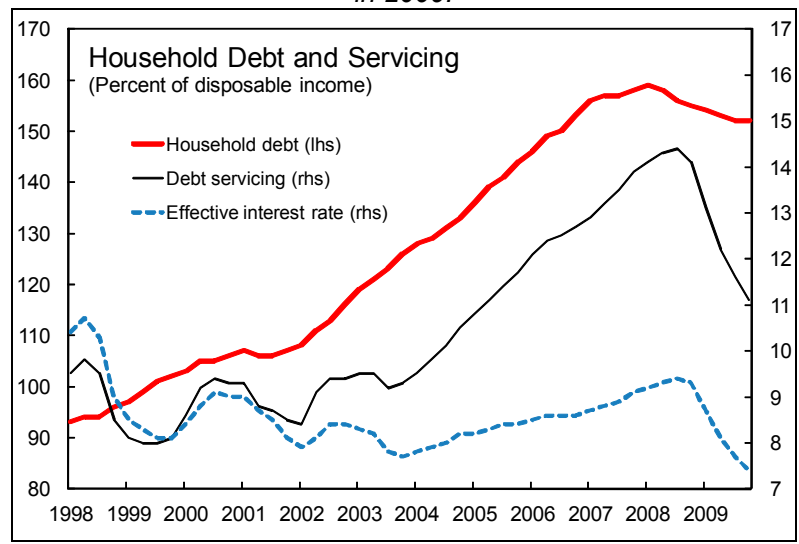

House prices fell from the peak in 2007 but are recovering.

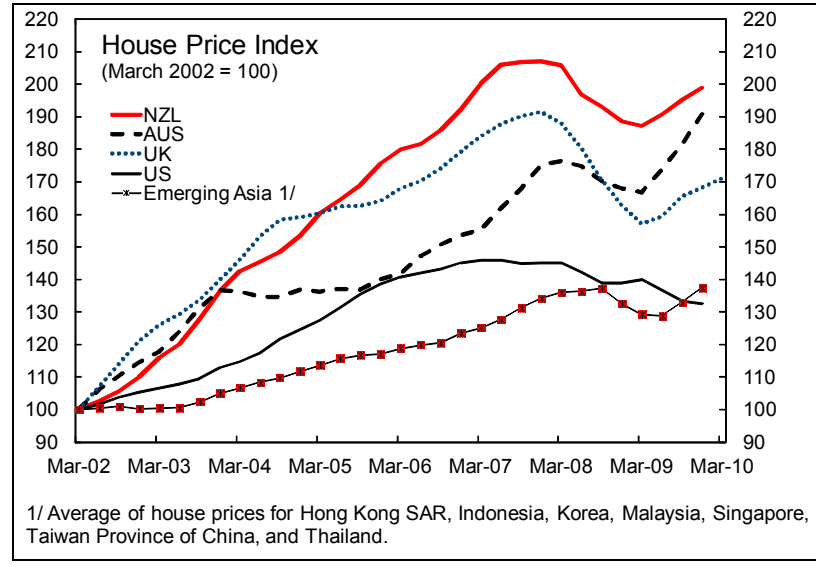

....and the house price-to-rent ratio is also high by advanced economy standards.

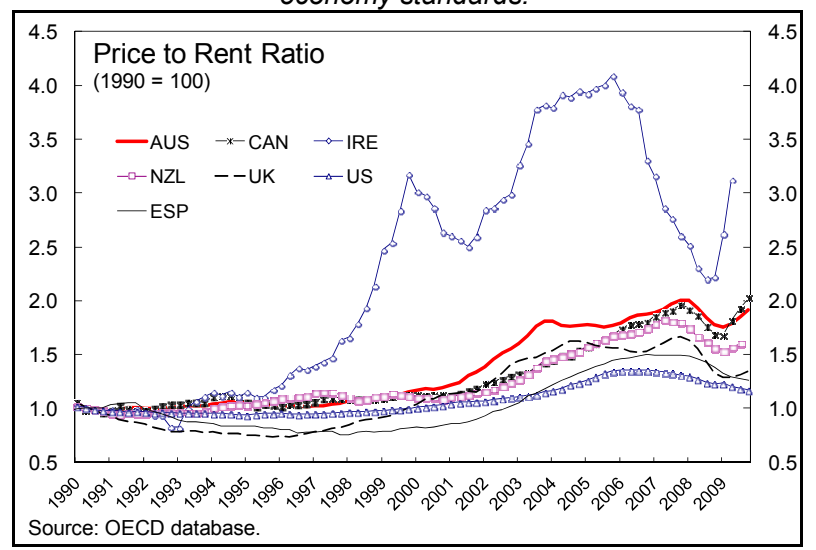

Sources: Reserve Bank of New Zealand; SNZ; Haver; Analytics Database; International Financial Statistics Database. 
30. A conservative approach to bank regulation and supervision helped banks weather the crisis. As a result, banks had relatively low leverage and high capital adequacy, with Tier 1 ratios of 7-8 percent before the crisis hit. In implementing the Basel II framework, the authorities required banks to hold relatively high capital. For example, a 20 percent loss-given-default floor was adopted for residential mortgages, higher than the Basel II 10 percent floor (text table). Staff welcomed the Reserve Bank's current review of capital adequacy associated with agricultural loans.

Risk Weights for Banks' Internal Models Under the Basel II Capital Framework

\begin{tabular}{|c|c|c|c|}
\hline & \multicolumn{2}{|c|}{ New Zealand } & \multirow[t]{2}{*}{ Australia } \\
\hline & $\begin{array}{l}\text { Initial bank } \\
\text { position }\end{array}$ & $\begin{array}{l}\text { Final position } \\
\text { after RBNZ actions }\end{array}$ & \\
\hline \multicolumn{4}{|l|}{ Housing loans: } \\
\hline Loss given default 1/ & $\begin{array}{l}10 \% \text { and not sensitive to } \\
\text { loan-to-value (LVR) }\end{array}$ & $\begin{array}{l}\text { Just over } 20 \% \text { and } \\
\text { sensitive to LVR }\end{array}$ & $20 \%$ minimum \\
\hline \multicolumn{4}{|l|}{ Long run portfolio } \\
\hline probability of default & about $0.5 \%$ & $1.25 \%$ minimum & $0.8 \%$ \\
\hline Average risk weight & $10 \%$ & $30 \%$ & $15-20 \%$ \\
\hline \multicolumn{4}{|l|}{ Rural loans: } \\
\hline Average risk weight & $50 \%$ & $\begin{array}{l}\text { System average of } \\
80-90 \%\end{array}$ & $\cdots$ \\
\hline \multicolumn{4}{|l|}{ Credit cards: } \\
\hline Average risk weight & about $30 \%$ & $80 \%$ & $30-50 \%$ \\
\hline
\end{tabular}

\section{Staff supported closer collaboration with Australian authorities on regular} stress tests and crisis management. The tests use more extreme scenarios than in past exercises and staff advised that capital and provisioning be strengthened if these tests suggest the need for additional buffers. Staff welcomed the crisis management toolkit, developed with the Australian authorities, and the intention to undertake a Trans-Tasman crisis management exercise in 2011.

32. The authorities intend to investigate the costs and benefits of potential macroprudential policy tools, particularly some of the proposals coming out of the Basel Committee on Banking Supervision. The authorities are researching the merits of time varying capital overlays under Pillar 2 and time varying liquidity requirements. Staff noted that macro-prudential measures may be useful to manage risks arising from excessive bank credit growth during upswings.

33. Staff welcomed the announced closure of the wholesale government guarantee scheme by end-April 2010, given that funding conditions have improved. The authorities are considering the costs and benefits of introducing a permanent retail deposit insurance scheme when the current government guarantee expires at end 2011. The RBNZ is also strengthening the nonbank prudential regulatory regime, including mandatory credit ratings from March 2010 and capital requirements.

\section{Addressing External Vulnerability and Increasing Saving}

34. The free-floating exchange rate regime remains appropriate, as it enables an independent monetary policy and provides a useful buffer against shocks. Prior to the crisis, the RBNZ was able to increase the policy rate to contain inflationary pressures fuelled 
by the housing boom. Moreover, the flexible exchange rate has moved with world commodity prices and thereby reduced the volatility of farm incomes in New Zealand.

\section{While there is uncertainty, staff estimates suggest the currency is overvalued by}

10-25 percent (Box 1). The overvaluation appears to be driven by a widening in interest differentials in the past year, given market expectations of an earlier tightening in monetary policy in New Zealand than in the United States (text figure). Therefore, part of the overvaluation may be temporary and the exchange rate may depreciate as the interest rate differential narrows with eventual tightening by the U.S. Federal Reserve.

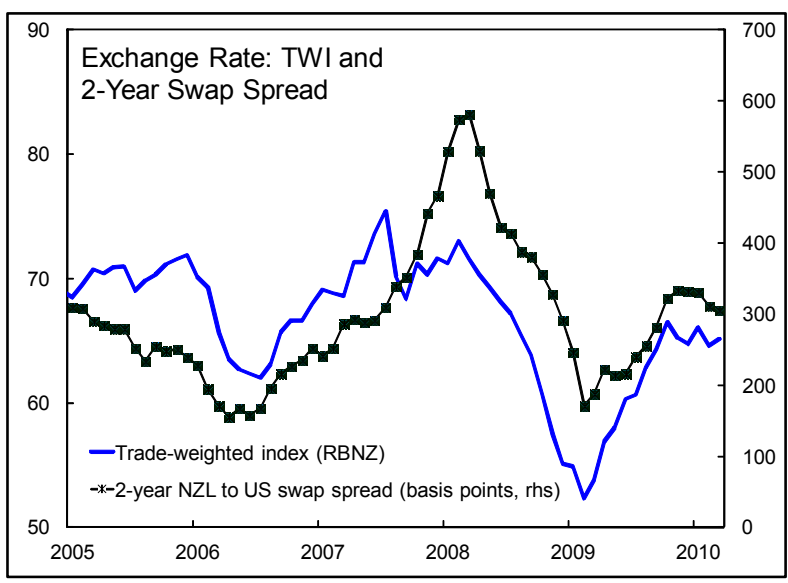

36. Assuming the exchange rate remains at present levels, staff projects the current account deficit to widen to over 8 percent of GDP by 2015. The deficit may not widen as much if the present overvaluation of the real effective exchange rate proves to be temporary. But even at staff's estimated savinginvestment norm (corresponding to a current account deficit of almost 5 percent of GDP), New Zealand's net foreign liabilities would remain high at 90 percent of GDP. A current account deficit of about 3 percent of GDP would be needed over the next 15 years to return net foreign liabilities to 75 percent of GDP, around the 2001-03 level, before the recent rise in external and household debt.

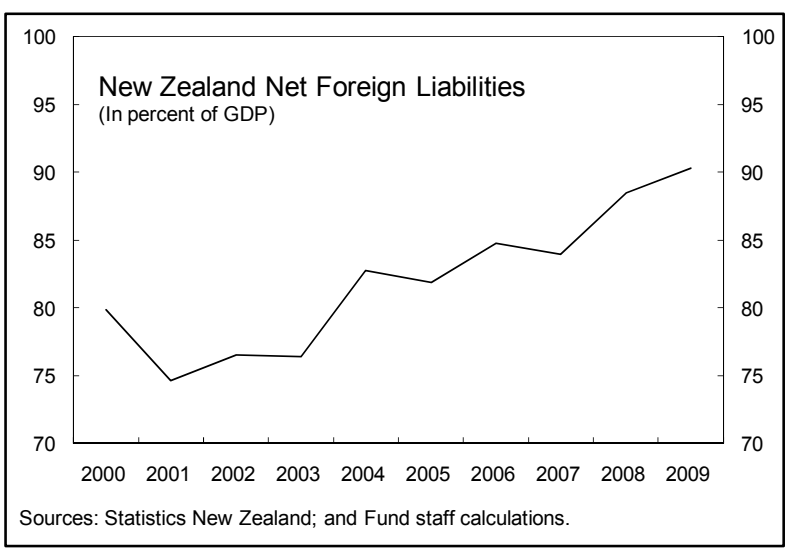

\section{Low household saving is a fundamental factor behind large current account} deficits and rising external debt in recent years (Box 2). Household saving fell to negative 10 percent of disposable income in 2008, although the actual rate may be higher than that given statistical problems. The current government is considering shifting the tax burden away from income to consumption to encourage saving. Staff simulations with the Fund's GIMF model illustrate that a 1 percent of GDP revenue-neutral shift to consumption taxation would permanently raise national saving to GDP ratio by about 0.3 percentage points. 


\section{Box 1. NeW Zealand: EQuilibrium Real EFFeCtive ExChANGe RATE}

Staff estimates suggest that the New Zealand dollar is overvalued by $10-25$ percent. These estimates are based on the macroeconomic balance (MB), the equilibrium real exchange rate (ERER), and the external sustainability approach (ES).

\section{The MB estimates the current} account deficit norm at 4.7 percent of GDP. To close the gap between this norm and staff's projected medium-term current account deficit of 8.2 percent of GDP, the real effective exchange rate (REER) would need to depreciate by 17 percent.

\begin{tabular}{|c|c|c|c|}
\hline \multicolumn{4}{|c|}{ Exchange Rate Asses sment: Baseline Results ${ }^{1}$} \\
\hline & \multicolumn{2}{|c|}{ CAVGDP } & \multirow{2}{*}{$\frac{\text { REER }}{\text { Overvaluation }}$} \\
\hline & Norm & Projection $^{2}$ & \\
\hline \multicolumn{4}{|l|}{ MB Approach: ${ }^{3}$} \\
\hline Desk & -4.7 & -8.2 & 16.8 \\
\hline \multicolumn{4}{|l|}{ ERER Approach: ${ }^{4}$} \\
\hline Desk & $\ldots$ & $\ldots$ & 8.3 \\
\hline \multicolumn{4}{|l|}{ ES Approach: ${ }^{5}$} \\
\hline $\begin{array}{l}\text { NFL constant at } 90 \\
\text { percent of GDP }\end{array}$ & -4.1 & -8.2 & 19.6 \\
\hline \multicolumn{4}{|l|}{$\begin{array}{l}\text { to } 75 \text { percent of GDP by } \\
2025\end{array}$} \\
\hline \multicolumn{4}{|l|}{ Source: Fund staff estimates. } \\
\hline \multicolumn{4}{|c|}{$\begin{array}{l}\text { 1/ All results are expressed in percent. Detailed analys is is presented in the IMF } \\
\text { Working Paper (WP/09/07). }\end{array}$} \\
\hline $\begin{array}{l}\text { 2/ Staff projection of the underlyi } \\
\text { 3/ Bas ed on a semi-elasticity of } t \\
\text { 4/ Overvaluation is assessed rela } \\
\text { 5/ Based on nominal GDP growt }\end{array}$ & $\begin{array}{l}\text { GDP in } 2 C \\
\text { GDP with } \\
\text { the latest } \\
\text { f about } 5\end{array}$ & $\begin{array}{l}\text { to the REER of } \\
\text { f March } 2010 \text {. }\end{array}$ & \\
\hline
\end{tabular}

The ERER estimates suggest a smaller overvaluation. This approach explains the REER with terms-of-trade, relative productivity, and relative government consumption. It suggests an overvaluation of almost 10 percent, assuming some strengthening of the terms of trade over the medium-term.

The ES approach implies a larger overvaluation. To stabilize foreign liabilities (NFL) at their end2009 level of 90 percent of GDP, the REER would need to depreciate by 20 percent. However, to reduce NFL to a more sustainable level of 75 percent of GDP over fifteen years, the REER would need to depreciate by 25 percent.

The estimates are subject to considerable uncertainty, as shown by the wide range of the confidence intervals.
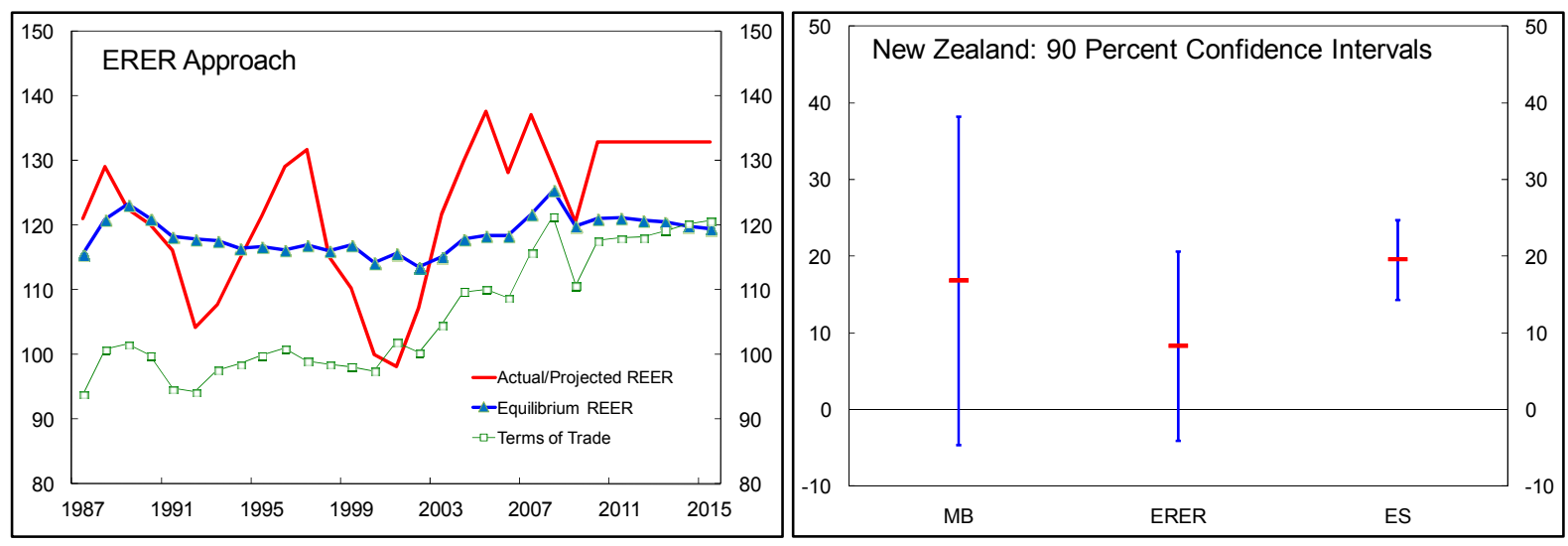
38. High short-term external debt remains a key vulnerability. Gross external debt exceeded 130 percent of GDP in 2009, about 44 percent of which is short-term, mostly held by banks (Figure 12). While shortterm external debt has fallen and market conditions have improved in the past year, rollover risks remain as short-term external debt is high by advanced economy standards.

\section{Staff welcomed the} introduction by the RBNZ of a prudential liquidity policy, including a core funding ratio that should reduce banks'

\begin{tabular}{|c|c|c|c|}
\hline New Zealand: Exte & ebt & & \\
\hline (End of Period) & Jun-08 & Dec-08 & Dec-09 \\
\hline $\begin{array}{l}\text { Gross external debt } \\
\text { (Expressed in NZ\$ billions) }\end{array}$ & 227 & 250 & 243 \\
\hline Of which: Short term & 117 & 119 & 108 \\
\hline $\begin{array}{l}\text { Gross external debt } \\
\text { (Expressed in US } \$ \text { billions) }\end{array}$ & 173 & 144 & 176 \\
\hline Of which: Short-term & 89 & 69 & 78 \\
\hline Gross external debt to GDP & $124 \%$ & $136 \%$ & $131 \%$ \\
\hline Of which: Short term to GDP & $64 \%$ & $65 \%$ & $58 \%$ \\
\hline Short-term to gross external debt & $51 \%$ & $48 \%$ & $44 \%$ \\
\hline $\begin{array}{l}\text { Memorandum item: } \\
\text { US\$/NZ\$ (end of period) }\end{array}$ & 0.76 & 0.58 & 0.72 \\
\hline
\end{tabular}
reliance on short-term external funding (Box 3). Planned increases in the core funding ratio over the next two years will further reduce this vulnerability and could, if needed, be increased more than planned to reduce short-term external debt.

\section{Vulnerabilities related to external debt would also be reduced by structural} reforms to raise productivity and labor force participation, thereby lifting export capacity. The government is considering a number of reforms with this aim, including tax and benefit reforms, streamlining regulation, and establishing a Productivity Commission.

\section{E. Authorities' Views on Staff Advice}

\section{The authorities were more upbeat than staff on the near-term economic}

outlook. They project real GDP growth to pick up slightly quicker in the near term and reach almost $3 \frac{1}{2}$ percent in March year 2012, about $1 / 4$ percent stronger than staff projections. While they acknowledged the risks raised by staff, they were more optimistic about the near-term upside risks, given the economy's growing links to Asia and Australia.

\footnotetext{
${ }^{3}$ Prepared in co-operation with the authorities.
} 


\section{BOX 2: NEW ZEALAND: SAVING AND INVESTMENT}

A fundamental factor behind high current account deficits in New Zealand is low national saving. Gross national saving was about 4 percent of GDP lower that the average for Australia, Canada and the U.S. for 2004-08, while gross investment was only $1 / 2$ percent of GDP higher. Private saving, especially household saving, appears low by advanced country standards. Experimental data published by Statistics New Zealand suggest that household saving fell from negative 5 percent of disposable income in $2000 / 01$ to negative 10 percent of disposable income in 2008 , although this is likely to be an underestimate due to deficiencies in sector statistics.

Previous staff analysis has shown that the long-term behavior of households' saving in New Zealand is explained by wealth, the pension and income support from government, the fiscal balance, and ease of access to credit (IMF Country Report No. 03/122 (Chapter 2)). With lower house prices, tighter credit conditions and fiscal deficits, household saving is expected to rise, relative to 2008 levels.

To raise household saving, the previous government introduced in 2007 an opt-out savings scheme (KiwiSaver). Incentives to participate include a \$NZ 1,000 kick start payment from the government and tax incentives. By September 2009, more than half of the labor force had joined the scheme. Despite KiwiSaver's success in terms of participation, it remains to be seen whether it will have a lasting impact on aggregate household saving.

While gross investment was comparable with other countries, public investment was high, and private non-residential investment was low. From 2004-08 public investment was $1 \frac{1}{2}$ percent of GDP higher than in Australia, Canada, and the U.S. However, there is uncertainty about whether public investment is materially higher in New Zealand, given the use of public-private partnerships in other countries.

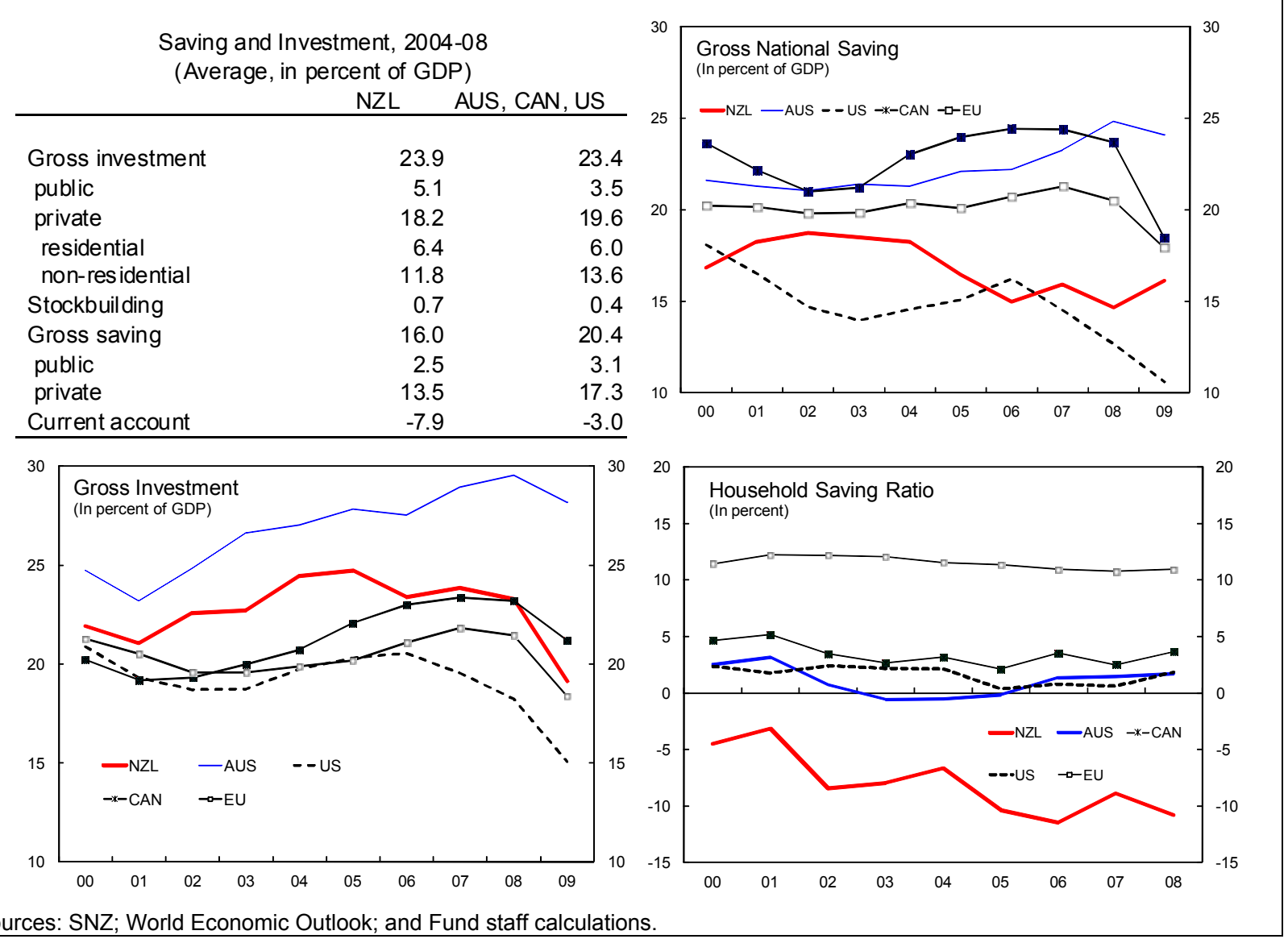


Figure 12. New Zealand: External Vulnerabilities

While net foreign liabilities are high, gross liabilities are lower than in many other advanced economies.

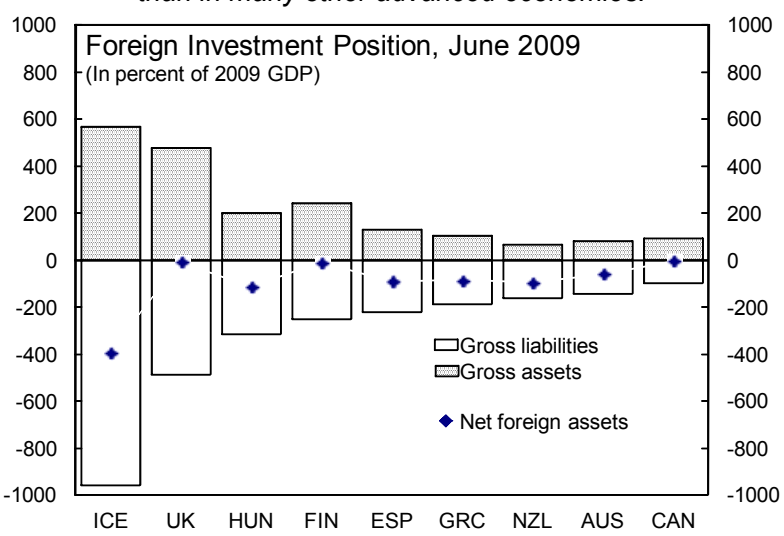

Short-term debt is high by advanced economy standards.

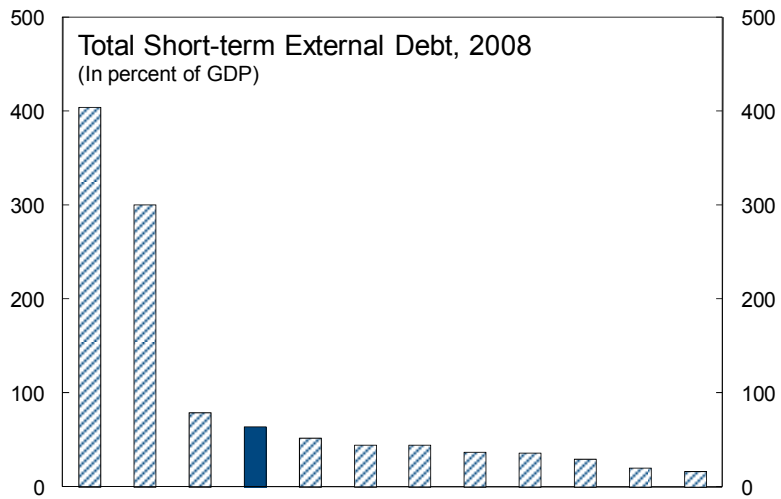

IRL UK PRT NZL AUS FIN ESP US GRC AUT CAN HUN

...to about 2 percent of GDP because of cyclical and other temporary factors.

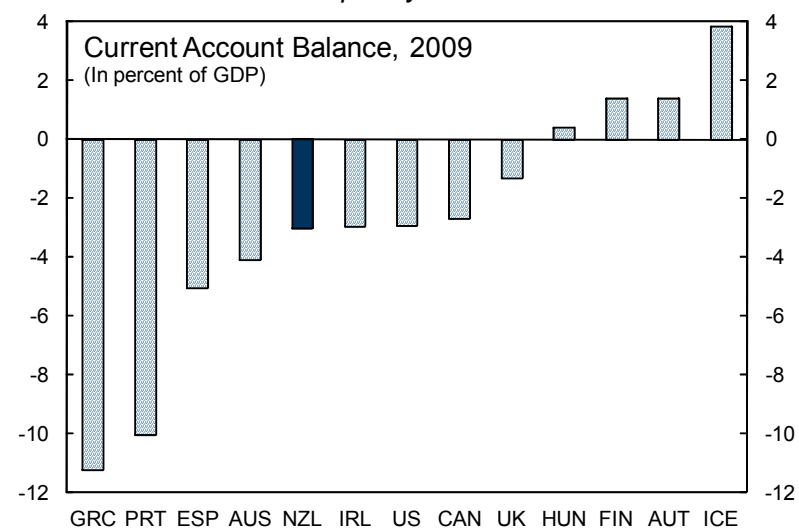

Most foreign debt is with banks and is short term.

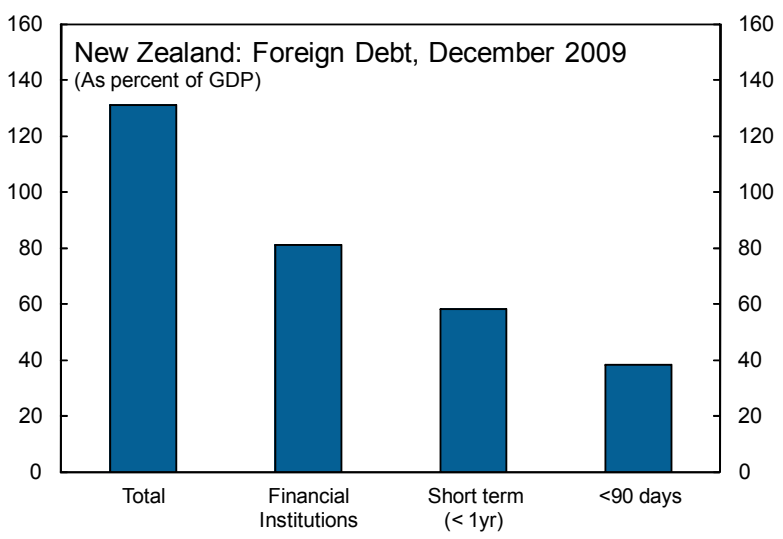

The current account deficit narrowed sharply in $2009 \ldots$

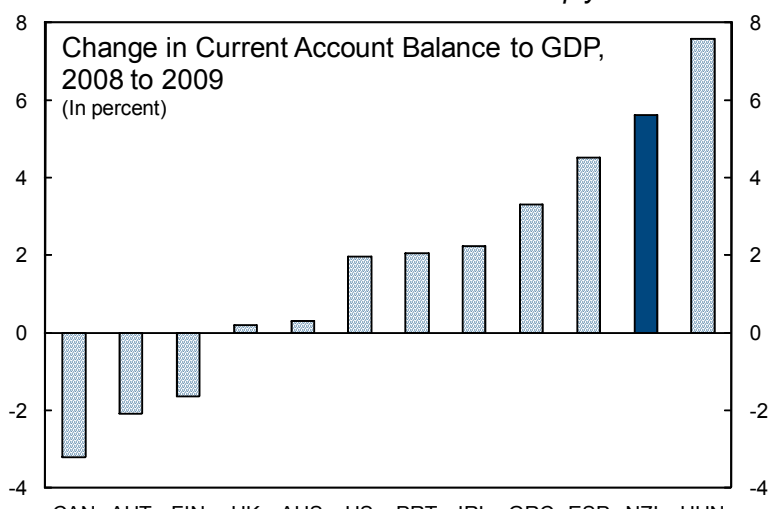

CAN AUT FIN UK AUS US PRT IRL GRC ESP NZL HUN

But staff project the deficit to widen over the medium term, worsening external vulnerability.

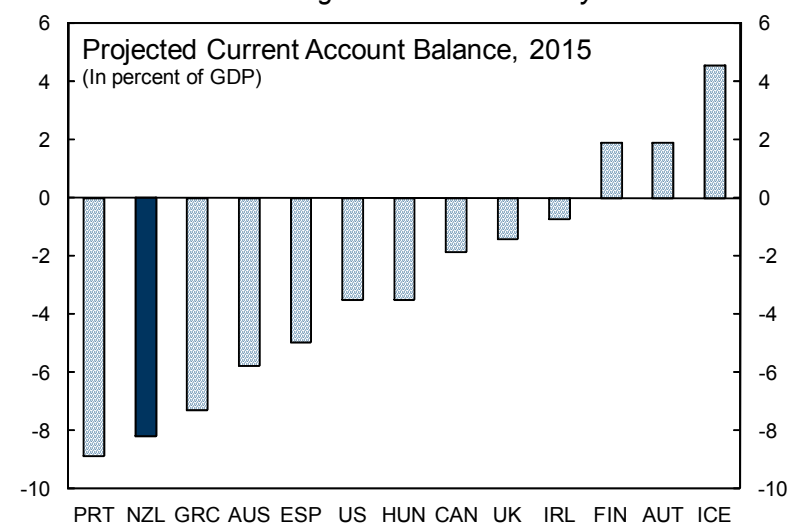

Sources: Reserve Bank of New Zealand; SNZ; Haver; Analytics database; World Economic Outlook database; International Financial Statistics database; and Fund staff estimates. 


\section{Box 3. New Zealand: NeW LiQuidity Policy}

The global financial crisis highlighted the need for banks to have adequate liquidity to safeguard financial stability. Given New Zealand banks' significant use of short-term offshore funding, the RBNZ moved ahead of other countries to implement a new liquidity policy for banks.

The new quantitative requirements (which are broadly consistent with the Basel Committee's proposals in December 2009) have two components - one aimed at short-term funding horizons, and one for the longer-term funding profile.

- Liquidity mismatch ratios set minimum 'zero' requirements for one-week and one-month each business day. The mismatch ratios compare a bank's likely cash inflows with its likely cash outflows.

\section{- A minimum core funding ratio (CFR)} aims to ensure that banks hold sufficient retail and longer-dated wholesale funding. The minimum CFR has been set at 65 percent from April 2010, increasing to 70 percent from July 2011 and to 75 percent from July 2012.

Since 2008, banks have almost doubled their holdings of liquid assets and increased retail and long-term wholesale funding. The new policy implies that banks may have to shift more than 10 percent of GDP of funding from short-term funding to longerterm maturities or to retail deposits, over the next two years. In turn, this should help reduce short-term external debt.

The new policy may also constrain the ability of banks to increase lending during cyclical upturns, when banks tend to resort to short-term offshore markets for additional funding.
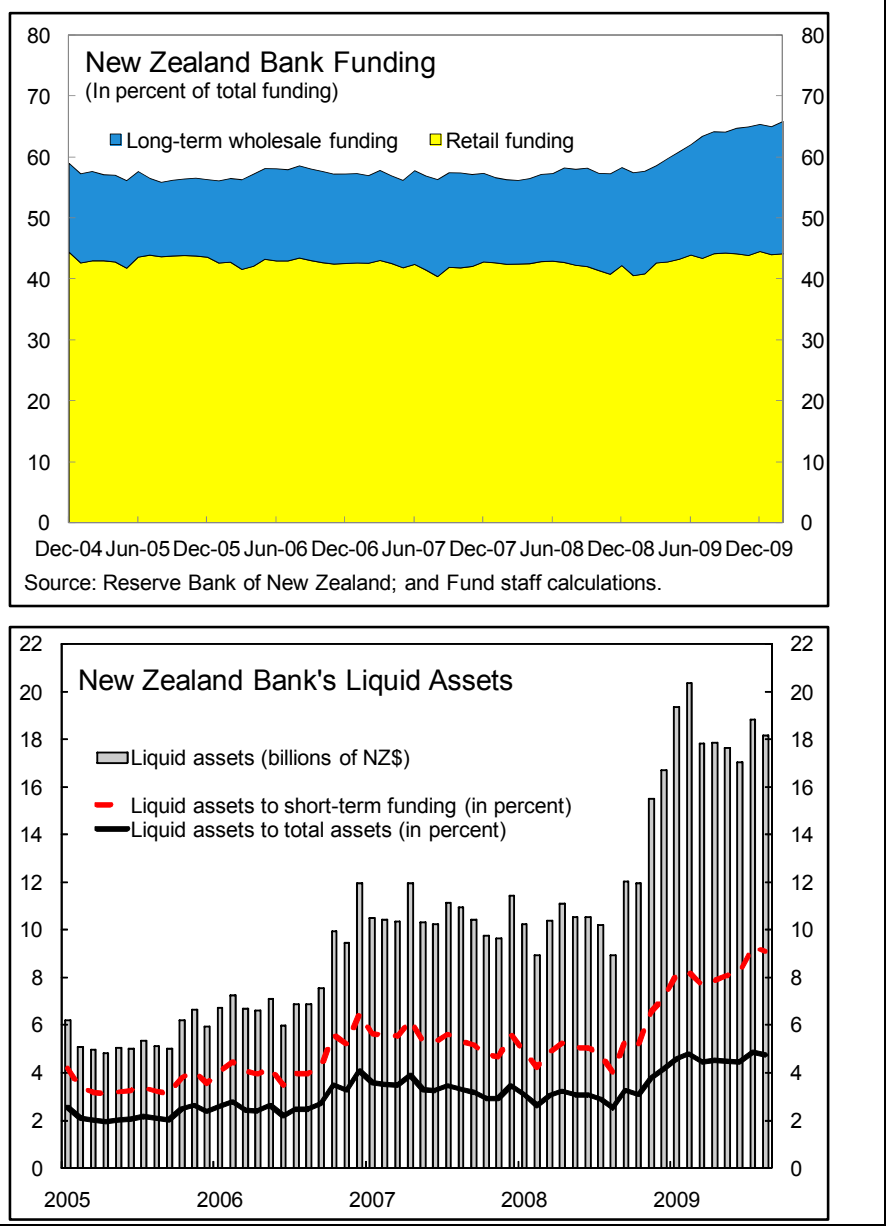
42. The authorities had considered the merits of faster fiscal consolidation, but decided that the current planned consolidation was appropriate. They share many of the considerations outlined by the staff, particularly the conclusion that a low level of net public debt is essential to keep the cost of capital low in the face of high external private debt. This assessment is reflected in their target for net public debt of 20 percent of GDP and the expectation to return the budget to balance in 2016, only two years after the staff's proposal. Current settings also allow for positive revenue surprises to be used to reduce the fiscal deficit. They consider that this path will restore New Zealand's ability to withstand potential future shocks and allows more time to develop sustained improvements in the quality of public spending. Their judgment is that while fiscal consolidation may help at the margin to rebalance the economy towards higher exports and savings, the impact on the current account deficit and growth is likely to be small and subject to a high degree of uncertainty.

43. The authorities agree that the exchange rate will need to be significantly lower for an extended period to get the net foreign liability position back to where it was five years ago. They expect a depreciation over the next few years as the world economy recovers and interest rate differentials normalize, but not to a level sufficient to prevent a projected widening of the current account deficit to 71/2 percent of GDP by 2014 and an increase in net foreign liabilities.

44. The authorities are following the international discussion of macro-prudential measures closely. However, they were cautious about the effectiveness of a number of the measures being discussed internationally and emphasized the scope for financial markets to work around some measures.

\section{Staff Appraisal}

45. A gradual economic recovery is expected to continue, helped by timely and significant macroeconomic stimulus. But the outlook is subject to a number of downside risks mainly related to the pace of the global recovery. Moreover, two key macro-financial vulnerabilities persist — high household debt and high external debt.

46. Reflecting a strong fiscal position prior to the crisis a sizable fiscal easing was already under way that helped cushion the impact of the crisis. However, the mediumterm fiscal outlook has worsened because income tax cuts and many of the spending initiatives were permanent and revenue projections have been revised down. As a result, cash budget deficits of about 3-6 percent of GDP are projected over the next 4-5 years.

47. The fiscal stimulus through June 2010 is appropriate, but meeting the government's commitment to limit the increase in public debt will be key to ensuring fiscal sustainability. The authorities' plans imply that net core Crown debt would peak at 30 percent of GDP in 2016 and fall below 20 percent of GDP by 2024. 
48. A shift in the macroeconomic policy mix toward faster fiscal consolidation would reduce the risk of a recurrence of external funding problems. Faster consolidation would relieve pressure on monetary policy and thereby the exchange rate, and limit the increase in the current account deficit. Faster consolidation would also create fiscal space to deal with future shocks, and reduce the likelihood of an increase in the risk premium related to New Zealand's high external debt.

49. Consolidation should focus on spending restraint to return to budget surpluses earlier than planned, unless the downside risks to growth materialize. There is scope to better target transfers to households and improve the efficiency of public service provision and capital spending. In addition, long-term pressures on the budget from rising health and pension costs should be addressed early. Any positive revenue surprises should be saved and the introduction of spending caps may provide useful discipline.

50. The current accommodative monetary stance is appropriate and the RBNZ should gradually return to neutral once the recovery is well established. Inflation is likely to stay within the 1-3 percent target over the next few years, as the output gap is not expected to close before 2013. In a downside scenario, monetary policy has room to be loosened. The inflation-targeting framework served New Zealand well during the global crisis and there are no clear net benefits to increasing the inflation target.

51. Banks remain sound, but the authorities should continue to be vigilant as banks are exposed to households and house prices appear overvalued. Closer collaboration with Australian authorities on crisis management and stress tests is welcome, and banks' capital and provisioning should be strengthened if these tests suggest the need for additional buffers.

\section{The exchange rate is overvalued by $\mathbf{1 0}-\mathbf{2 5}$ percent from a medium-term}

perspective. If this proves to be temporary, it may limit the increase in the current account deficit. But even if the current account returns to the estimated norm of almost 5 percent of GDP, net foreign liabilities would remain high at 90 percent of GDP.

53. Prudential and structural reforms would help reduce external vulnerability. The introduction of the prudential liquidity policy, including a core funding ratio, should reduce banks' reliance on short-term external funding. The core funding ratio could be raised further than planned if needed to help reduce short-term external debt. Further structural reforms to raise productivity and labor force participation, including tax and benefit reforms, would lift potential growth and export capacity.

54. Staff recommends that the next Article IV consultation be held on the standard 12month cycle. 
Table 1. New Zealand: Selected Economic and Financial Indicators, 2005-11

Nominal GDP (2009): $\quad$ US $\$ 117.7$ billion Population (2009):
4.3 million
GDP per capita (2009): $\quad$ US\$27,127

Quota: SDR 894.6 million

\begin{tabular}{|c|c|c|c|c|c|c|c|}
\hline & 2005 & 2006 & 2007 & 2008 & 2009 & $\begin{array}{c}2010 \\
\text { Proj. }\end{array}$ & $\begin{array}{l}2011 \\
\text { Proj. }\end{array}$ \\
\hline \multicolumn{8}{|l|}{ Real growth (percent change) } \\
\hline GDP (production basis) & 3.2 & 1.0 & 2.8 & -0.1 & -1.6 & 2.9 & 3.2 \\
\hline Final domestic demand & 4.7 & 1.9 & 4.3 & 0.0 & -3.4 & 3.0 & 3.7 \\
\hline Private consumption & 4.7 & 2.2 & 3.9 & -0.3 & -0.6 & 2.0 & 2.5 \\
\hline Government consumption & 3.9 & 5.3 & 4.1 & 4.8 & 1.5 & 1.9 & 2.0 \\
\hline Fixed investment & 5.2 & -1.0 & 5.5 & -2.6 & -13.5 & 6.9 & 8.2 \\
\hline Inventories $1 /$ & -0.1 & -0.8 & 0.4 & 0.4 & -2.5 & 2.0 & 0.0 \\
\hline Exports of goods and services & -0.4 & 1.7 & 3.8 & -1.4 & 0.0 & 2.1 & 5.9 \\
\hline Imports of goods and services & 5.5 & -2.5 & 8.7 & 2.5 & -15.2 & 8.7 & 7.0 \\
\hline Output gap & 2.7 & 1.0 & 1.3 & -0.7 & -3.7 & -2.9 & -1.8 \\
\hline Headline CPI inflation (percent change) & 3.0 & 3.4 & 2.4 & 4.0 & 2.1 & 2.1 & 2.5 \\
\hline End of period (percent change) & 3.2 & 2.7 & 3.2 & 3.4 & 2.0 & 2.3 & 2.8 \\
\hline Unemployment rate (period average, in percent) & 3.8 & 3.8 & 3.7 & 4.2 & 6.2 & 7.2 & 6.6 \\
\hline \multicolumn{8}{|l|}{ Investment and saving (in percent of GDP) } \\
\hline Investment & 24.7 & 23.4 & 23.9 & 23.3 & 19.2 & 20.9 & 22.0 \\
\hline National saving 2/ & 16.4 & 14.9 & 15.9 & 14.6 & 16.1 & 16.3 & 16.3 \\
\hline \multicolumn{8}{|l|}{ Public finance (in percent of GDP) $3 /$} \\
\hline Revenue & 38.0 & 37.0 & 33.9 & 33.9 & 32.2 & 30.1 & 30.2 \\
\hline Expenditure & 32.9 & 34.2 & 31.5 & 31.2 & 34.7 & 34.7 & 34.6 \\
\hline Operating balance $4 /$ & 5.4 & 4.2 & 3.8 & 2.1 & -3.2 & -3.7 & -3.9 \\
\hline Operating balance before gains and losses & 4.8 & 4.6 & 3.4 & 3.1 & -2.1 & -4.0 & -3.4 \\
\hline Net Crown debt excluding NZS Fund & 13.3 & 10.2 & 7.7 & 5.6 & 9.3 & 14.5 & 19.5 \\
\hline \multicolumn{8}{|l|}{ Money and credit (end of period) } \\
\hline Resident M3 (percent change) 5/ & 9.4 & 11.3 & 11.1 & 10.4 & -0.6 & -3.6 & $\ldots$ \\
\hline Private domestic credit (percent change) $5 /$ & 10.2 & 12.4 & 12.8 & 7.4 & 0.9 & 0.2 & $\ldots$ \\
\hline \multicolumn{8}{|l|}{ Interest rates (period average) } \\
\hline Interest rate (90-day, in percent) 6/ & 7.1 & 7.5 & 8.3 & 8.0 & 3.0 & 2.7 & $\ldots$ \\
\hline Government bond yield (10-year, in percent) $6 /$ & 5.9 & 5.8 & 6.3 & 6.1 & 5.5 & 5.9 & $\cdots$ \\
\hline \multicolumn{8}{|l|}{ Balance of payments (in percent of GDP) } \\
\hline Current account & -8.3 & -8.4 & -8.0 & -8.6 & -3.0 & -4.6 & -5.7 \\
\hline (In billions of New Zealand dollars) & -13.1 & -14.0 & -14.2 & -15.8 & -5.6 & -9.0 & -11.6 \\
\hline Trade balance (goods) & -2.3 & -1.8 & -1.3 & -1.2 & 1.3 & 1.6 & 1.6 \\
\hline Terms of trade (percent change) & 1.1 & 0.0 & 6.0 & 7.4 & -10.1 & 8.5 & 0.7 \\
\hline \multicolumn{8}{|l|}{ Foreign assets and liabilities (NZ\$ billion) } \\
\hline Net international investment position & -129.6 & -140.5 & -149.3 & -162.3 & -167.5 & -176.7 & -188.7 \\
\hline (In percent of GDP) & -81.9 & -84.8 & -83.9 & -88.5 & -90.3 & -90.8 & -92.4 \\
\hline Official reserves $5 /$ & 13.1 & 19.9 & 22.3 & 19.1 & 21.6 & 24.0 & $\ldots$ \\
\hline \multicolumn{8}{|l|}{ Exchange rate (period average) } \\
\hline U.S. dollar per New Zealand dollar 6/ & 0.70 & 0.65 & 0.74 & 0.71 & 0.63 & 0.71 & ... \\
\hline Trade-weighted index (June $1979=100) 6 /$ & 70.4 & 65.4 & 70.9 & 65.7 & 60.2 & 64.8 & $\ldots$ \\
\hline Nominal effective exchange rate $7 /$ & 134.3 & 123.8 & 133.0 & 124.1 & 113.6 & 123.1 & $\ldots$ \\
\hline Real effective exchange rate $7 /$ & 137.6 & 128.2 & 137.8 & 128.9 & 120.5 & 130.9 & $\cdots$ \\
\hline GDP (in billions of New Zealand dollars) & 158.3 & 165.8 & 177.9 & 183.4 & 185.5 & 194.7 & 204.2 \\
\hline
\end{tabular}

Sources: Data provided by the New Zealand authorities; and Fund staff estimates and projections.

$1 /$ Contribution in percent of GDP.

2/ Based on national accounts data.

3/ Fiscal years ending June 30.

4/ Equals revenue less expenditure plus net surplus of state-owned enterprises and Crown entities.

5/ Data for 2010 are for February.

6/ Data for 2010 are for January-March.

7/ IMF Information Notice System index $(2000=100)$. Data for 2010 are as of February.

\section{CInternational Monetary Fund. Not for Redistribution}


Table 2. New Zealand: Summary of Central Government Budget, 2006/07-2010/11 1/

\begin{tabular}{|c|c|c|c|c|c|}
\hline & $2006 / 07$ & $2007 / 08$ & 2008/09 & $\begin{array}{r}\text { 2009/10 } \\
\text { Proj. }\end{array}$ & $\begin{array}{r}2010 / 11 \\
\text { Proj. }\end{array}$ \\
\hline & \multicolumn{5}{|c|}{ (In billions of New Zealand dollars) } \\
\hline Revenue & 58.2 & 61.8 & 59.5 & 56.8 & 60.0 \\
\hline Tax revenue & 53.5 & 56.7 & 54.7 & 51.2 & 54.3 \\
\hline Expenditure & 54.0 & 57.0 & 64.0 & 65.5 & 68.9 \\
\hline Social security and welfare & 16.8 & 17.9 & 19.4 & 21.2 & 22.2 \\
\hline Health & 10.4 & 11.3 & 12.4 & 13.4 & 13.5 \\
\hline Education & 9.3 & 9.6 & 11.5 & 11.6 & 11.8 \\
\hline Defense & 1.5 & 1.6 & 1.8 & 1.8 & 1.9 \\
\hline Finance costs & 2.2 & 2.3 & 2.7 & 2.9 & 3.7 \\
\hline Other & 13.9 & 14.4 & 16.3 & 14.5 & 15.9 \\
\hline Revenue less expenditure (core Crown) & 4.2 & 4.8 & -4.5 & -8.8 & -8.9 \\
\hline Net surplus from SOEs and Crown entities & 0.4 & 0.9 & 1.5 & 1.3 & 1.8 \\
\hline Operating balance (Core Crown) 2/ & 6.5 & 3.9 & -5.9 & -6.9 & -7.7 \\
\hline Operating balance before gains and losses (total Crown) & 5.9 & 5.6 & -3.9 & -7.5 & -6.7 \\
\hline Residual cash balance $3 /$ & 2.9 & 2.1 & -8.6 & -10.1 & -11.3 \\
\hline Gross sovereign-issued debt 4 / & 30.6 & 31.4 & 43.4 & 53.7 & 64.4 \\
\hline Net core Crown debt 5/ & 13.2 & 10.3 & 17.1 & 27.4 & 38.8 \\
\hline Net core Crown debt with NZ Superannuation Fund & -7.5 & -13.0 & -4.8 & 1.5 & 11.4 \\
\hline \multirow[t]{2}{*}{ Net worth $6 /$} & 96.8 & 105.5 & 99.5 & 94.8 & 89.7 \\
\hline & \multicolumn{5}{|c|}{ (In percent of GDP) } \\
\hline Revenue & 33.9 & 33.9 & 32.2 & 30.1 & 30.2 \\
\hline Tax revenue & 31.2 & 31.1 & 29.6 & 27.2 & 27.3 \\
\hline Expenditure & 31.5 & 31.2 & 34.7 & 34.7 & 34.6 \\
\hline Social security and welfare & 9.8 & 9.8 & 10.5 & 11.2 & 11.2 \\
\hline Health & 6.0 & 6.2 & 6.7 & 7.1 & 6.8 \\
\hline Education & 5.4 & 5.2 & 6.2 & 6.2 & 5.9 \\
\hline Defense & 0.9 & 0.9 & 1.0 & 1.0 & 0.9 \\
\hline Finance costs & 1.3 & 1.2 & 1.5 & 1.5 & 1.9 \\
\hline Other & 8.1 & 7.9 & 8.9 & 7.7 & 8.0 \\
\hline Net surplus from SOEs and Crown entities & 0.2 & 0.5 & 0.8 & 0.7 & 0.9 \\
\hline Operating balance $2 /$ & 3.8 & 2.1 & -3.2 & -3.7 & -3.9 \\
\hline Operating balance before gains and losses & 3.4 & 3.1 & -2.1 & -4.0 & -3.4 \\
\hline Residual cash balance 3/ & 1.7 & 1.1 & -4.7 & -5.3 & -5.7 \\
\hline Gross sovereign-issued debt 4 / & 17.9 & 17.2 & 23.5 & 28.4 & 32.3 \\
\hline Net core Crown debt $5 /$ & 7.7 & 5.6 & 9.3 & 14.5 & 19.5 \\
\hline Net core Crown debt with NZ Superannuation Fund & -4.3 & -7.1 & -2.6 & 0.8 & 5.7 \\
\hline Net worth $6 /$ & 56.4 & 57.8 & 54.0 & 50.3 & 45.0 \\
\hline \multicolumn{6}{|l|}{ Memorandum items (in billions of NZ dollars) } \\
\hline Contributions to NZ Superannuation Fund & 2.0 & 2.1 & 2.2 & 0.3 & 0.0 \\
\hline NZ Superannuation Fund balance & 7.6 & 7.8 & 7.4 & 8.3 & 8.3 \\
\hline
\end{tabular}

Sources: New Zealand Treasury; Economic and Fiscal Forecasts, December 2009; and Fund staff estimates and projections.

1/ Fiscal years ending June 30.

2/ Equals revenue less expenditure plus net surplus of state-owned enterprises and Crown entities.

3/ Net core Crown cashflow from operations after contributions to NZS Fund, purchases of physcial assets, and advances and capital injections.

4/ Excluding Reserve Bank settlement cash.

5/ Excluding NZ Superannuation Fund and advances.

$6 /$ Includes financial assets of the NZS Fund. 
Table 3. New Zealand: Balance of Payments and External Debt, 2004-10

\begin{tabular}{|c|c|c|c|c|c|c|c|}
\hline & 2004 & 2005 & 2006 & 2007 & 2008 & 2009 & $\begin{array}{l}2010 \\
\text { Proj. }\end{array}$ \\
\hline & \multicolumn{6}{|c|}{ (In percent of GDP) } & \\
\hline Current account balance & -6.2 & -8.3 & -8.4 & -8.0 & -8.6 & -3.0 & -4.6 \\
\hline Goods balance & -1.4 & -2.3 & -1.8 & -1.3 & -1.2 & 1.3 & 1.6 \\
\hline Exports, f.o.b. & 20.5 & 19.7 & 21.0 & 20.8 & 23.9 & 21.7 & 23.0 \\
\hline Imports, f.o.b. & -22.0 & -22.1 & -22.8 & -22.1 & -25.2 & -20.4 & -21.3 \\
\hline Services balance & 1.0 & 0.4 & 0.2 & 0.2 & -0.5 & -0.2 & -0.6 \\
\hline Receipts & 8.3 & 7.8 & 7.6 & 7.2 & 6.9 & 6.5 & 6.3 \\
\hline Payments & -7.2 & -7.4 & -7.3 & -7.0 & -7.4 & -6.7 & -6.9 \\
\hline Income balance & -6.0 & -6.5 & -7.2 & -7.3 & -7.5 & -4.5 & -5.9 \\
\hline Receipts & 1.6 & 1.4 & 1.4 & 2.1 & 1.6 & 1.6 & 1.2 \\
\hline Payments & -7.6 & -7.9 & -8.7 & -9.4 & -9.1 & -6.6 & -7.0 \\
\hline Transfers balance & 0.1 & 0.2 & 0.4 & 0.4 & 0.6 & 0.3 & 0.3 \\
\hline Inflows & 0.9 & 1.1 & 1.2 & 1.1 & 1.3 & 1.0 & 1.0 \\
\hline Outflows & 0.6 & 0.6 & 0.6 & 0.6 & 0.6 & 0.6 & 0.5 \\
\hline Capital and financial account balance & 7.5 & 7.6 & 7.5 & 7.4 & 3.3 & 3.5 & $\ldots$ \\
\hline Capital account (net) & 0.2 & -0.2 & -0.2 & -0.4 & -0.3 & -0.2 & $\ldots$ \\
\hline Financial account (net) & 7.4 & 7.8 & 7.7 & 7.9 & 3.7 & 3.7 & $\ldots$ \\
\hline Direct investment (net) & 2.9 & 2.7 & 4.2 & -0.2 & 4.1 & 0.7 & $\ldots$ \\
\hline Portfolio investment (net) & 6.1 & -0.1 & -1.1 & 8.2 & -6.0 & 3.8 & $\ldots$ \\
\hline Equity securities (net) & -1.5 & -1.1 & -1.1 & -0.5 & 0.3 & -0.7 & $\ldots$ \\
\hline Debt securities (net) & 7.6 & 1.1 & 0.0 & 8.7 & -6.3 & 4.5 & $\ldots$ \\
\hline Other investment (net) & -1.7 & 5.1 & 4.6 & -0.1 & 5.6 & -0.7 & $\ldots$ \\
\hline Assets & -0.2 & 1.6 & -5.3 & -3.7 & 5.3 & -3.9 & $\ldots$ \\
\hline Liabilities & -1.5 & 3.5 & 10.0 & 3.5 & 0.3 & 3.2 & $\ldots$ \\
\hline Net errors and omissions & -1.3 & 0.8 & 0.9 & 0.6 & 5.4 & -0.6 & ... \\
\hline \multirow[t]{2}{*}{ Overall balance } & 0.0 & 0.0 & 0.0 & 0.0 & 0.1 & -0.1 & $\ldots$ \\
\hline & \multicolumn{6}{|c|}{ (Assets and liabilities as of end-December) } & \\
\hline Total external debt & 108.0 & 106.4 & 115.2 & 121.7 & 136.1 & 131.1 & 131.4 \\
\hline Short-term & 52.8 & 56.3 & 60.3 & 67.1 & 64.7 & 58.2 & $\ldots$ \\
\hline Long-term & 55.2 & 50.1 & 55.0 & 54.5 & 71.4 & 72.9 & $\ldots$ \\
\hline Net international investment position & -82.7 & -81.9 & -84.8 & -83.9 & -88.5 & -90.3 & -90.8 \\
\hline Net equity & -16.8 & -11.7 & -10.7 & -8.3 & -3.9 & -6.0 & $\ldots$ \\
\hline \multirow[t]{2}{*}{ Net debt } & -65.9 & -70.2 & -74.0 & -75.6 & -84.6 & -84.3 & $\ldots$ \\
\hline & \multicolumn{6}{|c|}{ (In billions of New Zealand dollars) } & \\
\hline Gross official reserves $1 /$ & 9.7 & 13.1 & 19.9 & 22.3 & 19.1 & 21.6 & 24.0 \\
\hline RBNZ net short position in forex swaps $1 /$ & 1.5 & 2.7 & 10.5 & 10.3 & 5.8 & 10.2 & 12.1 \\
\hline RBNZ net open foreign currency position $1 /$ & 0.0 & 0.0 & -0.1 & 2.5 & 5.0 & 3.5 & 3.3 \\
\hline Gross reserves in months of future imports of g\&s & 3.9 & 5.2 & 8.2 & 8.2 & 8.5 & 9.2 & 9.6 \\
\hline Gross reserves as percent of short-term debt & 12.2 & 14.7 & 19.9 & 18.6 & 16.1 & 20.0 & 22.0 \\
\hline
\end{tabular}

Sources: Data provided by the New Zealand authorities; and Fund staff estimates and projections.

1/ For 2010, actual number for February. 
Table 4. New Zealand: Medium-Term Scenario, 2008-15

\begin{tabular}{|c|c|c|c|c|c|c|c|c|c|}
\hline & \multirow{2}{*}{$\frac{\text { Average }}{1998-2007}$} & \multirow[b]{2}{*}{2008} & \multirow[b]{2}{*}{2009} & \multicolumn{6}{|c|}{ Projections } \\
\hline & & & & 2010 & 2011 & 2012 & 2013 & 2014 & 2015 \\
\hline \multicolumn{10}{|l|}{ Real growth (percent change) } \\
\hline GDP (production basis) & 3.1 & -0.1 & -1.6 & 2.9 & 3.2 & 3.0 & 2.8 & 2.7 & 2.4 \\
\hline GDP (expenditure basis) & 3.3 & -1.0 & -0.3 & 2.9 & 3.2 & 3.0 & 2.8 & 2.7 & 2.4 \\
\hline Final domestic demand & 3.9 & 0.0 & -3.4 & 3.0 & 3.7 & 3.5 & 3.1 & 2.9 & 2.8 \\
\hline Consumption & 3.5 & 0.8 & -0.2 & 2.0 & 2.4 & 2.7 & 2.4 & 2.4 & 2.3 \\
\hline Private consumption & 3.6 & -0.3 & -0.6 & 2.0 & 2.5 & 2.9 & 2.7 & 2.7 & 2.5 \\
\hline Government consumption & 3.2 & 4.8 & 1.5 & 1.9 & 2.0 & 2.0 & 1.6 & 1.6 & 1.6 \\
\hline Fixed investment & 5.4 & -2.6 & -13.5 & 6.9 & 8.2 & 6.0 & 5.2 & 4.3 & 4.3 \\
\hline Private business & 5.8 & 2.2 & -17.8 & 7.4 & 11.0 & 7.4 & 6.9 & 5.4 & 5.4 \\
\hline Private residential & 3.1 & -16.3 & -18.7 & 7.8 & 8.5 & 7.1 & 4.1 & 4.1 & 4.1 \\
\hline Public investment & 8.0 & -3.2 & 4.0 & 4.9 & 0.9 & 1.2 & 1.2 & 1.2 & 1.2 \\
\hline Changes in inventories $1 /$ & 0.0 & 0.4 & -2.5 & 2.0 & 0.0 & 0.0 & 0.0 & 0.0 & 0.0 \\
\hline Exports of goods and services & 4.0 & -1.4 & 0.0 & 2.1 & 5.9 & 5.7 & 4.9 & 5.0 & 4.4 \\
\hline Imports of goods and services & 6.1 & 2.5 & -15.2 & 8.7 & 7.0 & 6.7 & 5.5 & 5.1 & 5.2 \\
\hline Net exports (contribution to growth) & -0.7 & -1.4 & 5.8 & -2.2 & -0.6 & -0.6 & -0.4 & -0.3 & -0.5 \\
\hline \multicolumn{10}{|l|}{ Saving and investment (percent of GDP) } \\
\hline Gross capital formation & 22.6 & 23.3 & 19.2 & 20.9 & 22.0 & 22.6 & 23.0 & 23.2 & 23.5 \\
\hline Fixed investment & 21.8 & 22.4 & 20.1 & 20.5 & 21.6 & 22.2 & 22.6 & 22.9 & 23.2 \\
\hline Changes in inventories & 0.9 & 0.9 & -0.9 & 0.4 & 0.3 & 0.3 & 0.3 & 0.3 & 0.3 \\
\hline National savings $2 /$ & 17.0 & 14.6 & 16.1 & 16.3 & 16.3 & 15.5 & 15.0 & 15.1 & 15.3 \\
\hline Private & 14.2 & 16.6 & 19.7 & 19.9 & 19.5 & 18.1 & 17.0 & 16.1 & 15.9 \\
\hline Public & 2.7 & -2.0 & -3.6 & -3.6 & -3.2 & -2.6 & -2.0 & -1.0 & -0.5 \\
\hline \multicolumn{10}{|l|}{ Inflation and unemployment (percent) } \\
\hline Headline CPI inflation (period average) & 2.2 & 4.0 & 2.1 & 2.1 & 2.5 & 2.7 & 2.7 & 2.3 & 2.0 \\
\hline Headline CPI inflation (end of period) & 2.3 & 3.4 & 2.0 & 2.3 & 2.8 & 2.6 & 2.5 & 2.1 & 2.0 \\
\hline Unemployment rate & 5.2 & 4.2 & 6.2 & 7.2 & 6.6 & 5.9 & 5.4 & 4.7 & 4.4 \\
\hline Output gap (staff estimate) & 0.8 & -0.7 & -3.7 & -2.9 & -1.8 & -1.0 & -0.4 & 0.0 & 0.1 \\
\hline \multicolumn{10}{|l|}{ Government budget (percent of GDP) 3/ } \\
\hline Revenue & 34.2 & 33.9 & 32.2 & 30.1 & 30.2 & 30.2 & 30.6 & 30.7 & 31.3 \\
\hline Expenditure & 32.0 & 31.2 & 34.7 & 34.7 & 34.6 & 33.8 & 33.8 & 33.2 & 33.0 \\
\hline SOE and Crown entity surplus (net) & 0.7 & 0.5 & 0.8 & 0.7 & 0.9 & 0.9 & 0.9 & 0.8 & 0.9 \\
\hline Operating balance $4 /$ & 2.8 & 2.1 & -3.2 & -3.7 & -3.9 & -3.1 & -2.7 & -2.0 & -1.1 \\
\hline Operating balance before gains and losses & 2.6 & 3.1 & -2.1 & -4.0 & -3.4 & -2.9 & -2.6 & -2.1 & -0.9 \\
\hline Residual cash balance & 0.9 & 1.1 & -4.7 & -5.3 & -5.7 & -5.0 & -4.0 & -3.2 & -2.0 \\
\hline Gross Crown debt & 27.6 & 17.2 & 23.5 & 28.4 & 32.3 & 33.0 & 33.5 & 35.1 & 36.3 \\
\hline Net Crown debt excluding NZS Fund & 18.3 & 5.6 & 9.3 & 14.5 & 19.5 & 23.5 & 26.3 & 28.3 & 29.6 \\
\hline Terms of trade (2002 $=100$, goods $\&$ services $)$ & 104.5 & 121.4 & 110.7 & 117.7 & 118.1 & 118.2 & 119.2 & 120.2 & 120.7 \\
\hline Terms of trade (2002=100, goods) & 103.7 & 123.4 & 111.0 & 120.4 & 121.3 & 121.5 & 122.3 & 123.2 & 123.4 \\
\hline Terms of trade (percent change, goods) & 1.8 & 7.4 & -10.1 & 8.5 & 0.7 & 0.2 & 0.6 & 0.7 & 0.1 \\
\hline Export prices & 2.4 & 19.6 & -12.6 & 10.7 & 5.1 & 3.9 & 3.3 & 3.0 & 2.5 \\
\hline Import prices & 0.6 & 11.4 & -2.8 & 2.0 & 4.3 & 3.7 & 2.7 & 2.3 & 2.4 \\
\hline \multicolumn{10}{|l|}{ Balance of payments (percent of GDP) } \\
\hline Current account balance & -5.7 & -8.6 & -3.0 & -4.6 & -5.7 & -7.1 & -8.0 & -8.1 & -8.2 \\
\hline Balance on goods and services & 0.0 & -1.7 & 1.2 & 1.0 & 0.8 & 0.6 & 0.7 & 1.0 & 0.9 \\
\hline Balance on income and transfers & -5.7 & -6.9 & -4.2 & -5.6 & -6.5 & -7.7 & -8.7 & -9.1 & -9.1 \\
\hline Net foreign liabilities (percent of GDP) $5 /$ & 80.5 & 88.5 & 90.3 & 90.8 & 92.4 & 95.9 & 98.9 & 103.7 & 106.8 \\
\hline Gross external debt $5 /$ & 107.9 & 136.1 & 131.1 & 131.4 & 132.8 & 135.5 & 137.8 & 141.6 & 144.1 \\
\hline Partners' GDP growth & 3.7 & 2.3 & -0.7 & 3.5 & 3.8 & 3.8 & 3.7 & 3.7 & 3.6 \\
\hline Partners' import volume growth (goods and services) & 7.1 & 5.0 & -10.8 & 6.6 & 6.4 & 6.5 & 6.2 & 6.0 & 5.9 \\
\hline 90-day Bank Bill Rate & 6.5 & 8.0 & 3.0 & 3.4 & 5.1 & 5.5 & 5.5 & 5.5 & 5.5 \\
\hline 10-year Bond Rate & 6.2 & 6.1 & 5.5 & 6.3 & 6.6 & 6.6 & 6.6 & 6.6 & 6.6 \\
\hline
\end{tabular}

Sources: Data provided by the New Zealand authorities; and Fund staff estimates and projections.

1/ Contribution in percent of GDP.

2/ Fund staff estimates; calculated as residual from gross national investment and external current account balance.

$3 /$ Fiscal years ending June 30 .

4/ Equals revenue less expenditure plus net surplus of state-owned enterprises and Crown entities.

5/ Data for end-December. 
Table 5. New Zealand: Unwinding Crisis-Related Monetary Policy Measures

\begin{tabular}{|c|c|c|}
\hline & Measures Taken & Status of Unwinding \\
\hline Monetary policy rate & $\begin{array}{l}\text { The Official Cash Rate was reduced by } \\
575 \text { basis points since July } 2008 \text { to } \\
2.50 \text { percent in April } 2009 \text {. }\end{array}$ & $\begin{array}{l}\text { The Reserve Bank indicated its } \\
\text { intention to begin removing } \\
\text { policy stimulus around the } \\
\text { middle of } 2010 \text {. }\end{array}$ \\
\hline Liquidity support & $\begin{array}{l}\text { In } 2007-09 \text {, the Reserve Bank expanded } \\
\text { eligible collateral for domestic Reserve } \\
\text { Bank's liquidity operations to include a } \\
\text { broad range of government and private } \\
\text { sector securities, including mortgage- } \\
\text { backed, asset-backed, and corporate } \\
\text { securities. } \\
\text { In May } 2008 \text {, the overnight reverse repo } \\
\text { facility was extended from } 1 \text { day to a } \\
\text { maximum of } 30 \text { days. } \\
\text { In November } 2008 \text {, the Reserve Bank } \\
\text { introduced two new facilities to support } \\
\text { bank liquidity: a term auction facility and } \\
\text { weekly Reserve Bank bill tenders. }\end{array}$ & $\begin{array}{l}\text { From November } 2009 \text { the } \\
\text { maximum term was shortened } \\
\text { to } 1 \text { day. } \\
\text { From November } 2009 \text { the two } \\
\text { facilities were removed. }\end{array}$ \\
\hline $\begin{array}{l}\text { Foreign exchange } \\
\text { swap arrangement }\end{array}$ & $\begin{array}{l}\text { In October } 2008 \text {, the Reserve Bank } \\
\text { established a US } \$ 15 \text { billion swap line } \\
\text { with the U.S. Fed, initially through April } \\
2009 \text { and later extended several times. }\end{array}$ & $\begin{array}{l}\text { The swap line expired on } \\
\text { February 1, } 2010 \text { and was never } \\
\text { used. }\end{array}$ \\
\hline Funding guarantees & $\begin{array}{l}\text { In October } 2008 \text {, the Treasury introduced } \\
\text { a retail deposit guarantee scheme (on an } \\
\text { opt-in basis with a } \$ N Z 1 \text { million cap on } \\
\text { the coverage per depositor per } \\
\text { institution) for two years. Participating } \\
\text { institutions are charged fees, based on } \\
\text { the guaranteed amount and their credit } \\
\text { rating. } \\
\text { In November } 2008 \text {, a guarantee was } \\
\text { offered on banks' wholesale funding, on } \\
\text { an opt-in basis (by institution and by } \\
\text { instrument) for a fee differentiated by the } \\
\text { risk of the issuer and the maturity of the } \\
\text { security-e.g., } 70-180 \text { basis points per } \\
\text { annum for foreign currency issues } \\
\text { depending on issuers' credit rating. }\end{array}$ & $\begin{array}{l}\text { In August } 2009 \text {, the Treasury } \\
\text { announced an extended retail } \\
\text { deposit guarantee scheme from } \\
\text { October } 2010 \text { to end-2011, with } \\
\text { higher fees and a lower } \\
\text { coverage limit of } \\
\text { \$NZ } 0.5 \text { million per depositor } \\
\text { per bank and \$NZ } 0.25 \text { million } \\
\text { per nonbank. } \\
\text { The government will close the } \\
\text { wholesale funding guarantee on } \\
\text { April } 30 \text {, 2010. About } \\
\text { \$NZ 10 billion of debt (about } \\
6 \text { percent of GDP) was issued } \\
\text { under this scheme by end-2009. }\end{array}$ \\
\hline
\end{tabular}


Appendix I. New Zealand: Main Recommendations of the 2009 Article IV Consultation (Consultation Discussions Ended on March 23, 2009)

Fund Recommendations

\section{Policy Actions}

Fiscal policy: Staff advised that, to preserve investor confidence, concrete measures should be laid out in the May 2009 budget to stabilize gross public debt in the medium term and bring it back to around current levels (2025 percent of GDP) in the longer term. The bulk of measures aimed at medium-term consolidation should have an impact in 2010/11 and beyond, when growth is projected to recover. The focus of fiscal consolidation should be on the expenditure side, although revenue measures are likely to be needed to close the gap.

Monetary policy: Staff recommended that, given the weak outlook for growth and inflation, the RBNZ continue to reduce the official cash rate.

Staff suggested that the authorities consider alternative instruments, such as quantitative easing, in the unlikely event that such measures are needed.

Financial sector policy: Staff recommended that, given the downside risks to the outlook, banks be required to undertake extreme stress tests and increase their capital if needed, and supported the RBNZ's plan to press ahead with its proposed prudential liquidity rules to strengthen the liquidity of the banking system.
The 2009/10 budget planed to reduce the deficits gradually through expenditure restraint and fiscal drag, with a return to surpluses projected by 2017 . Net public debt is projected by the authorities to peak at 30 percent of GDP in 2015 and gradually decline to below 20 percent of GDP by 2024. Gross public debt is projected to fall to just over 20 percent of GDP by 2024 . However, the adjustment is backloaded and concrete measures to reach the medium targets remain to be defined.

The official cash rate was cut further to 2.5 percent at end-April 2009 (the lowest since its introduction in 1999) and then kept unchanged as the economy emerged from recession in mid-2009.

The economic situation improved, starting in mid-2009, so no further actions were taken in addition to the measures taken by early 2009, which broadened eligible collateral for the RBNZ's liquidity operations and introduced two new facilities to support bank liquidity.

A joint stress-testing exercise with Australian supervisors is underway, and the banking sector has remained well capitalized. The RBNZ introduced two liquidity mismatch ratios and a core funding ratio (which came into force in April 2010)

to increase banks' liquidity buffers and reduce reliance on short-term offshore funding. 
Appendix II. New Zealand: External Debt Sustainability: Bound Tests 1/ (Gross external debt in percent of GDP)
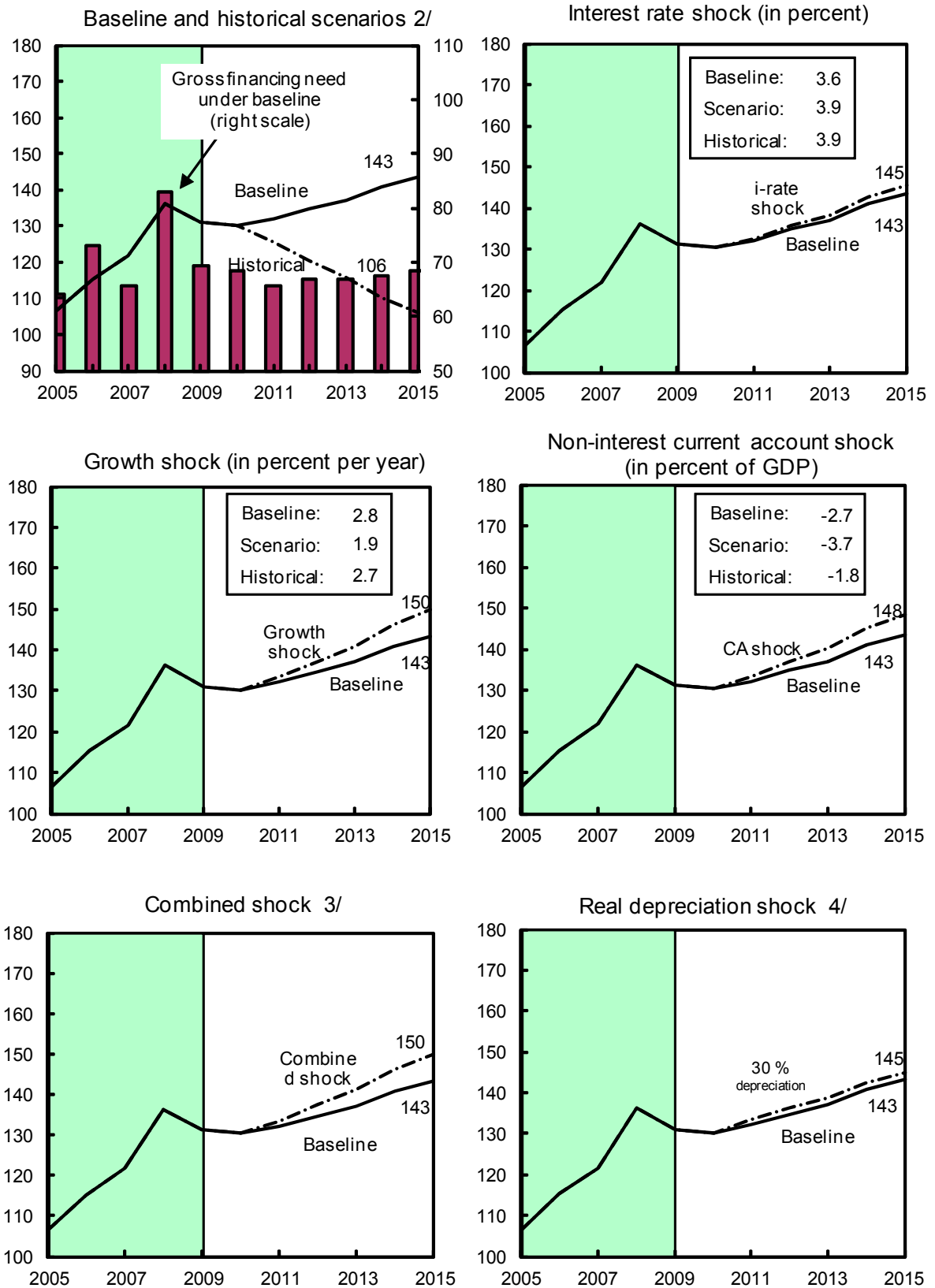

Sources: Fund staff estimates and projections.

1/Shaded areas represent actual data. Individual shocks are permanent one-half standard deviation shocks. Figures in the boxes represent average projections for the respective variables in the baseline and scenario being presented. Ten-year historical average for the variable is also shown. 2/The historical scenario assumes that real GDP growth, inflation, current account deficit, and nominal interest rate are equal to ten-year averages from 2010 onward.

$3 /$ Permanent $1 / 4$ standard deviation shocks applied to real interest rate, growth rate, and current account balance.

4/This scenario assumes foreign exchange hedging covers 91 percent of foreign currency debt, consistent with the findings of hedging surveys conducted by Statistics New Zealand.

\section{CInternational Monetary Fund. Not for Redistribution}


INTERNATIONAL MONETARY FUND

NEW ZEALAND

Staff Report for the 2010 Article IV Consultation-Informational Annex

Prepared by the Asia and Pacific Department

April 27, 2010

Contents

Page

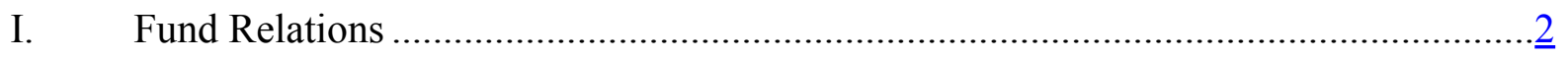

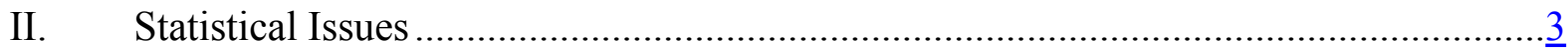




\section{ANNEX I. NeW ZeALAND: Fund Relations}

(As of March 31, 2010)

I. Membership Status: Joined: August 31, 1961; Article VIII

II. General Resources Account:

SDR Million

Percent Quota

Quota

894.60

100.00

Fund Holdings of Currency

720.78

80.57

Reserve position in Fund

173.84

19.43

III. SDR Department:

SDR Million

853.76

Percent Allocation

Net cumulative allocation

854.68

100.00

Holdings

100.11

IV. Outstanding Purchases and Loans: None

V. Financial Arrangements: None

VI. Projected Obligations to Fund: None

VII. Exchange Arrangement:

New Zealand accepted the obligations of Article VIII on August 5, 1982. The

New Zealand dollar has floated independently since March 1985 and the de facto exchange rate arrangement is free floating. New Zealand maintains an exchange system that is free of restrictions on the making of payments and transfers for current international transactions, other than restrictions notified to the Fund in accordance with Decision No. 144-(52/51).

VIII. Article IV Consultation:

New Zealand is on the 12-month consultation cycle. The 2009 Article IV consultation discussions were held during March 13-23, 2009; the Executive Board discussed the staff report (IMF Country Report No. 09/145) and concluded the consultation on May 6, 2009.

IX. FSAP Participation and ROSCs:

FSAP mission took place during October 30-November 18, 2003. The FSSA and the Detailed Assessments of Observance of IOSCO Objectives and Principles of Securities Regulation and FATF Recommendations for Anti-Money Laundering and Combating the Financing of Terrorism were published under Country Reports No. 04/126, No. 04/417, and No. 05/284, respectively.

X. Technical Assistance:

None

XI. Resident Representative/Advisor: None 


\section{ANNEX II. NeW ZEALAND: Statistical IsSueS}

Data provision is adequate for surveillance. The authorities are continuing to enhance data quality and expand the range of data available, including a project led by the Reserve Bank of New Zealand to publish data consistent with the Monetary and Financial Statistics Manual 2000 (MFSM 2000). Given New Zealand's high level of external indebtedness, the publication of up to date institutional sector and flow of funds accounts would be an important addition to the current suite of statistics.

Table of Common Indicators Required for Surveillance

(As of April 14, 2010)

\begin{tabular}{|c|c|c|c|c|c|}
\hline & $\begin{array}{c}\text { Date of } \\
\text { latest } \\
\text { observation }\end{array}$ & $\begin{array}{l}\text { Date } \\
\text { received }\end{array}$ & $\begin{array}{c}\text { Frequency } \\
\text { of } \\
\text { Data }^{7} \\
\end{array}$ & $\begin{array}{l}\text { Frequency } \\
\text { of } \\
\text { Reporting }^{7}\end{array}$ & $\begin{array}{l}\text { Frequency } \\
\text { of } \\
\text { Publication }^{7}\end{array}$ \\
\hline Exchange Rates & $4 / 14 / 10$ & $4 / 14 / 10$ & $\mathrm{D}$ & $\mathrm{D}$ & $\mathrm{D}$ \\
\hline $\begin{array}{l}\text { International Reserve Assets and Reserve } \\
\text { Liabilities of the Monetary Authorities }^{1}\end{array}$ & $2 / 10$ & $3 / 30 / 10$ & M & M & M \\
\hline Reserve/Base Money & $2 / 10$ & $3 / 30 / 10$ & M & M & M \\
\hline Broad Money & $2 / 10$ & $3 / 30 / 10$ & M & M & M \\
\hline Central Bank Balance Sheet & $2 / 10$ & $3 / 30 / 10$ & M & M & M \\
\hline $\begin{array}{l}\text { Consolidated Balance Sheet of the Banking } \\
\text { System }\end{array}$ & $2 / 10$ & $3 / 30 / 10$ & M & M & M \\
\hline Interest Rates ${ }^{2}$ & $4 / 14 / 10$ & $4 / 14 / 10$ & $\mathrm{D}$ & $\mathrm{D}$ & $\mathrm{D}$ \\
\hline Consumer Price Index & Q4 2009 & $1 / 20 / 10$ & Q & Q & Q \\
\hline $\begin{array}{l}\text { Revenue, Expenditure, Balance and } \\
\text { Composition of Financing }^{3}-\text { General } \\
\text { Government }^{4}\end{array}$ & $2008 / 09$ & $12 / 15 / 09$ & A & A & A \\
\hline $\begin{array}{l}\text { Revenue, Expenditure, Balance and } \\
\text { Composition of Financing }{ }^{3}-\text { Central Government }\end{array}$ & $2 / 10$ & $4 / 9 / 10$ & M & M & M \\
\hline $\begin{array}{l}\text { Stocks of Central Government and Central } \\
\text { Government-Guaranteed Debt }\end{array}$ & $2 / 10$ & $4 / 9 / 10$ & M & M & M \\
\hline External Current Account Balance & Q4 2009 & $3 / 24 / 10$ & Q & Q & Q \\
\hline Exports and Imports of Goods and Services & Q4 2009 & $3 / 24 / 10$ & Q & Q & Q \\
\hline GDP/GNP & Q4 2009 & $3 / 25 / 10$ & Q & Q & Q \\
\hline Gross External Debt & Q4 2009 & $3 / 24 / 10$ & Q & Q & Q \\
\hline International Investment Position ${ }^{6}$ & Q4 2009 & $3 / 24 / 10$ & $Q$ & Q & Q \\
\hline
\end{tabular}

${ }^{1}$ Includes reserve assets pledged or otherwise encumbered as well as net derivative positions.

${ }^{2}$ Both market-based and officially determined, including discount rates, money market rates, rates on treasury bills, notes, and bonds.

${ }^{3}$ Foreign, domestic bank, and domestic non-bank financing.

${ }^{4}$ The general government consists of the central government (including budgetary, extra budgetary, and social security funds) and state and local governments.

${ }^{5}$ Including currency and maturity composition.

${ }^{6}$ Includes external gross financial asset and liability positions vis-à-vis nonresidents.

${ }^{7}$ Daily (D), Weekly (W), Monthly (M), Quarterly (Q), Annually (A), Irregular (I); Not Available (NA). 


\section{INTERNATIONAL MONETARY FUND}

\section{Public Information Notice}

Public Information Notice (PIN) No. 10/64

FOR IMMEDIATE RELEASE

May 26, 2010
International Monetary Fund

$70019^{\text {th }}$ Street, NW

Washington, D. C. 20431 USA

\section{IMF Executive Board Concludes 2010 Article IV Consultation with New Zealand}

On May 12, 2010, the Executive Board of the International Monetary Fund (IMF) concluded the Article IV consultation with New Zealand. ${ }^{1}$

\section{Background}

New Zealand rode out the global crisis better than most advanced economies, thanks to strong demand from fast-growing Asian markets and the robust Australian economy, a flexible exchange rate, the absence of a banking crisis, and significant and effective policy easing. Nevertheless, the crisis highlighted long-standing vulnerabilities due to high household and external debt.

Led by domestic demand, the economy emerged from the recession in mid-2009. A large output gap contained growth in labor costs and eased inflationary pressures, with the annual CPI inflation falling from the peaks of $4-5$ percent in 2008 to about 2 percent in early 2009 . After cutting the official cash rate (OCR) by 575 basis points from mid-2008 to early 2009 , the Reserve Bank of New Zealand (RBNZ) has kept it at a historical low of $2 \frac{1}{2}$ percent. The strong pre-crisis fiscal position also enabled the delivery of a large fiscal easing that was in train prior to the crisis, equivalent to almost 6 percent of GDP spread over the two years to June 2010.

\footnotetext{
${ }^{1}$ Under Article IV of the IMF's Articles of Agreement, the IMF holds bilateral discussions with members, usually every year. A staff team visits the country, collects economic and financial information, and discusses with officials the country's economic developments and policies. On return to headquarters, the staff prepares a report, which forms the basis for discussion by the Executive Board. At the conclusion of the discussion, the Managing Director, as Chairman of the Board, summarizes the views of Executive Directors, and this summary is transmitted to the country's authorities. An explanation of any qualifiers used in summings up can be found here: http://www.imf.org/external/np/sec/misc/qualifiers.htm.
} 
The current account deficit narrowed sharply in 2009 to 3 percent of GDP, as both trade and income balances improved. Private capital inflows continued to finance the deficit, and net foreign liabilities increased marginally to 90 percent of GDP. The exchange rate depreciated sharply at the onset of the crisis, but has appreciated by over 20 percent since early 2009 , reflecting a recovery in commodity prices and global risk appetite, and a widening of interest rate differentials.

Banks remain sound but faced some funding difficulties during the crisis. In response, the government introduced a temporary wholesale funding guarantee that helped banks obtain term funding of about $\$ N Z 10$ billion until they were able to access the market directly in late 2009. Banks remain exposed to highly-indebted households and house prices appear overvalued.

A gradual recovery is expected to continue, with growth projected at 3 percent in 2010-11. The outlook is subject to downside risks related to the pace of global recovery and borrowing costs for countries with high external debt, such as New Zealand.

\section{Executive Board Assessment}

Executive Directors commended the authorities for their decisive policy response, which helped cushion the impact of the global crisis on the New Zealand economy and is supporting a gradual economic recovery. Directors noted that the fiscal and monetary policy frameworks, including the flexible exchange rate regime, have served New Zealand well during the crisis. Key policy challenges are to lift sustainable economic growth and reduce the vulnerabilities associated with a deteriorated fiscal position and high private external debt.

Directors concurred that New Zealand's strong fiscal position has appropriately enabled a sizeable stimulus to cushion the impact of the crisis. At the same time, they noted that the fiscal easing, which was already underway prior to the crisis, has worsened New Zealand's mediumterm fiscal outlook. Directors therefore welcomed the government's commitment to limit the increase in public debt, including the plan to use any revenue over-performance to reduce debt. Many Directors felt that, unless downside risks to growth materialize, shifting the macroeconomic policy mix towards faster fiscal consolidation, focused on spending reforms, would merit consideration. It would relieve pressure on monetary policy and the exchange rate, limit the increase in the current account deficit, create fiscal space to deal with future shocks, and reduce the risk of a recurrence of external funding problems.

Directors considered the current accommodative monetary stance as appropriate. They supported a measured withdrawal of the stimulus once the recovery is well established, given that spare capacity is expected to persist over the next few years, helping to keep inflation within the 1-3 percent target range. If downside risks to inflation materialized, there could be room to loosen monetary policy. Directors observed that the inflation-targeting framework 
performed well during the global crisis and saw no clear net benefits to increasing the inflation target.

Directors noted that the exchange rate is overvalued from a medium-term perspective, while recognizing the uncertainty surrounding the estimates. The exchange rate would need to be significantly lower for an extended period of time for New Zealand's external liabilities position to be materially reduced.

Directors noted that New Zealand's financial sector has remained resilient through the global crisis. Banks are well capitalized and nonperforming loans, although increasing, are low. Directors encouraged the authorities to continue to be vigilant to risks arising from banks' exposure to short-term external and household debt and the possible impact of a correction in house prices. They welcomed the closer collaboration with the Australian authorities on crisis management and stress tests, and recommended that banks' capital and provisioning be strengthened if these tests suggest the need for additional buffers.

Directors noted that prudential and structural reforms would help reduce external vulnerabilities. They welcomed the introduction of a prudential liquidity policy, including a core funding ratio, which should reduce banks' reliance on short-term external funding. Directors also underscored the importance of structural reforms to raise productivity and labor force participation, including tax and benefit reform, to help lift potential growth and export capacity, and support economic rebalancing, thereby reducing vulnerabilities related to external debt.

Public Information Notices (PINs) form part of the IMF's efforts to promote transparency of the IMF's views and analysis of economic developments and policies. With the consent of the country (or countries) concerned, PINs are issued after Executive Board discussions of Article IV consultations with member countries, of its surveillance of developments at the regional level, of post-program monitoring, and of ex post assessments of member countries with longer-term program engagements. PINs are also issued after Executive Board discussions of general policy matters, unless otherwise decided by the Executive Board in a particular case. The staff report (use the free Adobe Acrobat Reader to view this pdf file) for the 2010 Article IV Consultation with New Zealand is also available. 
New Zealand: Selected Economic Indicators

\begin{tabular}{|c|c|c|c|c|c|c|}
\hline & 2006 & 2007 & 2008 & 2009 & $\begin{array}{l}\text { Proj. } \\
2010 \\
\end{array}$ & $\begin{array}{l}\text { Proj. } \\
2011 \\
\end{array}$ \\
\hline \multicolumn{7}{|l|}{ Real economy (percent change) } \\
\hline GDP (production basis) & 1.0 & 2.8 & -0.1 & -1.6 & 2.9 & 3.2 \\
\hline Final domestic demand & 1.9 & 4.3 & 0.0 & -3.4 & 3.0 & 3.7 \\
\hline Exports of goods and services & 1.7 & 3.8 & -1.4 & 0.0 & 2.1 & 5.9 \\
\hline Imports of goods and services & -2.5 & 8.7 & 2.5 & -15.2 & 8.7 & 7.0 \\
\hline Headline CPI inflation (end of period) & 2.7 & 3.2 & 3.4 & 2.0 & 2.3 & 2.8 \\
\hline Unemployment rate (in percent) & 3.8 & 3.7 & 4.2 & 6.2 & 7.2 & 6.6 \\
\hline National saving (in percent of GDP) $1 /$ & 14.9 & 15.9 & 14.6 & 16.1 & 16.3 & 16.3 \\
\hline Investment (in percent of GDP) & 23.4 & 23.9 & 23.3 & 19.2 & 20.9 & 22.0 \\
\hline \multicolumn{7}{|l|}{ Government budget (in percent of GDP) 2/ } \\
\hline Revenue & 37.0 & 33.9 & 33.9 & 32.2 & 30.1 & 30.2 \\
\hline Expenditure & 34.2 & 31.5 & 31.2 & 34.7 & 34.7 & 34.6 \\
\hline Operating balance before gains and losses & 4.6 & 3.4 & 3.1 & -2.1 & -4.0 & -3.4 \\
\hline Net Crown debt excluding NZS Fund & 10.2 & 7.7 & 5.6 & 9.3 & 14.5 & 19.5 \\
\hline \multicolumn{7}{|l|}{ Interest rates (period average) } \\
\hline Interest rate (90-day, in percent) $3 /$ & 7.5 & 8.3 & 8.0 & 3.0 & 2.7 & $\cdots$ \\
\hline Government bond yield ( 10 -year, in percent) $3 /$ & 5.8 & 6.3 & 6.1 & 5.5 & 5.9 & .. \\
\hline \multicolumn{7}{|l|}{ Money and credit (end of period) } \\
\hline M3, resident (change in percent) $4 /$ & 11.3 & 11.1 & 10.4 & -0.6 & -3.6 & $\cdots$ \\
\hline Private domestic credit (change in percent) 4/ & 12.4 & 12.8 & 7.4 & 0.9 & 0.2 & $\ldots$ \\
\hline \multicolumn{7}{|l|}{ Balance of payments (in percent of GDP) } \\
\hline Current account balance & -8.4 & -8.0 & -8.6 & -3.0 & -4.6 & -5.7 \\
\hline Trade balance (goods) & -1.8 & -1.3 & -1.2 & 1.3 & 1.6 & 1.6 \\
\hline Terms of trade (change in percent) & 0.0 & 6.0 & 7.4 & -10.1 & 8.5 & 0.7 \\
\hline \multicolumn{7}{|l|}{ External assets and liabilities (in percent of GDP) } \\
\hline Official reserves (NZ\$ billions) 4/ & 19.9 & 22.3 & 19.1 & 21.6 & 24.0 & $\ldots$ \\
\hline Gross external debt & 115.2 & 121.7 & 136.1 & 131.1 & 131.4 & 132.8 \\
\hline Net international investment position & -84.8 & -83.9 & -88.5 & -90.3 & -90.8 & -92.4 \\
\hline \multicolumn{7}{|l|}{ Exchange rate (period average) } \\
\hline US $\$ / \$ N Z 3 /$ & 0.65 & 0.74 & 0.71 & 0.63 & 0.71 & $\ldots$ \\
\hline Trade-weighted index (June $1979=100) 3 /$ & 65.4 & 70.9 & 65.7 & 60.2 & 64.8 & $\ldots$ \\
\hline Nominal effective exchange rate $5 /$ & 123.8 & 133.0 & 124.1 & 113.6 & 123.1 & $\ldots$ \\
\hline Real effective exchange rate 5/ & 128.2 & 137.8 & 128.9 & 120.5 & 130.9 & $\ldots$ \\
\hline
\end{tabular}

Sources: Data provided by the New Zealand authorities; and IMF staff estimates and projections.

1/ Based on national accounts data.

2/ Fiscal years ending June 30.

3/ Data for 2010 are for January-March.

4/ Data for 2010 are for February.

5/ IMF Information Notice System index $(2000=100)$. Data for 2010 are as of February. 